\title{
Hydrogels and Dentin-Pulp Complex Regeneration: From the Benchtop to Clinical Translation
}

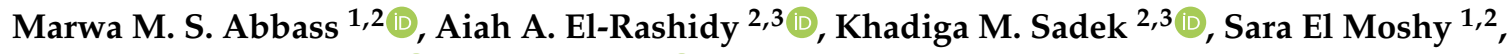 \\ Israa Ahmed Radwan ${ }^{1,2}{ }^{-}$, Dina Rady ${ }^{1,2}{ }^{-0}$, Christof E. Dörfer ${ }^{4}$ and \\ Karim M. Fawzy El-Sayed 2,4,5,* \\ 1 Oral Biology Department, Faculty of Dentistry, Cairo University, Cairo 11562, Egypt; \\ marwa.magdy@dentistry.cu.edu.eg (M.M.S.A.); sarah.mahmoud@dentistry.cu.edu.eg (S.E.M.); \\ esraa.ahmed@dentistry.cu.edu.eg (I.A.R.); dina.radi@dentistry.cu.edu.eg (D.R.) \\ 2 Stem Cells and Tissue Engineering Research Group, Faculty of Dentistry, Cairo University, \\ Cairo 11562, Egypt; aiah.abdelwahab@dentistry.cu.edu.eg (A.A.E.-R.); \\ khadiga.sadek@dentistry.cu.edu.eg (K.M.S.) \\ 3 Biomaterials Department, Faculty of Dentistry, Cairo University, Cairo 11562, Egypt \\ 4 Clinic for Conservative Dentistry and Periodontology, School of Dental Medicine, \\ Christian Albrechts University, 24105 Kiel, Germany; doerfer@konspar.uni-kiel.de \\ 5 Oral Medicine and Periodontology Department, Faculty of Dentistry, Cairo University, Cairo 11562, Egypt \\ * Correspondence: karim.fawzy@gmail.com
}

Received: 22 October 2020; Accepted: 10 November 2020; Published: 9 December 2020

check for updates

\begin{abstract}
Dentin-pulp complex is a term which refers to the dental pulp (DP) surrounded by dentin along its peripheries. Dentin and dental pulp are highly specialized tissues, which can be affected by various insults, primarily by dental caries. Regeneration of the dentin-pulp complex is of paramount importance to regain tooth vitality. The regenerative endodontic procedure (REP) is a relatively current approach, which aims to regenerate the dentin-pulp complex through stimulating the differentiation of resident or transplanted stem/progenitor cells. Hydrogel-based scaffolds are a unique category of three dimensional polymeric networks with high water content. They are hydrophilic, biocompatible, with tunable degradation patterns and mechanical properties, in addition to the ability to be loaded with various bioactive molecules. Furthermore, hydrogels have a considerable degree of flexibility and elasticity, mimicking the cell extracellular matrix (ECM), particularly that of the DP. The current review presents how for dentin-pulp complex regeneration, the application of injectable hydrogels combined with stem/progenitor cells could represent a promising approach. According to the source of the polymeric chain forming the hydrogel, they can be classified into natural, synthetic or hybrid hydrogels, combining natural and synthetic ones. Natural polymers are bioactive, highly biocompatible, and biodegradable by naturally occurring enzymes or via hydrolysis. On the other hand, synthetic polymers offer tunable mechanical properties, thermostability and durability as compared to natural hydrogels. Hybrid hydrogels combine the benefits of synthetic and natural polymers. Hydrogels can be biofunctionalized with cell-binding sequences as arginine-glycine-aspartic acid (RGD), can be used for local delivery of bioactive molecules and cellularized with stem cells for dentin-pulp regeneration. Formulating a hydrogel scaffold material fulfilling the required criteria in regenerative endodontics is still an area of active research, which shows promising potential for replacing conventional endodontic treatments in the near future.
\end{abstract}

Keywords: hydrogels; polymers; stem cells; tissue engineering; dental; regeneration 


\section{Introduction}

Regeneration of damaged/lost biological tissues represents a major challenge for clinicians and researchers worldwide. The extracellular matrix (ECM) of these biological tissues is composed of a tangled mesh of fibrous proteins and glycosaminoglycans, which provides anchorage to the cells and regulates cellular behavior and interaction via various signals. ECM is synthesized and continuously remodeled by its resident cells [1]. Natural and synthetic biomaterials that can mimic ECM to reproduce all its characteristics are still not available [2]. However, currently the use of natural scaffolds, including polymeric scaffolds, ceramic scaffolds or combinations of different scaffold types loaded with suitable cells and signaling molecules is considered the classical strategy in tissue engineering approaches.

Dentin-pulp complex is a term referring to the dental pulp surrounded by dentin along its peripheries. It reflects the close anatomical and functional relationship that exists between the dentin and dental pulp [3]. Dentin and dental pulp are highly specialized tissues, where the dental pulp is a vascular connective tissue responsible for the maintenance of tooth vitality, while dentin is the protective tissue for this vital pulp [4-6]. Maintaining dentin/pulp integrity and vitality are of importance for all dental practitioners and researchers [7]. Dental caries, among other insults to the tooth structure, can result in irreversible pulpal damage with devastating effects. Regeneration of the dentin-pulp complex to regain tooth vitality remains to be of paramount importance.

Dentin is composed of an inorganic (hydroxyapatite) and organic matrix, comprising mainly collagen and non-collagenous proteins. Non-collagenous proteins include phosphorylated proteins, members of the small integrin-binding ligand N-linked glycoproteins (SIBLINGs) family, including transient dentin sialophosphoprotein (DSPP), which is cleaved after secretion into dentin sialoprotein (DSP) and dentin phosphoprotein (DPP), in addition to dentin matrix protein-1 (DMP-1), bone sialoprotein (BSP) and osteopontin (OP). Non-collagenous proteins also include non-phosphorylated proteins, including osteocalcin (OCN) and small leucine-rich proteoglycans. Non-collagenous proteins have cell-binding sequences, arginine-glycine-aspartic acid (RGD) domains, and can act as signaling molecules in addition to their role in controlling dentin mineralization and regulating hydroxyapatite crystal formation [8]. Three types of dentin can be distinguished: primary dentin, that is formed before tooth eruption, secondary dentin, formed after completion of root formation and tertiary dentin, formed in response to various stimuli, reflecting the dentin-pulp complex's regenerative capacity. According to the urgency of the stimulus, tertiary dentin can be classified into reactionary dentin formed by existing odontoblasts in response to mild stimulus and reparative dentin formed by odontoblasts-like cells recruited from pulp progenitor cells in response to more severe stimuli [9].

The dental pulp, on the other hand, is a loose connective tissue occupying the center of the tooth. It is a home to a variety of cells, including fibroblasts, odontoblasts, inflammatory and immune system cells in addition to dental pulp stem cells (DPSCs), which reside in perivascular areas and the cell-rich zone of Hohl $[9,10]$. Dental pulp is also characterized by its extensive neuro-vascular networks enabling it to perform its functions, which should be duplicated for successful pulpal regeneration [11].

Odontoblasts are specialized cells responsible for the formation of dentin. They originate through the differentiation of ecto-mesenchymal cells of the dental papilla triggered by a series of complex epithelial mesenchymal interactions [3,12]. The process of odontoblastic differentiation is closely governed by bioactive molecules, which can promote cell proliferation, migration and differentiation. Various growth factors, including transforming growth factor-beta (TGF- $\beta$ ), bone morphogenic proteins (BMP), epidermal growth factor, fibroblast growth factor 2 (FGF2), growth differentiation factor 11, platelet-derived growth factor (PDGF), hepatocyte growth factor and insulin-like growth factors (IGF), have been implicated in odontoblastic differentiation during early stages of tooth development [3]. Once differentiated, odontoblasts can in turn secrete bioactive molecules including TGF- $\beta$, BMPs, insulin-like growth factor (IGF-1) and IGF-2, FGF-2 and angiogenic factors. Those bioactive molecules become entrapped within the dentin matrix and can be released upon matrix degradation into the pulp tissues to undertake a role in the regeneration process $[9,13]$. Odontoblasts' response to various stimuli, 
such as dental caries or cavity preparation, is governed by the intensity of the inflammatory reaction. Low-grade inflammation or stimulus induce dentin regeneration through bioactive molecules released from the dentin matrix and pulpal cells, while severe stimuli and inflammation induce cellular death and impair dentin regeneration [14].

For damaged pulp tissue, direct and indirect pulp capping are considered to be the first line of treatment to maintain the pulpal tissue vitality, while the endodontic treatment, relying on three-dimensional shaping, cleaning and filling of the pulpal soft tissue space within the tooth via a biocompatible inert material, leads to loss of pulp vitality with its consequences on the integrity of the tooth structure. In young permanent teeth, such a loss of vitality may affect the tooth maturation and its apexogenesis, which renders the regeneration of the dentin-pulp complex through a different tissue engineering approach a major concern for researchers. On the other hand, dentin-pulp complex regeneration through regenerative endodontic procedure (REP) $[15,16]$ or revascularization relies on stimulating the differentiation of resident stem/progenitor cells [17]. REP involves the induction of intracanal bleeding and the formation of a blood clot, which act as a scaffold for stem/progenitor cells from the apical dental papilla (SCAP) migration and differentiation for regeneration [18].

For successful REP, two prerequisites are needed to achieve pulp regeneration; efficient root canal disinfection and proper size of the apical foramen [19]. Thus, the effect of different root canal irrigants used on cellular behavior and differentiation is crucial. Sodium hypochlorite $(\mathrm{NaOCl})$ has a potent anti-microbial and proteolytic activity, however, it could cause a severe inflammatory response and a damage to vital tissues. Furthermore, $\mathrm{NaOCl}$ cannot remove the smear layer on the dentin surface, which may make the dentin surface unrecognizable to the seeded cells and hinder cellular interaction [20]. Ethylenediaminetetraacetic acid (EDTA) on the other hand has a chelating activity and is used as a final rinse for smear layer removal, or in combination with $\mathrm{NaOCl}$ and chlorhexidine gluconate (CHX) solutions. The addition of EDTA to other rinsing solutions can increase the viability of DPSCs, and induce DPSCs cell attachment and odontoblastic/osteoblastic differentiation [21]. Additionally, EDTA can remove the smear layer and stimulate the release of pro-angiogenic GFs in the dentin matrix, including TGF- $\beta$, VEGF, FGF-2, PDGF, and BMP-2, through the demineralization of the superficial dentin layer $[20,22]$.

Dentin-pulp complex regeneration could also include approaches for replacing/repairing the damaged pulp tissues through tissue engineering approaches. Different tissue engineering approaches depend basically on the combination of three components: cells, bioactive molecules and scaffolds. Stem/progenitor cells investigated in the field of dentin-pulp complex regeneration include stem/progenitor cells of exfoliated deciduous teeth (SHED), periodontal ligament stem/progenitor cells (PDLSCs), DPSCs, SCAP, and dental follicle stem/progenitor cells [23]. BMP, vascular endothelial growth factor (VEGF), FGF-2 and TGF are the principal morphogens used frequently in conjunction with dental stem/progenitor cells to induce a variety of cellular activities and induce various tissue structures, even when used at very low concentrations [1]. VEGF and FGF were shown to enhance angiogenesis and neovascularization in severed human dental pulps [24], while BMPs are suggested to induce new dentin formation [25]. Scaffolds used for dentin-pulp complex regeneration include polymeric, ceramics and bioactive glass $[7,11]$, whereby the scaffold carries bioactive molecules that can home, stimulate and promote differentiation of tissue resident stem/progenitor cells [26]. Cell-free scaffolds were further suggested as an alternative for dentin-pulp complex regeneration.

Recently, hydrogel-based scaffolds were introduced in the field of tissue engineering. They are a unique category of three-dimensional (3D) polymeric networks with water as the liquid component. Their hydrophilic nature renders them able to retain high water content and biological fluids, as well as diffusion of nutrients through their structure. In addition to their biocompatibility, their expected degradation pattern and their adjustable mechanical properties, they can maintain their network integrity and thus do not dissolve in high water concentrations due to their crosslinking structure. Furthermore, hydrogels have a considerable degree of flexibility and elasticity similar to a natural ECM, providing the essential cell support needed during tissue regeneration. Thus, they are considered an 
optimal choice for many tissue engineering applications due to such unique characteristics, in addition to their gelatinous structure and their ability to be loaded with different drugs, making them successful drug delivery system [7,27-29] (Figure 1).

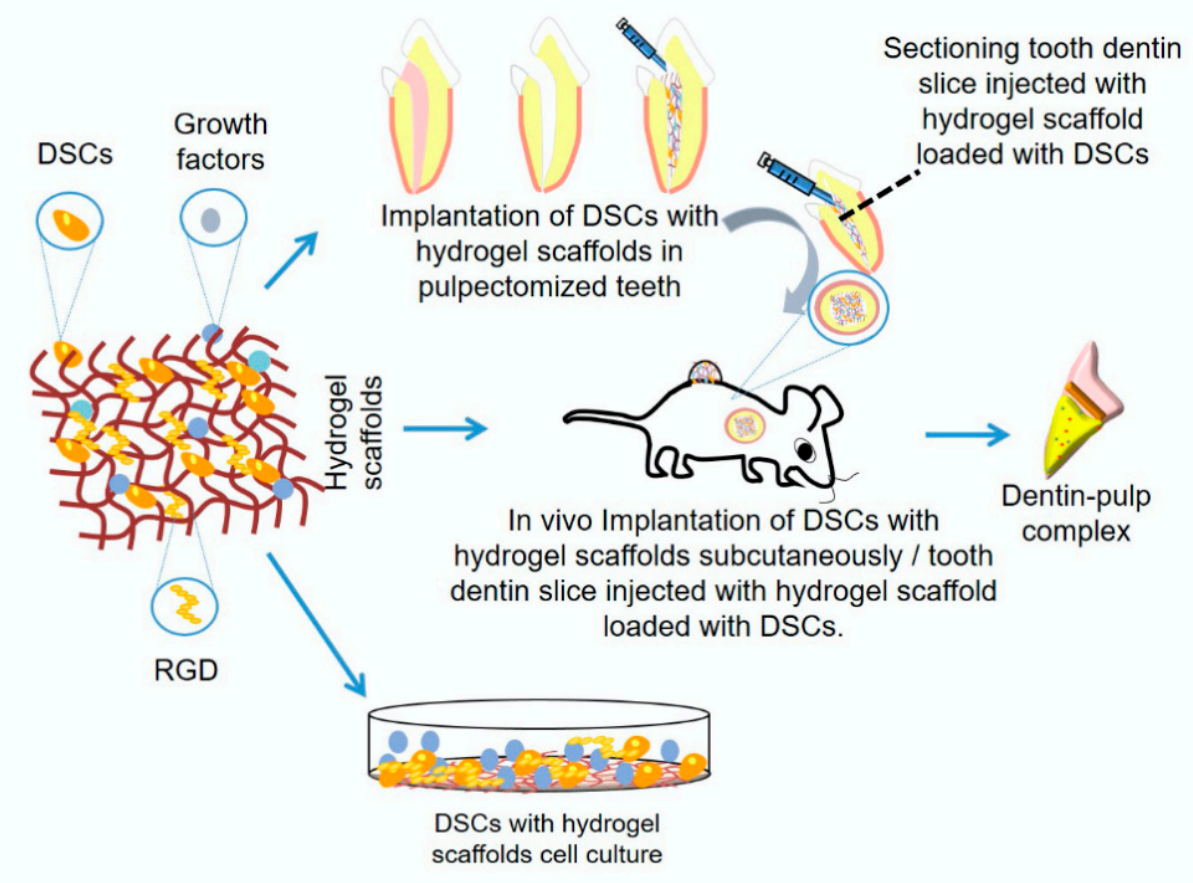

Figure 1. Schematic diagram showing hydrogel scaffold for dentin/pulp regeneration research methods.

Hydrogel systems can be classified according to their polymeric composition, origin, physical appearance, configuration, type of crosslinking or electrical charge [30]. According to the source of the polymeric chain forming the hydrogel, they can be classified into natural, synthetic or hybrid hydrogels. Hydrogels could be made essentially from one type of polymer, natural or synthetic, or a combination of them, or by modifying the polymer through crosslinking agents. The natural polymers forming hydrogels are mainly collagen, fibrin, chitosan, alginate or hyaluronic acid, while the synthetic ones are the polylactic acid (PLA)-based hydrogels, polydimethylsiloxane, polyethylene glycol (PEG), or self-assembling peptides. However, although natural polymers-based hydrogels are characterized by their ability to mimic natural tissues, they are also liable to be easily permanently damaged due to their poor mechanical properties. On the contrary, the synthetic ones have considerably higher mechanical properties and tunable physicochemical properties but lack natural tissue resemblance [29].

Depending on the crosslinking method, hydrogels are either physically or chemically crosslinked [31,32]. Crosslinking is essential for hydrogel solidification to attain adequate mechanical properties, prevent its premature dissolution in an aqueous environment, increase its resistance to heat or wear and to create a network structure [33,34]. Physically crosslinked hydrogels are formed by self-assembly following a change in environmental conditions, including temperature, ionic concentration or $\mathrm{pH}$ value [35]. Physically crosslinked hydrogels are stabilized via physical interaction between polymeric chains, without the use of any chemical crosslinkers or initiators, while chemically crosslinked hydrogels are stabilized by covalent bonding between polymeric chains [33].

\section{Requirements of Ideal Hydrogel Scaffold for Dentin-Pulp Complex Regeneration}

The ideal materials used for dentin-pulp complex regeneration (Figure 2) should be biocompatible and clinically applicable. They should be sterilizable, easy to use and apply, have the ability to be stored 
at clinical settings, with a reasonable shelf-life, injectable to adapt to canal morphology, have short setting times and be without any discomfort to the patient [36,37]. Scaffolds should also be cost-effective to allow mass production for clinical translation [38].

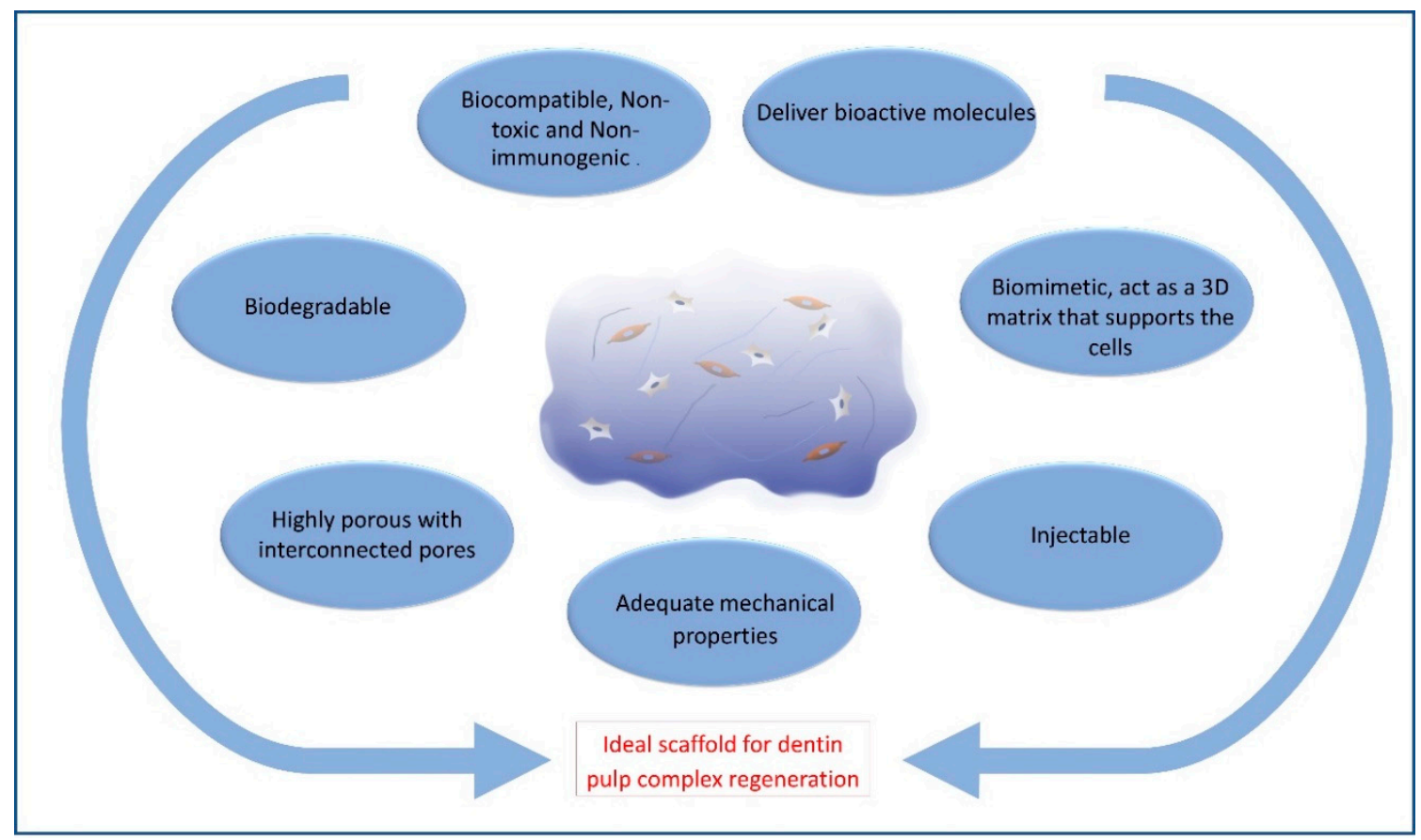

Figure 2. Schematic diagram showing criteria of ideal hydrogel scaffold.

On the biological level, hydrogel scaffolds used for dentin-pulp complex regeneration and their degradation by-products should be biocompatible, non-toxic, non-immunogenic, and should not induce significant inflammatory reactions. They also should allow the encapsulation or surface adhesion of cells, and promote cellular migration, proliferation, differentiation and function [37,39]. Ideally, the hydrogel should solidify at neutral $\mathrm{pH}$ and at physiological temperature to avoid cellular damage. Changes in temperature, $\mathrm{pH}$ or free radicals released during gelation can negatively affect loaded bioactive molecules or cell viability [40]. Natural hydrogels carry a lower risk for cytotoxicity [41]. Glutaraldehyde crosslinked gelatin hydrogels showed significantly lower biocompatibility as compared to 1-ethyl-3-(3-dimethyl aminopropyl) carbodiimide crosslinking in vitro and in vivo [41]. Synthetic hydrogels, on the other hand, carry a higher risk of cytotoxicity. It is noteworthy that hydrogels are injected before the gelation process, which imposes a higher risk for cytotoxicity. Therefore, all hydrogel components should be thoroughly examined for their cytotoxic effects. The small molecules used for the gelation process, such as unreacted monomer, initiator and crosslinkers, that can elicit cellular toxicity, should be carefully removed for safe clinical application [7,33]. Additionally, hydrogels derived from animal sources could be immunogenic [7].

The hydrogel scaffold should be degradable upon implantation to be replaced by newly formed tissues [42]. Ideally, the rate of scaffold degradation should be compatible with the rate of new tissue formation. Too-rapid scaffold degradation can compromise its cell-supporting function, while a too-slow degradation rate can hinder new tissue formation [26,43]. Hydrogels may undergo degradation via simple dissolution, hydrolysis, enzymatic degradation or a combination of the previous mechanisms. Simple dissolution is common with physically crosslinked hydrogels, whereby the hydrogel does not break into smaller molecules but rather dissolves in a solution with change in environmental conditions [7]. Hydrolysis, which is the most common mechanism for hydrogel degradation [44], occurs hereby via the breakdown of labile ester linkages in the polymer chain, while enzymatic 
degradation occurs via enzymatic cleavage of peptide bonds incorporated into the hydrogel polymeric chains $[45,46]$.

Scaffolds should have high porosity and interconnected pores, to allow vascularization, nutrients and waste diffusion, as well as cellular migration $[7,47]$. Increasing internal pores can compromise mechanical properties, while increasing gelatin pores can reduce material stiffness [48]. Adequate mechanical properties are essential for hydrogel scaffolds to provide support for the cells and withstand mechanical loading $[47,49]$. Hydrogel mechanical properties largely depend on hydrogel composition, concentration, method of fabrication in addition to crosslinking density, porosity and hydrogel modification [50-52]. Increasing the material mechanical properties can be achieved by increasing crosslinking density and decreasing its porosity, which can compromise degradability and cellular response $[7,47]$. Therefore, a balance should exist between hydrogel mechanical properties and degradability [33].

For dentin-pulp complex regeneration, injectable hydrogels combined with stem/progenitor cells is considered a promising approach in the tissue engineering field. This is primarily attributed to their ability to be injected inside the tooth and to adapt to the contour of the pulp chamber easily and successfully. Their gelation in situ occurs by the crosslinking of hydrogel precursors, making them able to fill all irregularities and all defects properly [53]. The material should be flowable at the time of injection and solidify once in place in response to changes in temperature, $\mathrm{pH}$, light, enzyme or the addition of a crosslinking agent [7]. Furthermore, the scaffold material should be biomimetic and act as a 3D matrix that supports the cells and mimics the ECM. It should also provide bioactive molecules, and promote cells attachment, proliferation, survival and differentiation to optimize tissue regeneration $[47,54,55]$. The hydrogels can further be biofunctionalized to enhance cellular response through incorporation of cell-binding sequences such as RGD into the hydrogel [56]. Further, hydrogels can be used for the local delivery of bioactive molecules, such as TGF- $\beta 1$, BMP-2, VEGF or PDGF, which might consequently support odontogenic differentiation [57]. These bioactive molecules can be released by diffusion, degradation, cleavage of the hydrogel or combination of the previous mechanisms [33]. Hydrogel drug release kinetics involve an initial burst release followed by a diffusion-dominated release phase, then a stage of combined diffusion and degradation, and finally the carried drug is released through polymer degradation [58].

\section{Mechanism of Action of Hydrogels in Dentin-Pulp Regeneration}

The hydrogels' mechanisms of action in vivo include their role as a space filling material, in addition to their roles as carriers for cells and bioactive molecules [59]. Hydrogels should maintain the desired volume and structural integrity for the required time to perform this function [59]. For dentin-pulp complex regeneration, hydrogels act as carriers of stem/progenitor cells with odontogenic potential, such as DPSCs [60-67], odontoblasts-like cells [68-70], HUVECs [64,71], SCAP [72,73], SHED [66,74-76], BMMSCs [66,77-80], PDLSCs [66], endothelial cells [78] and primary dental pulp cells [81]. They can also act as carriers for the local delivery of antibiotics, such as clindamycin [82] and bioactive molecules, aiming to promote tissue regeneration, such as VEGF [20,61,83], FGF [20,83-85], BMP [65], TGF- $\beta 1$ [20,86], stem cell factor [87], dentonin sequence [88] and RGD cell-binding motifs $[56,89]$. Once implanted in site, being biodegradable, hydrogels allow the release of bioactive molecules that influence the surrounding environment [90,91] (Figure 3). 


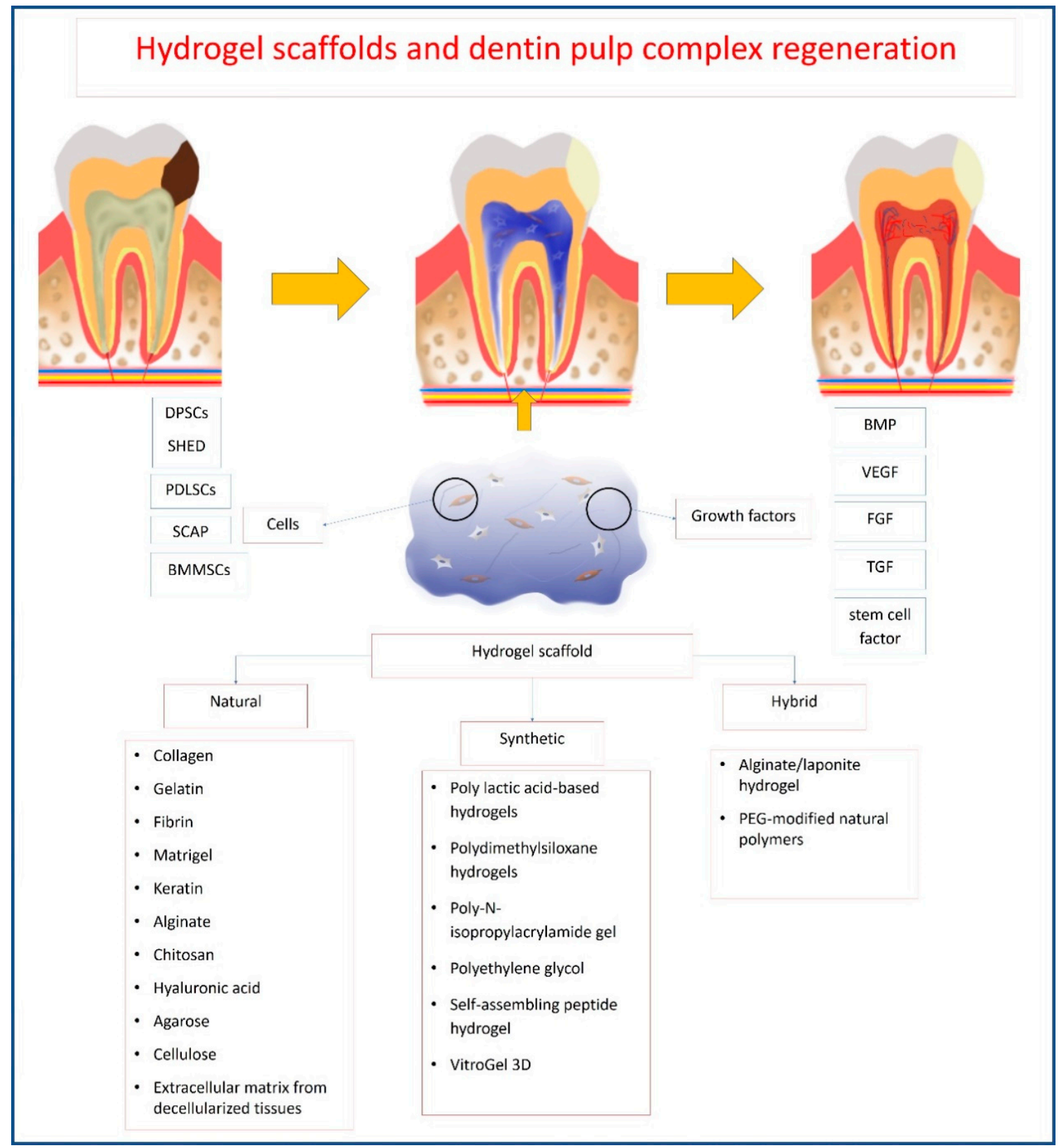

Figure 3. Schematic diagram showing mechanism of hydrogel action for dentin-pulp complex regeneration.

In this review, we aim to discuss the different hydrogels used in dentin-pulp complex regeneration, combined or not with stem/progenitor cells. As the polymer is the backbone forming any hydrogel, the classification of hydrogels in this review is based upon the nature of the main polymer/polymers forming the hydrogel.

\section{Hydrogels Used in Dentin-Pulp Complex Regeneration}

\subsection{Natural Hydrogels}

Naturally derived polymers are frequently used as injectable biomimetic hydrogel materials owing to their bioactivity and ability to interact with cells, as well as their biocompatibility and biodegradability with naturally occurring enzymes or through hydrolysis [92]. Natural polymers are either natural polypeptides of the ECM (e.g., collagen, fibrin, gelatin and keratin) or chemically 
similar to natural glycosaminoglycans (e.g., alginate, chitosan and hyaluronic acid). Most of the natural polymers are bioactive, containing cellular binding motifs, thus promoting cell adhesion, and/or present soluble signaling factors capable of regulating cell behavior. However, natural polymers suffer from certain limitations, including batch-to-batch variations, poor mechanical properties and uncontrolled degradation rate, compromising the materials' chemical and physical properties over time. Moreover, natural hydrogels may be inherently immunogenic or give rise to some immunogenicity due to the presence of contaminants, like proteins and endotoxins [93,94], in addition to the potential risk of transmitting pathogens from animal sources [92].

\subsubsection{Collagen}

Collagen is an insoluble fibrous protein of vertebrates that is the chief constituent of the fibrils of the connective tissue of skin, tendon and bone. The presence of collagen in all connective tissues makes it one of the most studied biomolecules of the ECM [95]. Collagen has a structural and chemical similarity to the predominant structural protein found in the ECM of several dental tissues. Collagen is highly biocompatible and bioactive, promoting cellular adhesion, cellular migration and cell proliferation. It is enzymatically biodegradable by collagenase. Although collagen has poor mechanical properties with high tensile strength, it is considered sufficient for pulpal tissue regeneration. The crosslinking of collagen can modify its mechanical and physical properties, however the added chemical agents could compromise cell survival and biocompatibility [96].

Crosslinking collagen hydrogel with cinnamaldehyde (CA), the most important constituent of cinnamon, significantly shortened the setting time, and increased compressive strength and surface roughness. CA per se did not increase alkaline phosphatase (ALP) activity, calcium nodule formation or the expression of odontogenic-related markers of human DPSCs cultured in a collagen hydrogel. The odontogenic markers investigated included DSPP, DMP-1, matrix extracellular phosphoglycoprotein (MEPE) and osteonectin (ON), while dental pulp cell proliferation and odontogenic differentiation cultured in collagen scaffolds were promoted in the presence of CA, as evident by the significantly higher expression of DSPP, DMP-1 and MEPE. Dental pulp cells spread across the CA crosslinked collagen, showing numerous cytoplasmic extensions, unlike cells in the uncrosslinked collagen matrix. This could be attributed to the enhanced physical properties of collagen by CA-induced crosslinking that upregulated the cellular adhesion, as compared to the sol state [60]. Variations in mechanical properties, such as stiffness, were shown to modulate human embryonic stem cells (ECs) differentiation. Substrate stiffness could act as a biomechanical regulatory factor through constraining the movement of tissues and cells. On stiffer matrices, cell movements becomes slower, cells exert higher tractions forces on their substrates and cell-generated forces are dissipated within the cell, possibly changing the protein conformation connecting the cytoskeleton and matrix $[97,98]$. This could explain the impact of increased compressive strength on human DPSCs count and odontogenic differentiation [60].

Thus, collagen matrices with tunable mechanical properties (e.g., stiffness) could affect cell-matrix interactions. Human amniotic membrane, which is composed of a single epithelial cell layer supported by a collagen-rich layer, is commonly used in ocular regeneration [99]. Crosslinked human amniotic membrane demonstrated higher rigidity and roughness, and positively influenced human limbal epithelial cells in vitro via the $\mathrm{Wnt} / \beta$ catenin pathway as compared to non-crosslinked amniotic membrane [100].

The stiffness and microstructure of collagen matrices could be tailored by modulating collagen concentration and the oligomer:monomer ratio [101]. Collagen hydrogels with varying stiffnesses were prepared by varying oligomer concentrations of $1.37 \mathrm{mg} / \mathrm{mL}$ (235 Pa) for endothelial differentiation, and $2.88 \mathrm{mg} / \mathrm{mL}$ ( $800 \mathrm{~Pa}$ ) for odontogenic differentiation. The effects of the incorporation of VEGF into 235 Pa oligomeric collagen, or BMP-2 into the 800 Pa oligomeric collagen, on DPSC's viability and differentiation were also investigated. DPSCs-laden oligomeric collagen gels with stiffnesses of 235 and $800 \mathrm{~Pa}$ demonstrated the slow release of simulated growth factors (GFs), supported long-term 
cell survival and favored the differentiation of cells to a specific lineage. The effect of stiffness on the cytoskeletal organization and cell shape was further evident, whereby stiffer collagen ( $800 \mathrm{~Pa}$ ) decreased the cell spreading and actin fiber organization, while softer collagen supported the growth of elongated DPSCs [61]. Real-time polymerase chain reaction (RT-PCR) data showed that the DPSCs cultured in $235 \mathrm{~Pa}$ matrices demonstrated an increased expression of endothelial markers, Von Willebrand Factor, platelet endothelial cell adhesion molecule-1 (PECAM-1) and vascular endothelial-cadherin after 28 days. The effect seemed to be enhanced upon VEGF incorporation. The 800 Pa DPSCs-laden oligomeric collagen matrices induced osteogenic differentiation, as was evident by an increase in ALP activity, and higher mineralization evident by Alizarin S staining demonstrated on day 21, an effect further amplified by BMP-2 incorporation [61].

Culturing DPSCs with their natural associated dental pulp ECM (pECM) was subsequently suggested to better mimic the cells' natural environment for enhanced cell culture and differentiation [81]. pECM is a loose highly hydrated viscous extracellular connective tissue matrix of collagenous and non-collagenous proteins, rich in hyaluronan, glycosaminoglycans and proteoglycans, all held together in a network of thin collagen fibrils, reticular fibrils and fibronectin. Col I and III are the two major structural components of the pECM [102]. The non-collagenous component contains a significant number of well-characterized bioactive regulatory molecules, such as DSP, DPP, BSP, DMP-1, OP, MEPE and members of SIBLINGs [103], in addition to other various non-phosphorylated proteins, various GFs and their receptors, and a variety of enzymes [102]. Cells grown on bovine pECM-coated cultureware did not demonstrate enhanced proliferation as compared to cells grown on uncoated control. On the contrary, the cells showed an abundant expression of stem/progenitor cells markers (including CD44, VIM and Sox2) and higher levels of pluripotent transcription factor Oct $\frac{3}{4}$, as compared to controls. Cells grown on uncoated control showed higher expression of the odontogenic cell fate markers (DSPP and DMP). The data suggested that cells cultured on pECM maintained undifferentiated stem/progenitor cell phenotype, compared to their controls [81].

To avoid the risk of ectopic mineralization, determining the fate of implanted cells in the pulp is an important consideration. Type I collagen hydrogel was employed to track the fate of rat pulp cells labeled with indium-111-oxine (111In-oxine), implanted in the empty pulp chamber space of a rat's upper first molar, by helical single-photon emission computed tomography (SPECT)/computed tomography (CT). One month following implantation, active fibroblasts, new blood vessels and nerve fibers were present in the cellularized 3D collagen hydrogel. SPECT provided a non-invasive follow-up of the implanted cells for up to 3 weeks, wherein signal intensity reflected implanted cell integrity. Reconstructed SPECT and CT scans revealed retention of the implanted cells in the pulp space with no evidence of systemic release [104].

\subsubsection{Gelatin Hydrogel}

Gelatin is a natural collagen derivative acquired through the hydrolysis of collagen triple helix into single molecules via alkaline or acid treatment processes [105]. Furthermore, gelatin is a biopolymer able to exhibit a thermoreversible sol-gel transition, whereby at higher temperatures it melts, and returns to a gel at lower temperature. This allows for fabricating cell/tissue encapsulation carriers using gelatin [106]. Gelatin is biocompatible, being natural, hydrophilic, biodegradable and non-immunogenic as compared to collagen $[107,108]$. The bloom value of gelatin (a method of measuring gel strength) can influence its properties. Gelatin with low bloom value has a low melting point, and a higher biocompatibility, which further endorse its use as a cell carrier for tissue regenerative purposes [106].

Gelatin retains RGD cell-binding motifs, which promote cellular attachment [109], as well as matrix metalloproteinase (MMP) binding domain, which allows its biodegradation [110]. Gelatin can also promote cellular proliferation and differentiation $[111,112]$ as well as DPSCs adhesion, proliferation, migration and odontogenic differentiation, as was evident by an increased mineralization, ALP activity and an increased expression of collagen I (Col I), OCN, DSPP and DMP-1 [108]. Gelatin is relatively 
inexpensive and readily available [113]. However, it has poor mechanical properties $[114,115]$ and is thermally unstable, as it is converted into a sol at temperatures above $37^{\circ} \mathrm{C}$ [116]. These shortcomings can be overcome by gelatin crosslinking, which involves adding chemical groups to gelatin active side chains, including $-\mathrm{OH},-\mathrm{COOH},-\mathrm{NH} 2$ and $-\mathrm{SH}$ groups [116].

In order to improve its biological properties, gelatin hydrogel was used for the local delivery of FGF $[84,85,117]$ and simvastatin for dental tissue regeneration [63]. Crosslinked gelatin hydrogel microspheres were impregnated with FGF-2 and mixed with pieces of gelatin sponge before implantation in rats' exposed dental pulp. Dentin particles were formed within the dentin defect and dental pulp cells showed an increased expression of DSPP [84]. Similarly, gelatin hydrogel microspheres incorporating different dosages of FGF-2 were associated with dentin regeneration. The quality of regenerated dentin was dependent on the concentration of FGF-2. FGF-2 moderated a dose-induced formation of dentin bridge upon implantation in rats' molars, and was associated with increased DMP-1 expression [117].

Furthermore, simvastatin-lactic acid-grafted gelatin micelles were fabricated through the incorporation of simvastatin into gelatin laden with lactic acid oligomer, which were further mixed with gelatin, followed by chemical crosslinking to form biodegradable gelatin hydrogels. Simvastatin-releasing hydrogel effectively increased ALP expression in DPSCs in vitro. It was also associated with increased calcification and DSP expression in vivo upon ectopic implantation in immunocompromised mice. The enhanced DPSCs' biological activity was attributed to increased levels of BMP-2 expression [63].

Gelatin hydrogels were enzymatically crosslinked with microbial transglutaminase to create a scaffold with variable stiffness. Crosslinked gelatin hydrogel substrates were associated with increased mineralization, odontogenic differentiation of DPSCs and increased expression of odontoblasts' markers, including OCN, DSPP and ALP, regardless of matrix stiffness or chemical stimulation using dexamethasone in vitro. The stiffness of the gelatin matrix was associated with the permanent differentiation of DPSCs even after being removed from the gelatin hydrogel surface [62].

Gelatin methacrylate (GelMA) is a gelatin-based hydrogel [118] derived through the reaction of gelatin with methacrylic anhydride, replacing amino groups present on the side chains of gelatin with methacryloyl groups. GelMA usually polymerizes under ultraviolet light, in the presence of a photo-initiator, into thermostable crosslinked hydrogel [116,119]. Being derived from gelatin, GelMA is biocompatible, and retains RGD cell-binding motifs and the MMP-binding domain, which support cell attachment and GelMA biodegradation, respectively [116]. GelMA can support cellular adhesion, proliferation, migration and organization, besides being relatively inexpensive [120]. GelMA is characterized by being thermally stable and can retain its physical properties at body temperature [121]. Additionally, GelMA is an ideal candidate for dentin-pulp complex regeneration as it can be easily injected into the exposed pulp cavity and photo-polymerized [64]. A GelMA hydrogel loaded with cells can be photopolymerized using dental curing light to facilitate its clinical translation for dental regeneration [122]. It has poor mechanical properties; however, it can be modified to increase its mechanical properties [118] through controlling the degree of methacrylation [120] or the polymer concentration [72].

Matrix stiffness and micropatterning of GelMA hydrogel scaffold can be altered to resemble odontoblasts' native environment, thus enhancing cellular response and behavior [68,72]. Increasing GelMA hydrogel stiffness through increasing the polymer concentration significantly increased SCAP proliferation [72] and odontoblasts-like cells' proliferation, viability and migration in vitro [68]. Additionally, micropatterning of the GelMA hydrogel via photolithograph promoted SCAP alignment and odontogenic differentiation [72]. Pre-vascularized hydrogel scaffolds with microchannels were fabricated through injecting GelMA hydrogel loaded with odontoblasts-like cells into the root fragment followed by photopolymerization. Odontoblasts-like cells encapsulated within GelMA hydrogel showed a tendency to spread close to dentinal walls, while endothelial colony-forming cells seeded in the microchannels formed endothelial monolayers and angiogenic sprouting in vitro [68]. 
In vivo findings also confirmed the suitability of cell-loaded GelMA hydrogel for dentin-pulp complex regeneration. Human DPSCs and human umbilical vein endothelial cells (HUVECs) suspended in GelMA hydrogel were injected into human root segments, sealed at one end using mineral trioxide aggregate. This was followed by the photo crosslinking of cells loaded with GelMA hydrogel. Root segments were then implanted subcutaneously in rats. Highly cellular and vascular pulp-like tissue was formed in the root segments. Further, GelMA remnants and cells became attached to the dentinal walls, and DPSCs developed cellular extensions into the dentinal tubules and secreted a matrix resembling reparative dentin [64].

Aiming to accelerate the formation of the intracanal blood clot required for dental pulp regeneration and to control pulpal bleeding, thrombin solution, a hemostatic solution, was added to the GelMA hydrogel before loading with DPSCs. An access cavity was prepared in the immature premolars of minipigs, the pulp was extirpated and the root canals were mechanically prepared. This was followed by over-instrumentation, followed by injection of the hydrogel loaded with cells into the canal, and tooth restoration. Cell-loaded GelMA was biocompatible as the DPSC's vitality was not affected, and an inflammatory response was not elicited in vitro. GelMA was also associated with successful apex maturation and the formation of vascular pulp-like tissue. Additionally, odontoblasts lining the pulp cavity and deposition of reparative dentin along dentinal walls were detectable. DPSCs-laden GelMA showed more promising results as compared to DPSCs-laden fibrin hydrogel, which was associated with periapical radiolucency and internal root resorption [67].

GelMA can be modified for the local delivery of growth factors. GelMAs conjugated with synthetic BMP-2 mimetic peptide and loaded with human DPSCs were prepared in bioink for the 3D bioprinting of stem cells-loaded dental constructs. DPSCs maintained viability, and displayed increased proliferation, mineralization and osteogenic differentiation, in addition to the expression of DSPP and OCN in vitro [65].

\subsubsection{Fibrin}

Fibrin is a naturally derived insoluble protein biopolymer, produced through the polymerization of fibrinogen protein (present in blood plasma) under the control of thrombin during blood clotting, which results in the formation of a fibrous polymer network important in hemostasis and wound healing [123]. Fibrin offers several advantages as compared to synthetic polymers and collagen in being of low cost, providing excellent biocompatibility and superior cell adhesion properties. It can be easily obtained from autologous sources, thus avoiding undesirable immunogenic reactions [96]. Fibrin is biodegradable in a controllable manner, has non-toxic degradation products and can be readily replaced by cell-derived ECM in a few days [124]. However, numerous obstacles hinder the wide use of fibrin gel in tissue engineering, including its weak mechanical properties, and the possibility of disease transmission and gel shrinkage [125]. The gel shrinkage can be decreased using fixing agents like poly L-lysine [96]. Mechanical properties of fibrin scaffolds can be easily tailored through adjusting the concentration and ionic strength of fibrinogen to obtain gel viscoelastic properties mimicking those of native ECM, promote the diffusion of nutrients and metabolites, as well as promote cell encapsulation [123]. In addition, the modification of the fibrin polymerization process could adjust the polymerized gel's mechanical properties through modifying the fiber thickness, degree of porosity and branching of the formed gel [126].

Fibrin and its degradation by-products lack any anti-bacterial activity, which could represent a drawback for the use of fibrin hydrogel in REP [123], since residual microorganisms in the canal space and dentinal tubules may hinder dentin-pulp complex regeneration [127]. The persistence of residual bacteria in the canal space after the disinfection step could be attributed to bacterial organization into biofilms on the dentin surface, making them innately more resistant to anti-microbial agents and deep penetration into the dentinal tubules. Residual bacteria affect dentin-pulp complex regeneration through triggering the host immune/inflammatory response [82]. The incorporation of anti-bacterial agents into the fibrin scaffold could represent a viable solution for such a limitation [123]. 
Other natural hydrogels, including chitosan-based ones, are known to possess anti-microbial activity against a variety of Gram-negative and Gram-positive bacteria, including Enterococcus faecalis (E. faecalis) [128,129], which are highly resistant to endodontic disinfectants and are frequently found in persistent intra-radicular or extra-radicular infections [130].

Thus, an injectable fibrin-chitosan hydrogel, composed of $10 \mathrm{mg} / \mathrm{mL}$ fibrinogen and $0.5 \%(w / w)$, $40 \%$ degree of acetylation chitosan, with physiological $\mathrm{pH}(\approx 7.2)$, was introduced. Enriching the fibrin-hydrogel with chitosan proved to be efficient in imparting anti-bacterial properties to the fibrin hydrogel, evident by the reduction in E. faecalis bacterial growth in contact with the hydrogel, as compared to the unmodified fibrin hydrogel [123]. Fibrin-chitosan cellularized hydrogels, encapsulating DPSCs, showed similar results to the unmodified fibrin hydrogel in terms of in vitro cellular viability and fibroblast-like morphology. Both hydrogel groups also exhibited similar DPSCs proliferation rates (detected by the expression of nuclear marker MKI67) and type I/III collagen production capacities, both detected by RT-qPCR and immunohistochemistry at the gene and protein level. Thus, the blending of chitosan in fibrin hydrogels would be a promising construct for REP, imparting an anti-bacterial effect without compromising the excellent biocompatibility of fibrin [123].

Still, a fibrin-chitosan hydrogel did not modify the early fibrin-triggered inflammatory response in the amputated dental pulp tissue in an in vivo model of rat incisor pulpotomy, as compared to the unmodified hydrogel. Both groups revealed a strong increase in interleukin-6 (IL-6) transcript in the dental pulp when compared to the dental pulp of untreated teeth. The leukocytes percentage was similar in all groups, as evaluated by fluorescence-activated cell sorting; however, the neutrophil granulocytes proportion in the leukocyte population increased in the dental pulp/hydrogel interface in both hydrogel groups. Using triple sequential immunofluorescence staining, M2 macrophages, but not M1, were clearly detected in the dental pulp close to this zone of neutrophil infiltration. This suggests that both hydrogels could promote the polarization of pro-regenerative M2 macrophages and that fibrin-chitosan hydrogel is a promising candidate for vital-pulp therapies [131].

Antibiotic-loaded nanoparticles (NPs) are also considered efficient for the eradication of bacterial biofilms, as they have the ability to deeply penetrate into biofilm matrices, thus improving the delivery of antibiotics to even the deepest and most persistent bacteria [132]. Fibrin hydrogel NPs incorporating free clindamycin (CLIN) or CLIN-loaded poly (D, L) lactic acid (PLA) demonstrated anti-bacterial effects against $E$. faecalis in a dose-dependent manner. Both groups also inhibited the formation of an E. faecalis biofilm. Thus, CLIN loading into PLA-NPs did not affect CLIN anti-microbial properties, and the NPs restrained CLIN release from the hydrogel as compared to when added in a free form [82]. NPs are known to ensure a high antibiotic concentration locally through protection of the drug structure, enhancing its bioavailability and biodistribution [133]. These results suggest that the CLIN-PLA-NPs allows the maintenance of the CLIN within the nanocomposite hydrogels in comparison to free CLIN (only tested for one day) [82]. DPSCs' viability and Col I synthesis in the cellularized hydrogel were similar to other hydrogel groups containing free CLIN, empty nanoparticles, or fibrin alone with no NPs. This suggests that the incorporation of CLIN-PLA-NPs did not affect the biocompatibility of the fibrin hydrogel [82].

The in vitro co-culturing of DPSCs and HUVECs in fibrin hydrogel loaded with DPSCs-derived extracellular vesicles (EVs) resulted in enhanced rapid neo-vascularization under starvation culture, without any exogenous GFs, to mimic the harsh environment of nutritional deficiency during pulp regeneration [134]. A higher frequency of apoptosis was also reported with co-cultures in EVs-loaded fibrin gel after five days. It was postulated that EVs stimulated the encapsulated cells to secrete VEGF in order to support rapid neo-vascularization $[71,134,135]$. Fibrin gels were thereby evidently able to retain and preserve the EVs' activity. DPSCs-derived EVs, labeled with Cell Mask Green dye, were internalized by cultured HUVECs, which ensured the delivery of the encapsulated GFs without exposure to the extracellular environment, thus protecting such vulnerable bioactive molecules [71]. 


\subsubsection{Matrigel}

Matrigel is a biologically active, sterile extract of basement membrane proteins derived from Engelbreth-Holm-Swarm mouse sarcoma. This type of tumor is characterized by having abundant ECM $[136,137]$. It is mainly composed of laminin, Col IV and entactin, in addition to a variable amount of basic FGF, epidermal growth factor, IGF-1, connective tissue growth factor and several transcription factors [138,139]. A growth factor-reduced version of Matrigel is also available [140]. Matrigel is commercially available as a frozen protein to be diluted in PBS, and can self-assemble into a hydrogel at $37^{\circ} \mathrm{C}$ [137]. Owing to its natural origin, Matrigel represents an excellent matrix for stem/progenitor cell culture that can mimic the ECM, promote cell interaction [138] and support the differentiation of many cell types [136]. Moreover, Matrigel can maintain SCAP viability [141]. Unfortunately, being driven from the tumor and due to batch-to-batch variabilities that may affect its mechanical and biochemical properties, there are important factors that hinder its use [138].

Investigations demonstrated that Matrigel exerts a positive effect upon culturing with dental stem cells. DPSCs transfected with the VEGF gene cultured on Matrigel promoted endothelial cell migration and vascular-tube formation [142]. Additionally, DPSCs cultured on Matrigel along with FGF-2 and TGF- 31 -releasing poly (glycolide-co-lactide) microspheres showed controlled growth factor release, which promoted stem/progenitor cells' proliferation and migration in vitro [143]. Rat bone marrow mesenchymal stem cells (BMMSCs) suspended in Matrigel hydrogel were loaded on porous poly (L-lactic acid) (PLLA) scaffold before implantation into pulpotomized rats' maxillary molars. Cellular pulp-like tissues were successfully regenerated with no signs of inflammatory response [77-80]. CD68+ newly recruited macrophages, with distinct phagosomes, were detectable around the scaffolds, and nestin-positive odontoblast were observed lining the pulpal surface of dentin near the implantation site, with strong DSPP expression confirming odontoblasts differentiation [77]. Dentin bridge formation was also detected [79]. This evident regeneration was attributed to BMMSCs, which survived and colonized within the implantation site and were able to differentiate into odontoblasts [80]. Loading Matrigel hydrogel with rat dermal microvascular endothelial cells, in addition to BMMSCs in the previous model, yielded a thicker dentin bridge, more organized pulpal tissue formation, and the upregulation of DSPP, nestin and pro-angiogenic factors' expression, including Bcl-2, Cxcl1, Cxcr2 and VEGF expression [78]. Furthermore, a shift in the macrophage population from phagocytic M1 phenotype to pro-reparative M2 phenotype was evident during pulp regeneration [79].

\subsubsection{Keratin Hydrogel}

Keratin is a natural structural fibrous protein associated with epithelial cells and skin appendages. It includes hard keratin occurring in hair, wool, hooves, claws and finger nails, in addition to soft keratin, which covers the epithelial surface $[144,145]$. Hard keratin is formed from tightly packed filaments in the cysteine-rich proteins matrix, while soft keratin is composed of loosely packed filaments [144,146]. Keratin is considered as one of the most abundant natural polymers [147]. It is usually extracted under low $\mathrm{pH}$ in the presence of reducing agents to give rise to keratein, or of oxidizing, agents giving rise to keratose $[145,148]$.

Extracted keratin proteins can self-assemble into highly porous fibrous scaffolds characterized by a reproducible architecture, which creates a 3D scaffold favorable for cellular attachment and growth $[145,149,150]$. It is also characterized by having RGD, Leu-Asp-Val (LDV) and Leu-Asp-Ser (LDS) cell-binding motifs which facilitate cellular attachment [151]. Keratin can affect biological cell behavior and properties [152,153], modulate cellular response to apoptotic signals [153], and influence epithelial cells' polarization. It is implicated in the regulation of innate immunity and epithelial inflammation [154]. Keratin can also regulate epithelial cell migration, proliferation, epithelial barrier formation and function, and wound healing, [152,155]. Furthermore, keratin hydrogel can promote the adhesion, proliferation and differentiation of adipose stem/progenitor cells into adipocytes, osteoblasts, vascular endothelial cells and myocyte in vitro, and enhance cutaneous wound healing in vivo [156]. 
Keratin-based hydrogels are biocompatible, highly porous, highly hydrophilic and characterized by a high swelling ratio, which can increase the hydrogel pore size and facilitate cellular and nutrient infiltration. Keratin hydrogels also exhibit slow biodegradation in vitro and in vivo, as a result of protein hydrolysis, which promotes tissue regeneration $[69,150]$. It also has adequate mechanical properties [157]. Additionally, keratin derived from human hair did not elicit an immune reaction [158].

Keratin hydrogels can be beneficial in dentin-pulp complex regeneration as they are associated with the upregulation of the proliferation and differentiation of odontoblasts and odontoblasts-like cells [69,70], as well as DPSCs in vitro [70], which was evidenced by the increased expressions of ALP and late odontoblast marker DMP-1 [69]. An injectable keratin hydrogel applied to rats' second molar with partial pulpotomy was compatible with pulp tissues. It was associated with the formation of dentin-like material, resembling reparative dentin, along the root canal walls with increased DMP-1 expression. However, the coronal portion of the pulp did not show signs of regeneration, and it was filled with hydrogel remnants along with pulp tissues and poorly calcified material [150]. Therefore, keratin hydrogel constitutes a natural, abundant, biocompatible and biodegradable natural hydrogel that can be used as an injectable stem/progenitor cells scaffold for dentin-pulp complex regeneration.

\subsubsection{Alginate}

Alginates are naturally derived anionic biopolymers extracted from brown seaweeds. They are unbranched polysaccharides consisting of covalently linked 1,4-linked $\beta$-D mannuronic acid (M) and $\alpha$-L-guluronic acid $(\mathrm{G})$ units, bonded together in different sequences and blocks along the polymer chain, depending on the origin of the alginate. Alginates can be prepared with a wide range of molecular weights (typically 50-100,000 kDa) [159]. Unmodified alginates are non-biodegradable in mammals, as mammals lack the enzyme (i.e., alginase) that can cleave the polymer chains. Alternatively, ionically crosslinked alginate hydrogels disintegrate progressively in vivo due to the release of the divalent cations that crosslink the hydrogel into the surrounding media in exchange with the monovalent cations, such as sodium ions [160]. In addition, the partial oxidation of alginate chains using sodium periodate makes it biodegradable through cleavage of the carbon-carbon bond of the cis-diol group in the uronate residue, and altering the chain conformation, promoting the hydrolysis of alginate in aqueous solutions [161]. Alginates also suffer from low mechanical stiffness and an uncontrolled degradation rate in vivo. Their mechanical strength can be improved through crosslinking using a calcium chloride bath, whereby calcium ions diffuse into the solution and crosslink the alginate [162]; increasing the calcium content and crosslinking density allows tailoring the mechanical properties [96]. Alginate hydrogels are transparent, allowing easy microscopic observation of entrapped cells and easy cell recovery without cellular damage. The use of highly purified and properly characterized alginates avoids the risk of batch-to-batch variation and immunogenic response [94,159]. A major limitation of alginate is its slow biodegradability and its being non-bioactive. These limitations could be overcome by a number of chemical and biochemical modifications [94].

Alginates are commonly used biomaterials for tissue repair, and when used as hydrogels, they can provide an ECM with hydration properties that promote cellular wound healing [86]. They are biocompatible, non-cytotoxic and non-immunogenic. They show good hydrogel-forming properties, whereby the gelation process is carried out using non-toxic solvents and under physiological conditions (in terms of $\mathrm{pH}$ and temperature), which provide easy cell encapsulation and entrapment, offering great potential for cell delivery. Alginate hydrogels are soft in nature, mimicking most native tissues [94]. Moreover, alginate has tunable mechanical properties that can be tailored to cover a range of stiffnesses to match various tissues. The tailoring of alginate mechanical properties can be done by varying different parameters, such as the polymer molecular weight, source, concentration and chemical modifications, and/or the type and degree of crosslinking [159].

Alginate hydrogels present a viable matrix for dental regeneration and can be used for the delivery of exogenous GFs or agents used to release endogenous GFs from tissues, thus enhancing the natural regenerative capacity of the dental pulp. The application of TGF- $\beta 1$ or HCL acid-treated 
alginate hydrogels to in vitro cultured human tooth slices resulted in reactionary dentinogenic responses, as evident by the increased predentin width [86]. TGF- $\beta 1$ has long been known as a modulator for the induction of dental pulp cells' proliferation and odontoblast-like cell differentiation, and the upregulation of ECM secretion by odontoblasts in the human dentin-pulp complex $[163,164]$. The increased matrix secretion observed with the acid-treated alginate hydrogel could be explained on the basis of a similar mechanism through the release of endogenous TGF- $\beta$ by the acid solubilization of the dentin matrix. The reparative dentinogenic response evident by the de novo matrix secretion on the cut pulpal surface suggests that TGF- $\beta 1$, from either the hydrogel containing it or endogenously from dentin, is a potent modulator of odontoblast-like cell differentiation from pulpal progenitor cells, besides inducing dentin matrix secretion [86].

The coupling of an entire protein to alginate in order to promote cellular adhesion is difficult to control, as it may trigger an unwanted immune response that causes proteolytic degradation. Hence the immobilization of cell recognition motifs, such as RGD peptide, is very common [165]. The RGD tripeptide motif represents the minimal essential cell adhesion peptide sequence associated with integrins in cell surface membranes. RGD is found in various ECM proteins, such as collagen, fibronectin, vitronectin, laminin and osteopontin $[94,165]$. Alginate hydrogels modified by RGD the peptide sequence promote cell adhesion, migration, proliferation and differentiation [96]. In addition, the interplay between stem/progenitor cells and vascular endothelium is a key process in early tissue morphogenesis. The generation of a functional vascular network that can reconnect with the native blood supply is crucial for securing proper blood supply for the modulation of neo-tissue formation by the stem/progenitor cells, to supply nutrients and oxygen as well as remove waste products [83]. By the in vitro co-culturing of HUVECs with DPSCs, it has been shown that HUVECs modulate the odonto/osteogenic differentiation of DPSCs. Moreover, DPSCs enhanced the angiogenic potential of HUVECs, as evident from the stabilization of the formed pre-existing vessel-like structures, and increased their longevity [166]. RGD-modified alginate hydrogels created a favorable environment for encapsulating DPSCs and HUVECs. These constructs could also retain and locally release the functional quantities of VEGF and FGF active molecules. The data showed that the combined addition of FGF and VEGF led to increased proliferation of both DPSC and HUVEC in the first $24 \mathrm{~h}$, compared to constructs containing a single morphogen or none at all. The RGD-modified alginate constructs showed a higher retention capacity for FGF-2, as compared to VEGF, with sustained release till day thirteen. On the other hand, the release of VEGF was almost complete within the first seven days. The authors suggested a modification of the constructs to include an exterior polysaccharide coating encapsulating DPSCs, and its optimization to promote the cells' differentiation into odontoblast-like cells. This coating could also slow down the release of the GFs, thus providing longer sustained release periods [83].

Three percent alginate hydrogel doped with pECM was employed for encapsulating primary DPSCs followed by induced differentiation in mineralizing medium, supplemented with dexamethasone, $\beta$-glycerophosphate and ascorbic acid. The data showed a time-dependent mineral deposition at the periphery of the hydrogel, as demonstrated histologically using hematoxylin and eosin, and by micro-CT analysis. Only cells adjacent to the outer surface of the alginate hydrogel with pECM contributed to the formation of mineralized tissue, which could be explained based on the reduced diffusion of mineralization signals into the hydrogel, differences in oxygen tension and/or physical restriction of the more deeply encapsulated cells [81].

Verma et al. [127] investigated the regenerative potential of oxidized alginate-fibrin hydrogel microbeads encapsulating DPSCs compared with traditional revascularization protocol. The results showed no significant differences between both experimental groups in terms of radiographic root development. The presence of residual bacteria was further defined to be detrimental for root development in both groups, as it was strongly associated with decreased root length, decreased apical and mid-root wall thickness and decreased dentin-associated mineralized tissue formation [127]. Conclusively, to promote pulp regeneration, the efficient disinfection of root canal space and dentinal 
walls is crucial before performing these procedures, with the required degree possibly higher than that required in traditional endodontic therapy [167].

Alginate hydrogel has also been used as a bioink for 3D bioprinting, and for the deposition and patterning of cell-laden 3D constructs $[168,169]$. Blending alginate hydrogels with dentin matrix components was utilized to construct bioink encapsulating SCAP. Soluble dentin molecules in the hydrogel bioink significantly enhanced the odontogenic differentiation of SCAP, as was evident by the increased ALP protein expression and upregulation of both ALP and runt-related transcription factor (RUNX2), which are osteo/odontogenic lineage-specifying markers [168].

As discussed earlier, alginate per se does not promote cellular adhesion as it lacks cell adhesion motifs $[94,160]$. To promote cell attachment to alginate hydrogels, blending them with gelatin was widely investigated for tissue engineering applications [160,169]. Hydrogel blends combining alginate with gelatin were also used as a bioink for constructing 3D printed scaffolds. The 3D bioprinting of glutaraldehyde crosslinked alginate and gelatin hydrogels produced a scaffold with enhanced physical and biological properties. This 3D bioprinting allowed for controlling the scaffold porosity interconnection and pore diameter to create a scaffold which mimics the cellular natural environment. The 3D printed alginate/gelatin hydrogel scaffold aqueous extracts enhanced human DPSCs cell proliferation, mineralization and osteogenic/odontoblastic differentiation in vitro, as evident by the increased expression of ALP, OCN and DSPP, as well as enhancing the deposition of bone-like mineralized nodules [169].

\subsubsection{Chitosan Hydrogel}

Chitosan consists of $\mathrm{N}$-acetyl glucosamine and glucosamine co-polymer units obtained from chitin [170]. Chitin is extracted from crustaceous shells, mollusks, insects, silkworm chrysalides and microorganisms [171]. Chitosan is provided in the form of gel, scaffold and fibers, and their properties depend on their molecular weight and the degree of acetylation. The extraction source and acetylation procedure regulate the polymer's final properties. Thereby, Chitosan is likely to be used as a biomaterial for dental application due to its anti-microbial, biocompatible properties, bioactivity, and ability to blend with other materials [172]. Notably, multiple studies presented that chitosan-based scaffolds displayed no cytotoxicity toward various cell types, and had good in vitro biocompatibility [173-176]. The nature of the crosslinking agent can impact chitosan cytocompatibility. Glutaraldehyde crosslinked chitosan was associated with higher cytotoxicity as compared to either non-crosslinked chitosan or genipin crosslinked chitosan [176].

Chitosan hydrogel networks are classified, based on the chitosan crosslinking methodology and preparation, into two categories. Chemically crosslinked hydrogels are irreversible formed by covalent bonding of the chitosan macromers, which can occur through crosslinkers or a photo-polymerization reaction, while physically crosslinked hydrogels develop through physical interactions, such as ionic interactions or secondary interactions [177]. The chemical modifications of chitosan do not change the fundamental skeleton of chitosan, but improve its properties. The possible chemical modifications examined were oligomerization, alkylation, acylation, quternization, hydroxyalkylation, carboxyalkylation, thiolation, sulfation, phosphorylation, enzymatic modifications and graft copolymerization, giving a wide range of derivatives with modified properties for specific use in pharmaceutical, biomedical and biotechnological fields [178].

Biodegradable glycol chitin-based thermo-responsive hydrogel scaffold (GC-TRS) is an injectable formulation, which is easily manipulated due to its unique thermo-responsive sol-gel transition property and inherent biocompatibility. GC-TRS allowed the proliferation and odontogenic differentiation of human DPSCs, as was evident by the expression of odontogenic/osteogenic markers, including DSPP, DMP1, ON and OP. Thus, it is considered as a promising material for pulp and dentin regeneration [179]. Thermo-sensitive hydrogels containing chitosan/ $\beta$-glycerophosphate displayed great biocompatibility, where cultured DPSCs showed adhesion and vitality. Furthermore, the chitosan/ $\beta$-glycerophosphate hydrogel maintained a sustained delivery of VEGF, which promoted the odontogenic differentiation of 
DPSCs more effectively than VEGF only, subsequently highlighting its potential application as a pulp capping material [180]. Another chitosan scaffold containing silver and bioactive glass promoted the in vitro odontogenic differentiation of DPSCs without affecting their proliferation, and downregulated the levels of inflammatory cytokines IL-1 $\beta$, IL-6, tumor necrosis factor-alpha and IL-8, with the concomitant inhibition of streptococcus mutans and lactobacillus casei growth [181].

An in vivo study investigated dentin-pulp tissue regeneration, using DPSCs loaded in a chitosan hydrogel scaffold combined with various GFs delivered into non-vital immature permanent teeth with induced apical periodontitis in dogs. Radiographic and histopathological evidence indicated significantly greater radicular thickening, root lengthening, apical closure of the root and the presence of a pulp-like tissue [182].

\subsubsection{Hyaluronic Acid Hydrogel}

Hyaluronic acid (HA) is a linear polysaccharide composed of alternating units of repeating disaccharide, D-glucuronic acid and N-acetyl-D-glucosamine, linked together via alternating $\beta-1,4$ and $\beta-1,3$ glycosidic bonds. It is a non-sulphated glycosaminoglycan found in the ECM of many soft connective tissues [183]. HA is biocompatible, biodegradable, bioactive, non-immunogenic and non-thrombogenic, and has high water affinity [184]. HA plays an important role in maintaining morphologic organization by preserving extracellular spaces and anti-oxidant effect, is a strong inflammation mediator [185] and activates various signaling pathways [186]. In light of the above, HA represents an outstanding candidate for tissue engineering $[187,188]$ and drug delivery systems [189].

In physiological environments, HA is subjected to multiple degradation processes, including hydrolysis and enzymatic digestion, via the hyaluronidase enzyme. Therefore, in order to control the degradation rate and improve its mechanical properties, crosslinking or conjugation strategies have been used to stabilize HA and at the same time to preserve their native biological functions [190].

Interestingly, the dental pulp contains large amounts of glycosaminoglycans [191]. HA was found to contribute to the initial development of the dentin matrix and dental pulp [192]. Injectable HA hydrogel, crosslinked with 1, 4-butanediol diglycidyl ether, has shown great potential as a scaffold for dentin-pulp complex regeneration. In vivo, this hydrogel was combined with BMP-4 and loaded with dental mesenchymal cells, then injected subcutaneously in nude mice. A typical dentin-like structure was observed having columnar odontoblast-like cells with polarized basal nuclei and blood vessels. These cells were aligned against the regenerated dentin-like tissue, while the dentinal tubules were arranged radially from the pulp-like tissue [193]. Another injectable HA hydrogel, based on hydrazone crosslinking between hydrazide and aldehyde groups, reinforced with cellulose nanocrystals and enriched with human PL, was examined for endodontic regenerative therapies. Since HA plays a crucial role in stimulating wound healing and tissue regeneration through increasing cellular proliferation and regulating angiogenesis, this hydrogel was suggested to be suitable as a supportive matrix for cell culture and promoting cell sprouting. This hydrogel also acted as a GF-controlled delivery system through its sustained release of chemotactic and pro-angiogenic GFs. Together with the fact that this hydrogel can be injected easily into any desired defect and crosslinked in situ, this clearly endorsed it for regenerative dentistry [194].

A photo crosslinkable hyaluronic acid/platelet lysate (HA/PL) hydrogel system was developed by modifying HA with methacrylic anhydride and curing by ultraviolet light exposure to create a further hydrogel for dentin-pulp repair. PL delivers multiple cytokines and GFs involved in wound healing, which could help HA hydrogels to increase pulp cell proliferation. HA/PL hydrogels successfully recruited cells from the cell monolayers of human DPSCs obtained from permanent teeth. Following odontogenic induction, human DPSCs seeded on HA/PL hydrogel showed the most abundant calcium deposits, with increased metabolic activity and proliferation of human DPSCs at all time points. These results provided clear evidence of the proposed system's potential as a promising repair system in dentin-pulp damages [195]. Furthermore, chemically conjugated methacrylate HA hydrogel was 
verified to be non-toxic to human DPSCs, as proven by methyl thiazolyl tetrazolium (MTT) assay, and was able to retain the stemness of human DPSCs with increased expression of NANOG and SOX2 though maintaining native stem cell shape [196]. Similarly, in a mini swine model, pulpectomized root canals were regenerated with vascularized pulp-like tissue, and accumulated with newly generated dentin-like tissue or osteodentin against the canal walls following transplantation with autologous and allogeneic swine DPSCs carried in a HA hydrogel [197].

Restylane, a Food and Drug Administration (FDA)-approved HA-based injectable hydrogel, is considered one of the most reported biopolymers for endodontic applications. Restylane was examined for its use as a scaffold for REP in vitro. This HA hydrogel promoted SCAP survival, mineralization, and odontoblastic differentiation. In comparison to Matrigel, which revealed significantly declined cell viability after $24 \mathrm{~h}$ as a result of Matrigel degradation, Restylane promoted greater ALP activity and upregulated the expressions of DSPP, DMP-1 and MEPE [198].

\subsubsection{Agarose Hydrogel}

Agarose is a linear component of the natural polysaccharide agar, together with agaropectin, which is obtained from sea algae. Structurally, Agarose is a polymer of agarobiose that consists of repeating units of D-galactose and 3, 6-anhydro-L-galactopyranose. Owing to its neutral, hydrophilic, porous, non-toxic, low-cost and biocompatible properties, it is used widely in biomedicine $[199,200]$. Agarose can be prepared as a thermal-reversible gel. Agarose's gelation and melting points change from $30-40{ }^{\circ} \mathrm{C}$ to $80-90^{\circ} \mathrm{C}$, respectively, depending on the molecular weight, the concentration and number of its side groups [201,202]. Agarose dissolves in water, forming a gel with a rigid net forming a 3D plastic and porous reticulum. Agarose gel appears as an apyrogenic, colorless, transparent gel, and is viscous-elastic at temperatures above $45^{\circ} \mathrm{C}$. Thus, specific treatment is needed for it to be extruded from the needle at $25^{\circ} \mathrm{C}$ (room temperature). Agarose is resorbed slowly by means of phagocytosis, as macrophages produce $\alpha$-galactosidase enzymes that cause polymer destruction [203-206].

The Agarose gelation process occurs in three consecutive steps: induction, gelation and pseudo-equilibrium. Hydrogen bonding and electrostatic interaction give rise to the helical structure of the Agarose molecule-forming gel $[207,208]$. Thereby, Agarose hydrogels are made without using toxic crosslinking agents [209,210], making it a biocompatible polymer [211]. Additionally, Agarose is used massively in biomedical applications owing to its controlled self-gelling properties, water-solubility, adjustable mechanical properties and non-immunogenic properties. Agarose has an adjustable water adsorption capacity, which provides the cells with a suitable microenvironment for cellular activity [208]. It has been used also to investigate mechanical load reactions for chondrocytes and mesenchymal stem cells [212], and in enamel regeneration [213].

Agarose hydrogel provided a microenvironment for dentin remineralization and enamel regeneration. Human-derived dentin slices were covered with ionic $\mathrm{CaCl}_{2}$ and non-ionic agarose hydrogel to occlude the exposed dentinal tubules and regenerate an enamel prism-like tissue on the dentin surface. Scanning electron microscopic (SEM) images demonstrated that crystals occluded the dentinal tubules. The densely packed growth mode along the long-axis enabled the crystals to align themselves in parallel to each other, to form an approximately $2.5 \mathrm{~mm}$ enamel prism-like layer on the dentin surface. Moreover, radiographic diffraction tests confirmed the hydroxyapatite nature of crystals. This could be an alternative therapeutic technique for the management of dentin hypersensitivity [214].

\subsubsection{Cellulose Hydrogel}

Cellulose is a fibrous, water-insoluble element found in plants, some animals (e.g., tunicates), fungi, and few bacteria. Cellulose hydrogels can be acquired through either the physical or chemical stabilization of cellulose solutions. Hydrogels can be obtained either directly from native cellulose or from cellulose derivatives, including methyl cellulose (MC), hydroxypropyl cellulose (HPC), hydroxypropylmethyl cellulose (HPMC) and carboxymethyl cellulose (CMC). In physical crosslinked 
gels, there is no covalent bonding formation or breakage, and the crosslinked network is formed through ionic bonding, hydrogen bonding, or an associative polymer-polymer interaction [215]. Physically crosslinked hydrogels are used as scaffolds for cell cultures, in cartilage models and as implants in bone defects [216], while chemical crosslinked hydrogels are prepared through crosslinking two or more kinds of polymer chains, either under ultraviolet irradiation [217] or with a functionalized crosslinker [218]. Cellulose-based composite hydrogels are made by mixing natural biodegradable polymers or synthetic polymers with cellulose to obtain composite hydrogels [219,220].

Since physically crosslinked hydrogels are reversible [221], they might flow under given conditions (e.g., mechanical loading), and might degrade in an uncontrollable manner. Owing to these shortcomings, physical hydrogels based on MC and HPMC are not recommended for use in vivo. On the contrary, MC hydrogels have been suggested as cell sheet harvest systems in vitro [222].

Chemical modifications for the cellulose backbone might be done before crosslinking to obtain stable hydrogels with given properties. Silated-HPMC has been developed, which crosslinks through condensation reactions upon decreasing the $\mathrm{pH}$ in water solutions [223,224]. Such hydrogels have the potential for both in vivo injection and in vitro culturing. They can be used as a scaffold in $3 \mathrm{D}$ cultures of osteogenic cells [225]. A Silated-HPMC hydrogel scaffold was able to extract and release non-collagenous matrix proteins from dentin powder, particularly TGF- $\beta 1$. Thus, a hydrogel containing endogenous growth factors and morphogens native to dentin is likely an important adjuvant in clinical REP [226].

The addition of hydroxyapatite nanoparticles to a CMC hydrogel stimulated the differentiation of DPSCs to the osteoblastic and odontoblastic lineage. This was supported by the upregulated expression of osteogenic markers ALP, RUNX2, COL-IA1 and OP, and odontogenic markers DMP-1 and DSPP, after 21 days of culture. Moreover, the DPSCs seeded on CMC-HA showed good biocompatibility, adhesion and viability. This indicates that DPSCs and CMC-HA hydrogel could be considered as promising candidates for dentin-pulp complex and periodontal tissue regeneration [227].

In an in vitro system, a recent thermo-responsive injectable formulation, which is composed of BAG (45S5 Bioglass ${ }^{\circledR}$ ) nanoparticles, Pluronic F127 and HPMC, has been investigated for potential dental application. This formulation was flowable, injectable at room temperature, dispersible at $4{ }^{\circ} \mathrm{C}$ and hardened at body temperature in 10 to $30 \mathrm{~min}$. The injectable bioactive glass was completely biocompatible, as assessed by MTT assay, with favored surface morphology, chemical structure and osteoinductive/osteoconductive properties that promoted osteoblast proliferation and growth significantly. The hydrophilicity and low surface energy of the HPMC and Pluronic F127 made the cells more liable to attach to the scaffold, and showed enhanced cell proliferation. Moreover, together they showed the ability to regenerate dentin in prepared cavities in extracted bovine teeth [228].

\subsubsection{Extracellular Matrix Hydrogels from Decellularized Tissues}

Decellularized scaffolds have become prevalent in the tissue engineering field. The first reported production of decellularized ECM from a tissue source to be used as a bioscaffold was the small intestinal submucosa in vascular applications [229-233]. The primary studies removed cells, while preserving the structural and functional proteins of the ECM, such as glycosaminoglycans, proteoglycans and GFs [234]. Thereby, the obtained materials retain the biochemical complexity, nanostructure and bioinductive properties of the native matrix [235]. ECM-derived materials are FDA-approved and have been used in millions of patients $[235,236]$.

ECM bioscaffolds can be transformed into injectable hydrogels in two main steps. ECM hydrogel can be formed by enzymatic digestion mainly by pepsin-mediated solubilization. Then, ECM is transported to physiological $\mathrm{pH}$ and salt conditions to match in vivo conditions, as well as to inactivate pepsin. The digested ECM self-assembles into a nano-fibrous hydrogel upon incubation at $37^{\circ} \mathrm{C}$ or injection in vivo $[237,238]$. The other approach is ECM homogenization using mortar and pestle, or high-speed shear mixing within a high salt buffer that physically disrupts the ECM particles and 
collagen fiber structure at physiologic $\mathrm{pH}$ [238-242]. SEM images of fully-formed ECM hydrogels reveal a loosely arranged nano-fibrous scaffold with interconnecting pores [243].

ECM hydrogel drawbacks include increased manufacturing time, and adding foreign protein for digestion. However, ECM hydrogels are widely used for various tissue engineering applications, owing to their ability to form an injectable hydrogel and their in vivo safety for any clinical application, thus providing a new minimally-invasive procedure for regenerative medicine [244].

A porcine urinary bladder matrix hydrogel containing bioactive glass with silver ions (Ag-BG/ECM) was investigated for dental pulp regeneration $[245,246]$. Ag-BG/ECM demonstrated enhanced anti-bacterial and regenerative properties. This fabricated hydrogel provided a better chemical composition and microenvironment that promoted DPSCs proliferation and differentiation potential, as well as the inhibition of apoptosis in vitro $[245,246]$, while via in vivo implantation into the dorsum of mice, Ag-BG/ECM induced pulp-dentin complex formation. The formed tissues presented a dentin-like morphology, with the collagen matrix deposited perpendicular to the odontoblast-like layer. These cells have the phenotypic characteristics of odontoblasts expressing nestin and DSP [245].

The human decellularized dental pulp matrix (DDPM-G) is fabricated by consecutive decellularization and sol-gel transition at $37^{\circ} \mathrm{C}$. In vitro, the human DDPM-G promoted human DPSCs attachment, cell migration and proliferation. Besides this, the human DDPM-G-coated surfaces aided the induced human DPSCs' differentiation into odontoblast-like and neural-like cells. Overall, the human DDPM-G holds tremendous translational potential in dental pulp regeneration, due to the ease of application, whereby the decellularized dental pulp contents are injected into the root canals and undergo gelation in situ. Therefore, it could serve as a carrier for exogenous stem cells due to its high compatibility [247]. Additionally, the injectable human-treated dentin matrix and alginate have demonstrated potential as pulp-capping agents clinically [248]. Studies discussing natural hydrogels used for dentin-pulp complex regeneration are summarized in Table 1. 
Table 1. Natural hydrogels.

\begin{tabular}{|c|c|c|c|c|c|c|c|}
\hline \multirow[b]{2}{*}{ Author } & \multicolumn{7}{|c|}{ Natural Hydrogels } \\
\hline & $\begin{array}{l}\text { Hydrogel } \\
\text { Used }\end{array}$ & Type of Study & Hydrogel Modification & Hydrogel Properties & Cells Used & $\begin{array}{c}\text { Upregulated Biological } \\
\text { Molecules }\end{array}$ & Outcomes \\
\hline & \multicolumn{7}{|c|}{ Collagen Hydrogel } \\
\hline $\begin{array}{l}\text { Souron et al., } \\
2014 \text { [104] }\end{array}$ & Collagen & In vivo & & $\begin{array}{l}\text { 3D collagen matrices, } \\
\text { mimic in vivo cell-cell and } \\
\text { cell-matrix interactions, } \\
\text { and regulate cell growth }\end{array}$ & $\begin{array}{l}\text { Rat pulp cells } \\
\text { labeled with } \\
\text { indium-111-oxine }\end{array}$ & & $\begin{array}{l}1 \text { month following implantation, active } \\
\text { fibroblasts, new blood vessels and } \\
\text { nervous fibers were present in the } \\
\text { cellularized 3D collagen hydrogel. }\end{array}$ \\
\hline $\begin{array}{l}\text { Kwon et al., } \\
2017 \text { [60] }\end{array}$ & Collagen & In vitro & $\begin{array}{l}\text { Crosslinked with } \\
\text { cinnamaldehyde (CA). }\end{array}$ & $\begin{array}{l}\text { Crosslinked collagen with } \\
\text { shorter gelation time } \\
\text { enhances cellular adhesion. } \\
\text { Higher stiffness enhances } \\
\text { odontogenic differentiation. }\end{array}$ & $\begin{array}{l}\text { Human dental } \\
\text { pulp stem cells } \\
\text { (DPSCs) }\end{array}$ & $\begin{array}{c}\text { Dentin } \\
\text { sialophosphoprotein } \\
\text { (DSPP), Dentin matrix } \\
\text { protein 1 (DMP-1), } \\
\text { Matrix extracellular } \\
\text { phosphoglycoprotein } \\
\text { (MEPE), Osteonectin (ON) }\end{array}$ & $\begin{array}{l}\text { CA shortened the setting time, } \\
\text { increased compressive strength and } \\
\text { surface roughness of collagen } \\
\text { hydrogels. CA-crosslinked hydrogels } \\
\text { promoted the proliferation and } \\
\text { odontogenic differentiation of human } \\
\text { DPSCs }\end{array}$ \\
\hline \multirow[t]{2}{*}{$\begin{array}{l}\text { Pankajakshan } \\
\text { et al., } 2020 \text { [61] }\end{array}$} & Collagen & In vitro & $\begin{array}{l}\text { Varying hydrogel stiffnesses } \\
\text { through varying oligomer } \\
\text { concentrations. } \\
\text { Incorporation of Vascular } \\
\text { endothelial growth factor } \\
\text { (VEGF) into } 235 \text { Pa collagen or } \\
\text { Bone morphogenetic protein } 2 \\
\text { (BMP-2) into the } 800 \text { Pa ones. }\end{array}$ & $\begin{array}{c}\text { Stiffness affect cytoskeletal } \\
\text { organization and cell shape } \\
\text { and specify stem cell } \\
\text { lineage. }\end{array}$ & DPSCs & $\begin{array}{l}\text { von Willebrand Factor } \\
\text { (vWF), } \\
\text { platelet endothelial cell } \\
\text { adhesion molecule } 1 \\
\text { (PECAM-1), } \\
\text { vascular } \\
\text { endothelial-cadherin }\end{array}$ & $\begin{array}{l}\text { Collagen hydrogels with tunable } \\
\text { stiffness supported cell survival, } \\
\text { and favored differentiation of cells to a } \\
\text { specific lineage. } \\
\text { DPSCs cultured in } 235 \text { Pa matrices } \\
\text { showed an increased expression of } \\
\text { endothelial markers, cells cultured in } \\
800 \text { Pa showed increased alkaline } \\
\text { phosphatase (ALP) activity and } \\
\text { Alizarin S staining. }\end{array}$ \\
\hline & \multicolumn{7}{|c|}{ Gelatin Hydrogel } \\
\hline $\begin{array}{l}\text { Kikuchi et al., } \\
2007 \text { [84] }\end{array}$ & $\begin{array}{c}\text { Gelatin } \\
\text { hydrogel }\end{array}$ & In vivo & $\begin{array}{l}\text { Crosslinked gelatin hydrogel } \\
\text { microspheres were } \\
\text { impregnated with fibroblast } \\
\text { growth factor 2 (FGF-2) and } \\
\text { mixed with collagen sponge } \\
\text { pieces. }\end{array}$ & $\begin{array}{l}\text { Gelatin hydrogel } \\
\text { microspheres (the water } \\
\text { content is } 95 \mathrm{vol} \% \text {; } \\
\text { diameters ranged } \\
\text { from } 5-15 \mu \mathrm{m} \text {; the average } \\
\text { of diameter was } 10 \mu \mathrm{m} \text { ) }\end{array}$ & & DSPP & $\begin{array}{l}\text { Controlled release of FGF2 from gelatin } \\
\text { hydrogels induced the formation of } \\
\text { dentin-like particles with dentin } \\
\text { defects above exposed pulp. }\end{array}$ \\
\hline $\begin{array}{l}\text { Ishimatsu et al., } \\
2009 \text { [117] }\end{array}$ & $\begin{array}{c}\text { Gelatin } \\
\text { hydrogel }\end{array}$ & In vivo & $\begin{array}{c}\text { Gelatin hydrogel } \\
\text { microspheres incorporating } \\
\text { FGF-2. }\end{array}$ & $\begin{array}{l}\text { Gelatin hydrogel } \\
\text { microspheres (the water } \\
\text { content is } 95 \mathrm{vol} \% \text {, } \\
\text { the average diameter was } 10 \\
\mu \mathrm{m} \text { ) }\end{array}$ & & DMP-1 & $\begin{array}{l}\text { Dentin regeneration on amputated } \\
\text { pulp can be regulated by adjusting the } \\
\text { dosage of FGF- } 2 \text { incorporated in } \\
\text { biodegradable gelatin hydrogels. }\end{array}$ \\
\hline
\end{tabular}


Table 1. Cont.

\begin{tabular}{|c|c|c|c|c|c|c|c|}
\hline \multirow[b]{2}{*}{ Author } & \multicolumn{7}{|c|}{ Natural Hydrogels } \\
\hline & $\begin{array}{l}\text { Hydrogel } \\
\text { Used }\end{array}$ & Type of Study & Hydrogel Modification & Hydrogel Properties & Cells Used & $\begin{array}{c}\text { Upregulated Biological } \\
\text { Molecules }\end{array}$ & Outcomes \\
\hline $\begin{array}{l}\text { Nageh et al., } \\
2013 \text { [85] }\end{array}$ & $\begin{array}{l}\text { Gelatin } \\
\text { hydrogel }\end{array}$ & Clinical trial & $\begin{array}{c}\text { FGF incorporated in gelatin } \\
\text { hydrogel. }\end{array}$ & $\begin{array}{l}\text { Acidic gelatin hydrogel } \\
\text { microspheres with a mean } \\
\text { diameter of } 59 \mu \mathrm{m} \text { and } \\
95.2 \% \text { water content. }\end{array}$ & & & $\begin{array}{l}\text { Follow-up X-ray revealed an increase } \\
\text { in root length and width with a } \\
\text { reduction in apical diameter } \\
\text { confirming the root's development. }\end{array}$ \\
\hline $\begin{array}{l}\text { Bhatnagar et al., } \\
\text { 2015 [62] }\end{array}$ & $\begin{array}{l}\text { Gelatin } \\
\text { hydrogel }\end{array}$ & In vitro & $\begin{array}{l}\text { enzymatically crosslinked } \\
\text { with microbial } \\
\text { transglutaminase (mTG). }\end{array}$ & $\begin{array}{c}\text { Hard and } \\
\text { soft gelatin-mTG gels } \\
\text { consist of } 1.125 \mathrm{~mL} \text { and } \\
1.488 \mathrm{~mL} \text { of a } 10 \% \text { gelatin } \\
\text { solution with } 0.375 \mathrm{~mL}(3: 1 \\
\text { (v/v) gelatin: } \\
\text { mTG), and } 0.012 \mathrm{~mL}(125: 1 \\
(v / v) \text { gelatin: } \mathrm{mTG}) \\
\text { of mTG } \\
\text { respectively }\end{array}$ & DPSCs & $\begin{array}{l}\text { Osteocalcin (OCN), ALP, } \\
\text { DSPP }\end{array}$ & $\begin{array}{l}\text { Enzymatically crosslinked gelatin } \\
\text { hydrogels are a potential effective } \\
\text { scaffold for dentin regeneration } \\
\text { regardless of matrix stiffness or } \\
\text { chemical stimulation using } \\
\text { dexamethasone. }\end{array}$ \\
\hline \multirow[t]{2}{*}{$\begin{array}{l}\text { Miyazawa et al., } \\
2015 \text { [63] }\end{array}$} & $\begin{array}{l}\text { Gelatin } \\
\text { hydrogel }\end{array}$ & $\begin{array}{l}\text { In vitro } \\
\text { In vivo }\end{array}$ & $\begin{array}{l}\text { Simvastatin-lactic acid } \\
\text { grafted gelatin micelles, } \\
\text { mixed with gelatin, followed } \\
\text { by chemical crosslinking to } \\
\text { form gelatin hydrogels. }\end{array}$ & $\begin{array}{c}\text { Carboxymethylcellulose } \\
\text { (CMC) value of micelles } \\
\text { was } 79 \mu \mathrm{g} / \mathrm{mL} . \\
\text { Water solubilization of } \\
\text { Simvastatin } 43 \text { wt.\%. } \\
\text { Simvastatin in the gelatin } \\
3.23 \text { wt. } \% \text {. The sizes of } \\
\text { granules } 500 \mu \text { m with rough } \\
\text { surfaces and uniformly } \\
\text { sized pores }\end{array}$ & DPSCs & $\begin{array}{l}\text { ALP, Dentin sialoprotein } \\
\text { (DSP), } \\
\text { BMP-2 }\end{array}$ & $\begin{array}{l}\text { It is possible to achieve odontoblastic } \\
\text { differentiation of DPSCs through the } \\
\text { controlled release of Simvastatin from } \\
\text { gelatin hydrogel. }\end{array}$ \\
\hline & \multicolumn{7}{|c|}{ Gelatin Methacrylate Hydrogel } \\
\hline $\begin{array}{l}\text { Athirasala et al., } \\
2017 \text { [68] }\end{array}$ & $\begin{array}{l}\text { Gelatin } \\
\text { Methacrylate } \\
\text { hydrogel } \\
\text { (GelMA) }\end{array}$ & In vitro & $\begin{array}{l}\text { Gelatin with methacrylic } \\
\text { anhydride. }\end{array}$ & $\begin{array}{l}\text { GelMA hydrogels of } 5,10 \\
\text { and } 15 \%(w / v) \\
\text { concentrations showed a } \\
\text { honeycomb-like structure. } \\
\text { Both } 10 \% \text { and } 15 \% \text { hydrogel } \\
\text { groups appeared to have } \\
\text { smaller pore sizes than } 5 \% \\
\text { GelMA. }\end{array}$ & $\begin{array}{l}\text { Odontoblasts like } \\
\text { cells (OD21) and } \\
\text { endothelial colony- } \\
\text { forming cells }\end{array}$ & & $\begin{array}{l}\text { Pre-vascularized hydrogel scaffolds } \\
\text { with microchannels fabricated using } \\
\text { GelMA is a simple and effective } \\
\text { strategy for dentin-pulp complex } \\
\text { regeneration. }\end{array}$ \\
\hline $\begin{array}{l}\text { Khayat et al., } \\
2017 \text { [64] }\end{array}$ & GelMA & In vivo & $\begin{array}{l}\text { Gelatin with methacrylic } \\
\text { anhydride. }\end{array}$ & & $\begin{array}{l}\text { DPSCs and human } \\
\text { umbilical vein } \\
\text { endothelial cells } \\
\text { (HUVECs) }\end{array}$ & & $\begin{array}{l}\text { GelMA hydrogel combined with } \\
\text { human DPSC/human umbilical vein } \\
\text { endothelial cells as promising pulpal } \\
\text { revascularization treatment to } \\
\text { regenerate human dental pulp tissues. }\end{array}$ \\
\hline
\end{tabular}


Table 1. Cont.

\begin{tabular}{|c|c|c|c|c|c|c|c|}
\hline \multirow[b]{2}{*}{ Author } & \multicolumn{7}{|c|}{ Natural Hydrogels } \\
\hline & $\begin{array}{l}\text { Hydrogel } \\
\text { Used }\end{array}$ & Type of Study & Hydrogel Modification & Hydrogel Properties & Cells Used & $\begin{array}{c}\text { Upregulated Biological } \\
\text { Molecules }\end{array}$ & Outcomes \\
\hline $\begin{array}{l}\text { Ha et al., } 2020 \\
{[72]}\end{array}$ & GelMA & In vitro & $\begin{array}{l}\text { Gelatin with methacrylic } \\
\text { anhydride hydrogels of } \\
\text { increasing concentrations. }\end{array}$ & $\begin{array}{l}\text { Increasing polymer } \\
\text { concentrations from } 5 \% \text { to } \\
10 \% \text { and } 15 \%(w / v), \\
\text { resulting in increasing } \\
\text { extents of crosslinking. } \\
\text { The elastic moduli of } \\
\text { hydrogels, increased with } \\
\text { increase in polymer } \\
\text { concentration from } 1.7 \mathrm{kPa} \\
\text { for } 5 \% \text { GelMA to } 7 \mathrm{kPa} \text { and } \\
16.4 \mathrm{kPa} \text { for } 10 \% \text { and } 15 \% \\
\text { GelMA hydrogels, } \\
\text { respectively. }\end{array}$ & $\begin{array}{l}\text { stem cells of the } \\
\text { apical papilla } \\
\text { (SCAP) }\end{array}$ & & $\begin{array}{c}\text { Substrate mechanics and geometry } \\
\text { have a statistically significant influence } \\
\text { on SCAP response. }\end{array}$ \\
\hline $\begin{array}{l}\text { Park et al., } \\
2020 \text { [65] }\end{array}$ & GelMA & In vitro & $\begin{array}{l}\text { GelMA conjugated with } \\
\text { synthetic BMP-2 mimetic } \\
\text { peptide prepared into bioink. }\end{array}$ & $\begin{array}{l}\text { GelMA exhibited a } \sim 2 \mathrm{kPa} \\
\text { storage modulus }\left(\mathrm{G}^{\prime}\right) \text { before } \\
\text { crosslinking and } \sim 4 \mathrm{kPa} \\
\text { after crosslinking. }\end{array}$ & DPSCs & DSPP, OCN & $\begin{array}{l}\text { BMP peptide-tethering bioink could } \\
\text { accelerate the differentiation of human } \\
\text { DPSCs in 3D bioprinted dental } \\
\text { constructs. }\end{array}$ \\
\hline \multirow[t]{2}{*}{$\begin{array}{c}\text { Jang et al., } 2020 \\
\text { [67] }\end{array}$} & GelMA & $\begin{array}{l}\text { In vitro } \\
\text { In vivo }\end{array}$ & $\begin{array}{l}\text { Thrombin solution added to } \\
\text { GelMA hydrogel. }\end{array}$ & & DPSCs & & $\begin{array}{l}\text { Gelatin hemostatic hydrogels may } \\
\text { serve as a viable regenerative scaffold } \\
\text { for pulp regeneration. }\end{array}$ \\
\hline & \multicolumn{7}{|c|}{ Fibrin Hydrogel } \\
\hline $\begin{array}{l}\text { Meza } 2019 \\
{[249]}\end{array}$ & $\begin{array}{l}\text { Platelet Rich } \\
\text { Fibrin } \\
\text { (PRF) }\end{array}$ & Case report & & & DPSCs & & $\begin{array}{l}\text { Autologous DPSCs isolated from } \\
\text { extirpated autologous inflamed dental } \\
\text { pulp were loaded on autologous PRF in } \\
\text { lower premolar tooth with irreversible } \\
\text { pulpitis for successful regeneration. }\end{array}$ \\
\hline $\begin{array}{l}\text { Ducret et al., } \\
2019 \text { [123] }\end{array}$ & Fibrin-chitosan & In vitro & $\begin{array}{l}\text { Enriching the fibrin-hydrogel } \\
\text { with chitosan. }\end{array}$ & $\begin{array}{l}10 \mathrm{mg} / \mathrm{mL} \text { fibrinogen and } \\
0.5 \%(w / w), 40 \% \mathrm{DA} \\
\text { chitosan, formed a hydrogel } \\
\text { at physiological } \mathrm{pH}(\approx 7.2), \\
\text { which was sufficiently fluid } \\
\text { to preserve its injectability } \\
\text { without affecting fibrin } \\
\text { biocompatibility }\end{array}$ & DPSCs & & $\begin{array}{l}\text { Chitosan imparted antibacterial } \\
\text { activity to fibrin hydrogel, reducing } E \text {. } \\
\text { faecalis growth. } \\
\text { The blending of chitosan in fibrin } \\
\text { hydrogels did not affect the viability, } \\
\text { proliferation and collagen-forming } \\
\text { capacity of encapsulated DPSCs as } \\
\text { compared to unmodified fibrin. }\end{array}$ \\
\hline $\begin{array}{l}\text { Mittal et al., } \\
2019 \text { [250] }\end{array}$ & PRF & Clinical trial & & & & & $\begin{array}{c}\text { PRF and collagen are better scaffolds } \\
\text { than placentrex and chitosan for } \\
\text { apexogenesis of immature necrotic } \\
\text { permanent teeth. }\end{array}$ \\
\hline
\end{tabular}


Table 1. Cont.

\begin{tabular}{|c|c|c|c|c|c|c|c|}
\hline & \multicolumn{7}{|c|}{ Natural Hydrogels } \\
\hline Author & $\begin{array}{l}\text { Hydrogel } \\
\text { Used }\end{array}$ & Type of Study & Hydrogel Modification & Hydrogel Properties & Cells Used & $\begin{array}{c}\text { Upregulated Biological } \\
\text { Molecules }\end{array}$ & Outcomes \\
\hline $\begin{array}{l}\text { Bekhouche et } \\
\text { al., } 2020 \text { [82] }\end{array}$ & Fibrin & In vitro & $\begin{array}{c}\text { Incorporation of clindamycin } \\
\text { loaded Poly (D, L) Lactic Acid } \\
\text { nanoparticles (CLIN-loaded } \\
\text { PLA NPs). }\end{array}$ & $\begin{array}{l}\text { Fibrin hydrogel constituted } \\
\text { a reservoir of CLIN-loaded } \\
\text { PLA NPs inhibiting } E \text {. } \\
\text { faecalis growth without } \\
\text { affecting cell viability and } \\
\text { function. }\end{array}$ & DPSCs & & $\begin{array}{l}\text { Fibrin hydrogels containing } \\
\text { CLIN-loaded PLA NPs showed an } \\
\text { antibacterial effect against E. faecalis } \\
\text { and inhibited biofilm formation. } \\
\text { DPSCs viability and type I collagen } \\
\text { synthesis in cellularized hydrogels } \\
\text { were similar to the unmodified } \\
\text { groups. }\end{array}$ \\
\hline $\begin{array}{l}\text { Renard et al., } \\
2020 \text { [131] }\end{array}$ & Fibrin-chitosan & In vivo & $\begin{array}{c}\text { Same formulation of } \\
\text { fibrin-chitosan hydrogel as } \\
\text { used by Ducret et al., } 2019 \\
{[123]}\end{array}$ & $\begin{array}{c}40 \% \text { DA chitosan } \\
\text { incorporation in the fibrin } \\
\text { hydrogel did not modify } \\
\text { modify dental pulpi } \\
\text { inflammatory/immune } \\
\text { response and triggered } \\
\text { polarization of } \\
\text { pro-regenerative M2 } \\
\text { macrophages. }\end{array}$ & & & $\begin{array}{l}\text { In in vivo model of rat incisor } \\
\text { pulpotomy, fibrin-chitosan } \\
\text { hydrogels imparted a similar } \\
\text { inflammatory response in the } \\
\text { amputated pulp as unmodified } \\
\text { fibrin. Both groups enhanced the } \\
\text { polarization of pro-regenerative M2 } \\
\text { macrophages. }\end{array}$ \\
\hline $\begin{array}{l}\text { Zhang et al., } \\
2020 \text { [71] }\end{array}$ & Fibrin & In vitro & $\begin{array}{c}\text { Fibrin hydrogel loaded with } \\
\text { DPSCs-derived extracellular } \\
\text { vesicles (EVs). }\end{array}$ & $\begin{array}{l}2 \mathrm{mg} / \mathrm{mL} \text { fibrinogen formed } \\
\text { a hydrogel which was able } \\
\text { to retain and preserve the } \\
\text { activity of EVs. Forming the } \\
\text { most extensive tubular } \\
\text { network forming at an EVs } \\
\text { concentration of } 200 \mu \mathrm{g} / \mathrm{mL}\end{array}$ & $\begin{array}{l}\text { Co-culture of } \\
\text { DPSCs and } \\
\text { HUVECs }\end{array}$ & VEGF & $\begin{array}{l}\text { Investigated hydrogels enhanced } \\
\text { rapid neovascularization under } \\
\text { starvation culture, increased } \\
\text { deposition of collagen I, III, and IV, } \\
\text { and promoted the release of VEGF. }\end{array}$ \\
\hline \multicolumn{8}{|c|}{ Matrigel 3D } \\
\hline $\begin{array}{l}\text { Mathieu et al., } \\
2013 \text { [143] }\end{array}$ & Matrigel & In vitro & & & DPSCs & & $\begin{array}{c}\text { Encapsulating transforming } \\
\text { growth factor beta1 } \\
\text { (TGF-b1) and FGF-2 in a } \\
\text { biodegradable Poly } \\
\text { glycolide-co-lactide (PGLA) } \\
\text { microsphere }\end{array}$ \\
\hline $\begin{array}{c}\text { Ito et al., } 2017 \\
{[77]}\end{array}$ & Matrigel & In vivo & & & $\begin{array}{l}\text { Bone marrow } \\
\text { mesenchymal stem } \\
\text { cells (BMMSCs) }\end{array}$ & Nestin, DSPP & $\begin{array}{l}\text { Pulp tissue regeneration was } \\
\text { successfully achieved. }\end{array}$ \\
\hline $\begin{array}{l}\text { Sueyama et al., } \\
2017 \text { [78] }\end{array}$ & Matrigel & In vivo & & & $\begin{array}{l}\text { BMMSCs and } \\
\text { endothelial cells } \\
\text { (ECs). }\end{array}$ & $\begin{array}{l}\text { DSPP, Nestin } \\
\text { Bcl-2, Cxcl1, } \\
\text { Cxcr2, VEGF }\end{array}$ & $\begin{array}{l}\text { The implantation of ECs with } \\
\text { mesenchymal stem cells accelerated } \\
\text { pulp tissue regeneration/healing } \\
\text { and dentin bridge formation. }\end{array}$ \\
\hline
\end{tabular}


Table 1. Cont.

\begin{tabular}{|c|c|c|c|c|c|c|c|}
\hline \multirow[b]{2}{*}{ Author } & \multicolumn{7}{|c|}{ Natural Hydrogels } \\
\hline & $\begin{array}{l}\text { Hydrogel } \\
\text { Used }\end{array}$ & Type of Study & Hydrogel Modification & Hydrogel Properties & Cells Used & $\begin{array}{c}\text { Upregulated Biological } \\
\text { Molecules }\end{array}$ & Outcomes \\
\hline $\begin{array}{c}\text { Gu et al., } 2018 \\
{[79]}\end{array}$ & Matrigel & In vivo & & & BMMSCs & & $\begin{array}{l}\text { M1-to-M2 transition of } \\
\text { macrophages plays an important } \\
\text { role in creating a favorable } \\
\text { microenvironment necessary for } \\
\text { pulp tissue regeneration. }\end{array}$ \\
\hline \multirow[t]{2}{*}{$\begin{array}{l}\text { Kaneko et al., } \\
2019 \text { [80] }\end{array}$} & Matrigel & In vivo & & & $\begin{array}{c}\text { BMMSCs } \\
\text { nucleofected with } \\
\text { pVectOZ-LacZ } \\
\text { plasmid encoding } \\
\beta \text {-galactosidase }\end{array}$ & DSPP & $\begin{array}{l}\text { BMMSCs could differentiate into } \\
\text { cells involved in mineralized tissue } \\
\text { formation in the functionally } \\
\text { relevant region. }\end{array}$ \\
\hline & \multicolumn{7}{|c|}{ Keratin Hydrogel } \\
\hline $\begin{array}{l}\text { Sharma et al., } \\
2016 \text { [69] }\end{array}$ & $\begin{array}{l}\text { Keratin } \\
\text { hydrogel }\end{array}$ & In vitro & & $\begin{array}{c}\text { Highly branched } \\
\text { interconnected porous } \\
\text { micro-architecture } \\
\text { with a maximum average } \\
\text { pore size of } 160 \mu \mathrm{m} \\
\text { and minimum pore size of } \\
25 \mu \mathrm{m} . \mathrm{G}^{\prime}>\mathrm{G}^{\prime \prime} \text { indicates } \\
\text { the elastic solid-like nature } \\
\text { of the gel. After } 3 \text { months } \\
\text { the degradation rate was } \\
68 \% \text {. }\end{array}$ & $\begin{array}{c}\text { odontoblast-like } \\
\text { cells } \\
\text { (MDPC-23) }\end{array}$ & ALP, DMP-1 & $\begin{array}{l}\text { Keratin enhanced proliferation and } \\
\text { odontoblastic differentiation of } \\
\text { odontoblast-like cells. Keratin } \\
\text { hydrogels may be a potential } \\
\text { scaffold for pulp-dentin } \\
\text { regeneration. }\end{array}$ \\
\hline $\begin{array}{l}\text { Sharma et al., } \\
2016 \text { [70] }\end{array}$ & $\begin{array}{l}\text { Keratin } \\
\text { hydrogel }\end{array}$ & $\begin{array}{l}\text { In vitro } \\
\text { In vivo }\end{array}$ & & $\begin{array}{c}\text { Highly branched } \\
\text { interconnected porous } \\
\text { micro-architecture } \\
\text { with a maximum average } \\
\text { pore size of } 160 \mu \mathrm{m} \\
\text { and minimum pore size of } \\
25 \mu \mathrm{m} . \mathrm{G}^{\prime}>\mathrm{G}^{\prime \prime} \text { indicates } \\
\text { the elastic solid-like nature } \\
\text { of the gel. After } 3 \text { months } \\
\text { the degradation rate was } \\
68 \% \text {. }\end{array}$ & $\begin{array}{l}\text { odontoblast-like } \\
\text { cells } \\
\text { (MDPC-23) and } \\
\text { DPSCs }\end{array}$ & & $\begin{array}{l}\text { Keratin hydrogel enhanced } \\
\text { odontogenic differentiation of } \\
\text { odontoblast-like cells and enhanced } \\
\text { reparative dentin formation. }\end{array}$ \\
\hline
\end{tabular}


Table 1. Cont.

\begin{tabular}{|c|c|c|c|c|c|c|c|}
\hline \multirow[b]{2}{*}{ Author } & \multicolumn{7}{|c|}{ Natural Hydrogels } \\
\hline & $\begin{array}{l}\text { Hydrogel } \\
\text { Used }\end{array}$ & Type of Study & Hydrogel Modification & Hydrogel Properties & Cells Used & $\begin{array}{c}\text { Upregulated Biological } \\
\text { Molecules }\end{array}$ & Outcomes \\
\hline $\begin{array}{l}\text { Sharma et al., } \\
2017 \text { [150] }\end{array}$ & $\begin{array}{l}\text { Keratin } \\
\text { hydrogel }\end{array}$ & In vivo & & $\begin{array}{c}\text { Branched interconnected } \\
\text { porous micro-architecture } \\
\text { with average pore size } 163.5 \\
\text { and porosity } 82.8 \% . \\
\text { There was a gradual } \\
\text { increase in } \mathrm{G}^{\prime} \text { from } 7 \% \text { to } \\
20 \%(w / v) \text { gel concentration. } \\
\text { The average contact angle } \\
\text { was } 35.5^{\circ} \text {. }\end{array}$ & & & $\begin{array}{l}\text { Keratins hydrogel can be a source } \\
\text { for biological treatment options for } \\
\text { dentin-pulp complex. }\end{array}$ \\
\hline & \multicolumn{7}{|c|}{ Alginate Hydrogel } \\
\hline $\begin{array}{l}\text { Dobie et al., } \\
2002[86]\end{array}$ & Alginate & In vitro & $\begin{array}{l}\text { TGF- } \beta 1 \text { or HCL } \\
\text { acid-treatment of the } \\
\text { hydrogels. }\end{array}$ & $\begin{array}{l}\text { Alginate hydrogels are } \\
\text { valuable for delivery of } \\
\text { growth factors (GFs) (or } \\
\text { agents to release } \\
\text { endogenous GFs) to } \\
\text { enhance reparative } \\
\text { processes of dentin-pulp } \\
\text { complex. }\end{array}$ & & & $\begin{array}{l}\text { Alginate hydrogel acted as an } \\
\text { efficient carrier for TGF- } \beta 1 \text {. } \\
\text { Furthermore, acid treatment of the } \\
\text { hydrogel aided in the release of } \\
\text { TGF- } \beta 1 \text { from dentin matrix. } \\
\text { Alginate-TGF- } \beta 1 \text { blends } \\
\text { stimulated reactionary } \\
\text { dentinogenic responses with } \\
\text { increased predentin width. }\end{array}$ \\
\hline $\begin{array}{l}\text { Smith et al., } \\
2015 \text { [81] }\end{array}$ & Alginate & In vitro & $\begin{array}{l}\text { Alginate hydrogel doped } \\
\text { with bovine dental pulp } \\
\text { extracellular matrix (pECM). }\end{array}$ & $\begin{array}{l}\text { 3D Alginate hydrogel } \\
\text { doped with pECM formed } \\
\text { 3D matrices. pECM } \\
\text { provides additional signals } \\
\text { for differentiation. }\end{array}$ & $\begin{array}{l}\text { Primary dental } \\
\text { pulp cells }\end{array}$ & & $\begin{array}{l}\text { Induced differentiation in the } \\
\text { mineralizing medium resulted in } \\
\text { time-dependent mineral deposition } \\
\text { at the periphery of the hydrogel. }\end{array}$ \\
\hline $\begin{array}{l}\text { Verma et al., } \\
2017 \text { [127] }\end{array}$ & Alginate-fibrin & In vivo & $\begin{array}{l}\text { Oxidized alginate-fibrin } \\
\text { hydrogel microbeads. }\end{array}$ & $\begin{array}{l}7.5 \% \text { oxidized alginate } \\
\text { coupled with fibrinogen } \\
\text { concentration of } 0.1 \% \\
\text { enhanced microbead } \\
\text { degradation, cell release, } \\
\text { and proliferation. }\end{array}$ & DPSCs & & $\begin{array}{l}\text { Oxidized alginate-fibrin hydrogel } \\
\text { microbeads encapsulating DPSCs } \\
\text { showed similar regenerative } \\
\text { potential to traditional } \\
\text { revascularization protocol in ferret } \\
\text { teeth. In both groups, the presence } \\
\text { of residual bacteria affected root } \\
\text { development. }\end{array}$ \\
\hline
\end{tabular}


Table 1. Cont.

\begin{tabular}{|c|c|c|c|c|c|c|c|}
\hline \multirow[b]{2}{*}{ Author } & \multicolumn{7}{|c|}{ Natural Hydrogels } \\
\hline & $\begin{array}{l}\text { Hydrogel } \\
\text { Used }\end{array}$ & Type of Study & Hydrogel Modification & Hydrogel Properties & Cells Used & $\begin{array}{c}\text { Upregulated Biological } \\
\text { Molecules }\end{array}$ & Outcomes \\
\hline $\begin{array}{l}\text { Athirasala et } \\
\text { al., } 2018 \text { [168] }\end{array}$ & Alginate & In vitro & $\begin{array}{l}\text { Blending alginate hydrogels } \\
\text { with soluble and insoluble } \\
\text { fractions of the dentin matrix } \\
\text { as a bioink for 3D printing. }\end{array}$ & $\begin{array}{l}\text { Dentin matrix proteins } \\
\text { preserve the natural } \\
\text { cell-adhesive (RGD) and } \\
\text { MMP-binding sites, } \\
\text { which are lacking in } \\
\text { unmodified alginate, } \\
\text { that are important for } \\
\text { viability, proliferation, } \\
\text { and differentiation. }\end{array}$ & SCAP & $\begin{array}{l}\text { ALP, Runt-related } \\
\text { transcription factor -2 } \\
\text { (RUNX2) }\end{array}$ & $\begin{array}{l}\text { Alginate and insoluble dentin } \\
\text { matrix (in 1:1 ratio) hydrogels } \\
\text { bioink significantly enhanced } \\
\text { odontogenic differentiation of } \\
\text { SCAP under the effect of the soluble } \\
\text { dentin molecules in the hydrogel. }\end{array}$ \\
\hline \multirow[t]{2}{*}{$\begin{array}{c}\text { Yu et al., } 2019 \\
\text { [169] }\end{array}$} & $\begin{array}{l}\text { Alginate and } \\
\text { gelatin } \\
\text { hydrogels }\end{array}$ & In vitro & $\begin{array}{l}\text { 3D bioprinted crosslinked } \\
\text { composite alginate and } \\
\text { gelatin hydrogels ( } 4 \% \text { and } \\
20 \% \text { by weight, respectively). }\end{array}$ & $\begin{array}{l}\text { 3D printing accurately } \\
\text { controls the interconnected } \\
\text { porosity and pore diameter } \\
\text { of the scaffold, and imitate } \\
\text { natural cell tissue in vivo. }\end{array}$ & DPSCs & ALP, OCN, DSPP & $\begin{array}{l}\text { 3D-printed alginate and gelatin } \\
\text { hydrogels aqueous extracts are } \\
\text { more suitable for the growth of } \\
\text { DPSCs, and can better promote cell } \\
\text { proliferation and differentiation. }\end{array}$ \\
\hline & \multicolumn{7}{|c|}{ Chitosan Hydrogel } \\
\hline $\begin{array}{l}\text { Park et al., } \\
2013 \text { [179] }\end{array}$ & $\begin{array}{l}\text { Chitosan } \\
\text { hydrogel }\end{array}$ & In vitro & $\begin{array}{l}\mathrm{N} \text {-acetylation of glycol } \\
\text { chitosan }\end{array}$ & $\begin{array}{c}\text { Glycol chitosan }(0.2 \mathrm{~g}) \text { and } \\
\text { acetic } \\
\text { anhydride }(0.87 \mathrm{~g}) \text { were } \\
\text { dissolved in } 50 \mathrm{~mL} \text { of a } \\
\text { mixture of distilled } \\
\text { water and methanol (50/50, } \\
v / v) \\
\text { degree of acetylation } 90 \% \\
\text { pore size ranged from } 5 \text { to } \\
40 \mathrm{~mm} \text {. }\end{array}$ & Human DPSCs & $\begin{array}{l}\text { DSPP, DMP-1, ON, } \\
\text { osteopontin }\end{array}$ & $\begin{array}{c}\text { Glycol chitin-based } \\
\text { thermo-responsive hydrogel } \\
\text { scaffold promoted the proliferation } \\
\text { and odontogenic differentiation of } \\
\text { human DPSCs. }\end{array}$ \\
\hline $\begin{array}{l}\text { El Ashiry et al., } \\
2018 \text { [182] }\end{array}$ & $\begin{array}{l}\text { Chitosan } \\
\text { hydrogel }\end{array}$ & In vivo & & $\begin{array}{c}\text { Chitosan } 1 \mathrm{~g} ; 77 \% \\
\text { deacylation, high molecular } \\
\text { weight, } \\
\text { was dissolved in } 2 \% \text { acetic } \\
\text { acid. }\end{array}$ & DPSCs & & $\begin{array}{l}\text { DPSCs and GFs incorporated in } \\
\text { chitosan hydrogel can regenerate } \\
\text { pulp-dentin-like tissue in non-vital } \\
\text { immature permanent } \\
\text { teeth with apical periodontitis in } \\
\text { dogs. }\end{array}$ \\
\hline $\begin{array}{l}\text { Wu et al., } 2019 \\
\text { [180] }\end{array}$ & $\begin{array}{l}\text { Chitosan } \\
\text { hydrogel }\end{array}$ & In vitro & $\begin{array}{l}\text { beta-sodium } \\
\text { glycerophosphate added to } \\
\text { chitosan (CS/ } \beta \text {-GP). }\end{array}$ & $\begin{array}{l}\text { viscosity: } 200-400 \mathrm{~m} \text { Pa·s } \\
2 \%(w / v) \text { chitosan solution } \\
56 \%(w / v) \text { beta-sodium } \\
\text { glycerophosphate } \\
\text { ( } \beta \text {-GP) solution } \\
\text { CS: } \beta \text {-GP is } 5 / \mathrm{L}\end{array}$ & DPSCs & $\begin{array}{l}\text { VEGF, ALP, } \\
\text { OCN, Osterix, } \\
\text { DSPP }\end{array}$ & $\begin{array}{c}\text { CS/ } \beta \text {-GP hydrogel could release } \\
\text { VEGF continually and promote } \\
\text { odontogenic differentiation of } \\
\text { DPSCs. }\end{array}$ \\
\hline
\end{tabular}


Table 1. Cont.

\begin{tabular}{|c|c|c|c|c|c|c|c|}
\hline \multirow[b]{2}{*}{ Author } & \multicolumn{7}{|c|}{ Natural Hydrogels } \\
\hline & $\begin{array}{l}\text { Hydrogel } \\
\text { Used }\end{array}$ & Type of Study & Hydrogel Modification & Hydrogel Properties & Cells Used & $\begin{array}{c}\text { Upregulated Biological } \\
\text { Molecules }\end{array}$ & Outcomes \\
\hline \multirow[t]{2}{*}{$\begin{array}{l}\text { Zhu et al., } 2019 \\
\quad[181]\end{array}$} & $\begin{array}{l}\text { Chitosan } \\
\text { hydrogel }\end{array}$ & In vitro & $\begin{array}{l}\text { Ag-doped bioactive glass } \\
\text { micro-size powder particles } \\
\text { added to chitosan } \\
\text { (Ag-BG/CS). }\end{array}$ & $\begin{array}{l}\mathrm{Ag}-\mathrm{BG} / \mathrm{CS} \text { pore diameter } \\
\text { reaching around } 60-120 \mu \mathrm{m} \text {. }\end{array}$ & DPSCs & $\begin{array}{l}\text { OCN, ALP, } \\
\text { RUNX-2 }\end{array}$ & $\begin{array}{l}\text { Ag-BG/CS enhanced the } \\
\text { odontogenic differentiation } \\
\text { potential of } \\
\text { lipopolysaccharide-induced } \\
\text { inflammatory-reacted dental pulp } \\
\text { cells and expressed antibacterial } \\
\text { and anti-inflammatory activity. }\end{array}$ \\
\hline & \multicolumn{7}{|c|}{ Hyaluronic Acid Hydrogel } \\
\hline $\begin{array}{l}\text { Chrepa et al., } \\
2016 \text { [198] }\end{array}$ & $\begin{array}{l}\text { Hyaluronic } \\
\text { acid (HA) } \\
\text { hydrogel }\end{array}$ & In vitro & & $\begin{array}{c}\text { SCAP/Restylane 1:10 } \\
\text { concentration } \\
\text { SCAP/Matrigel mixture at } \\
\text { 1:1 concentration } \\
\text { 1,4-butanediol diglycidyl } \\
\text { ether; DVS, divinyl } \\
\text { sulphone crosslinking agent }\end{array}$ & SCAP & $\begin{array}{l}\text { ALP, DSPP, DMP-1, } \\
\text { MEPE gene }\end{array}$ & $\begin{array}{l}\text { HA injectable hydrogel promoted } \\
\text { SCAP survival, mineralization and } \\
\text { differentiation into an } \\
\text { odontoblastic phenotype. }\end{array}$ \\
\hline $\begin{array}{l}\text { Yang et al., } \\
2016 \text { [193] }\end{array}$ & $\begin{array}{l}\text { Hyaluronic } \\
\text { acid hydrogel }\end{array}$ & In vivo & $\begin{array}{l}\text { HA crosslinked with } \\
\text { 1,4-butanediol } \\
\text { diglycidyl ether }\end{array}$ & $\begin{array}{c}\mathrm{HA}\left(1.5 \times 10^{6} \mathrm{Da}\right) \\
\text { 1,4-Butanediol diglycidyl } \\
\text { ether } \\
\text { crosslinking agent } \\
\text { HA concentration of } 20 \mathrm{mg} \\
\mathrm{mL}^{-1} \\
\text { gel particles of } 0- \\
400 \mathrm{~mm} .\end{array}$ & $\begin{array}{c}\text { Dental } \\
\text { mesenchymal cells }\end{array}$ & & $\begin{array}{l}\text { HA is an injectable scaffold that can } \\
\text { regenerate cartilage and } \\
\text { dentin-pulp complex. }\end{array}$ \\
\hline $\begin{array}{l}\text { Almeida et al., } \\
2018 \text { [195] }\end{array}$ & $\begin{array}{l}\text { Hyaluronic } \\
\text { acid hydrogel }\end{array}$ & In vitro & $\begin{array}{l}\text { Photo crosslinking of } \\
\text { methacrylated HA } \\
\text { incorporated with PL. }\end{array}$ & $\begin{array}{c}\text { High molecular weight } \\
\text { (1.5-1.8 MDa) HA } \\
1 \%(w / v) \text { HA solution (in } \\
\text { distilled water) reacted with } \\
\text { methacrylic anhydride (10 } \\
\text { times molar excess) } \\
\text { methacrylated } \\
\text { disaccharides } \% \text { was } 10.9 \pm \\
1.07 \% \\
\text { HA hydrogels } \\
\text { incorporating } 100 \%(v / v) \text { PL } \\
\text { Met-HA was } \\
\text { dissolved at a concentration } \\
\text { of } 1.5 \%(w / v) \text { in both of the } \\
\text { PBS and PL photoinitiator } \\
\text { solutions. }\end{array}$ & Human DPSCs & $\begin{array}{l}\text { ALP, collagen type I A } 1 \\
\text { strand (COLIA1) }\end{array}$ & $\begin{array}{l}\text { HA hydrogels incorporating PL } \\
\text { increased the cellular metabolism } \\
\text { and stimulate the mineralized } \\
\text { matrix deposition by hDPSCs. }\end{array}$ \\
\hline
\end{tabular}


Table 1. Cont.

\begin{tabular}{|c|c|c|c|c|c|c|c|}
\hline \multirow[b]{2}{*}{ Author } & \multicolumn{7}{|c|}{ Natural Hydrogels } \\
\hline & $\begin{array}{l}\text { Hydrogel } \\
\text { Used }\end{array}$ & Type of Study & Hydrogel Modification & Hydrogel Properties & Cells Used & $\begin{array}{c}\text { Upregulated Biological } \\
\text { Molecules }\end{array}$ & Outcomes \\
\hline $\begin{array}{l}\text { Silva et al., } \\
2018 \text { [194] }\end{array}$ & $\begin{array}{l}\text { Hyaluronic } \\
\text { acid hydrogel }\end{array}$ & $\begin{array}{l}\text { In vitro } \\
\text { Ex vivo }\end{array}$ & $\begin{array}{l}\text { HA hydrogels incorporating } \\
\text { cellulose nanocrystals and } \\
\text { enriched with Platelet lysate } \\
\text { (PL). }\end{array}$ & $\begin{array}{l}1 \text { wt. } \% \text { ADH-HA, } 1 \text { wt. } \% \\
\text { a-HA, } 0.125 \text { to } 0.5 \text { wt. } \% \\
\text { a-CNCs in } 50 \text { v/v\% PL } \\
\text { solution. }\end{array}$ & Human DPSCs & & $\begin{array}{l}\text { HA hydrogel enabled human DPSCs } \\
\text { survival and migration. }\end{array}$ \\
\hline $\begin{array}{c}\text { Zhu et al., } 2018 \\
\text { [197] }\end{array}$ & $\begin{array}{l}\text { Hyaluronic } \\
\text { acid hydrogel }\end{array}$ & In vivo & Crosslinked HA hydrogel & $\begin{array}{c}\text { Crosslinked HA gel } \\
(24 \mathrm{mg} / \mathrm{mL}) \text { mixed with } \\
\text { cells at 1:1-1:1.4 (v/v, i.e., } \\
\text { gel/cells) ratio with final cell } \\
\text { concentration of *2 } \cdot 107 / \mathrm{mL} \\
\text { 1,4-butanediol diglycidyl } \\
\text { ether; DVS, divinyl } \\
\text { sulphone crosslinking } \\
\text { agent } 9 \%\end{array}$ & DPSCs & $\begin{array}{c}\text { Nestin, DSPP, } \\
\text { DMP-1, Bone sialoprotein }\end{array}$ & $\begin{array}{l}\text { HA hydrogel regenerated pulp-like } \\
\text { tissue with a layer of dentin-like tissue } \\
\text { or osteodentin along the canal walls. }\end{array}$ \\
\hline \multirow[t]{2}{*}{$\begin{array}{l}\text { Niloy et al., } \\
2020 \text { [196] }\end{array}$} & $\begin{array}{l}\text { Hyaluronic } \\
\text { acid hydrogel }\end{array}$ & In vitro & $\begin{array}{l}\text { Converting sodium salt of HA } \\
\text { into Tetrabutylammonium } \\
\text { salt and subsequent } \\
\text { conjugation of Aminoethyl } \\
\text { methacrylate (AEMA) to HA } \\
\text { backbone. }\end{array}$ & $\begin{array}{c}\text { AEMA-HA macromers of } \\
\text { two different molecular } \\
\text { weights } \\
(18 \mathrm{kD} \text { and } 270 \mathrm{kD}) \\
1 \mathrm{~g} \text { of } \mathrm{H} / 100 \mathrm{~mL} \text { deionized } \\
\text { water, mixed with } 12.5 \mathrm{~g} \text { of } \\
\text { ion exchange resin was } \\
\text { converted from its } \\
\text { hydrogen form to its TBA } \\
\text { form } \\
\text { AEMA hydrochloride } \\
\text { (0.25 equivalent to HA } \\
\text { repeat units) }\end{array}$ & DPSCs & NANOG, SOX2 & $\begin{array}{c}\text { HA hydrogels have great potential to } \\
\text { mimic the in vivo 3D environment to } \\
\text { maintain the native morphological } \\
\text { property and stemness of DPSCs. }\end{array}$ \\
\hline & \multicolumn{7}{|c|}{ Agarose Hydrogel } \\
\hline \multirow[t]{2}{*}{$\begin{array}{l}\text { Cao et al., } 2016 \\
\text { [214] }\end{array}$} & $\begin{array}{l}\text { Agarose } \\
\text { hydrogel }\end{array}$ & In vitro & $\begin{array}{l}\text { Calcium chloride }\left(\mathrm{CaCl}_{2}\right) \\
\text { Agarose hydrogel }\end{array}$ & $\begin{array}{l}\text { 1.0 } \mathrm{g} \text { of Agarose powder, } \\
1.9 \mathrm{~g} \text { of } \mathrm{CaCl}_{2} \mathrm{H}_{2} \mathrm{O}\end{array}$ & & & $\begin{array}{l}\text { Agarose hydrogel promoted occlusion } \\
\text { of dentinal tubules and formation of } \\
\text { enamel prisms-like tissue on human } \\
\text { dentin surface. }\end{array}$ \\
\hline & \multicolumn{7}{|c|}{ Cellulose Hydrogel } \\
\hline $\begin{array}{l}\text { Teti et al., } 2015 \\
\text { [227] }\end{array}$ & $\begin{array}{l}\text { Cellulose } \\
\text { hydrogel }\end{array}$ & In vitro & $\begin{array}{l}\text { Hydroxyapatite was loaded } \\
\text { inside CMC hydrogel }\end{array}$ & $\begin{array}{c}\text { Degree of } \\
\text { carboxymethylation of } 95 \% \\
\text { (CMC) (average MW } 700 \\
\text { KDa) }\end{array}$ & DPSCs & $\begin{array}{l}\text { ALP, RUNX2, COL-IA1, } \\
\text { SPARC, } \\
\text { DMP-1, DSPP }\end{array}$ & $\begin{array}{l}\text { CMC-hydroxyapatite hydrogel up } \\
\text { regulated the osteogenic and } \\
\text { odontogenic markers expression and } \\
\text { promoted DPSCs adhesion and } \\
\text { viability. }\end{array}$ \\
\hline
\end{tabular}


Table 1. Cont.

\begin{tabular}{|c|c|c|c|c|c|c|c|}
\hline \multirow[b]{2}{*}{ Author } & \multicolumn{7}{|c|}{ Natural Hydrogels } \\
\hline & $\begin{array}{l}\text { Hydrogel } \\
\text { Used }\end{array}$ & Type of Study & Hydrogel Modification & Hydrogel Properties & Cells Used & $\begin{array}{c}\text { Upregulated Biological } \\
\text { Molecules }\end{array}$ & Outcomes \\
\hline $\begin{array}{l}\text { Aubeux et al., } \\
2016 \text { [226] }\end{array}$ & $\begin{array}{l}\text { Cellulose } \\
\text { hydrogel }\end{array}$ & In vitro & $\begin{array}{l}\text { Silanes grafted along the } \\
\text { hydroxy-propyl-methyl-cellulose } \\
\text { chains. }\end{array}$ & $\begin{array}{l}\text { nanoporous macromolecular } \\
\text { structure. Pores have an } \\
\text { average diameter of } 10 \mathrm{~nm}\end{array}$ & & TGF-b1 & $\begin{array}{l}\text { Cellulose hydrogel enhanced } \\
\text { non-collagenous matrix proteins } \\
\text { release from smashed dentin powder. }\end{array}$ \\
\hline \multirow[t]{2}{*}{$\begin{array}{l}\text { Iftikhar et al., } \\
2020[228]\end{array}$} & $\begin{array}{l}\text { Cellulose } \\
\text { hydrogel }\end{array}$ & In vitro & & $\begin{array}{l}\text { The surface area, average pore } \\
\text { size and particle size of BAG } \\
\left(45 S 5 \text { Bioglass }{ }^{\circledR}\right) \text { were } 65 \mathrm{~m} 2 / \mathrm{g} \\
5.7 \mathrm{~nm} \text {, and } 92 \mathrm{~nm} \text {, respectively. }\end{array}$ & $\begin{array}{l}\text { MC3T3-E1 cells } \\
\text { differentiated into } \\
\text { osteoblasts and } \\
\text { osteocytes. }\end{array}$ & & $\begin{array}{l}\text { The prepared injectable bioactive glass } \\
\text { hydroxypropylmethyl cellulose } \\
\text { (HPMC) and Pluronic F127 was } \\
\text { biocompatible in an in vitro system } \\
\text { and has the ability to regenerate dentin. }\end{array}$ \\
\hline & \multicolumn{7}{|c|}{ Extracellular Matrix Hydrogel } \\
\hline $\begin{array}{l}\text { Chatzistavrou } \\
\text { et al., 2014 } \\
\text { [246] }\end{array}$ & $\begin{array}{l}\text { Extracellular } \\
\text { matrix (ECM) } \\
\text { hydrogel }\end{array}$ & In vitro & $\begin{array}{c}\text { silver-doped bioactive glass } \\
\text { (Ag-BG) incorporated into } \\
\text { ECM }\end{array}$ & $\begin{array}{c}\text { Ag-BG powder form with } \\
\text { particle size }<35 \mu \mathrm{m} \text {. } \\
\text { ECM concentration of } 10 \\
\mathrm{mg} / \mathrm{mL} \\
\text { ECM60/Ag-BG40, } \\
\text { ECM50/Ag-BG50, } \\
\text { ECM30/Ag-BG70 } \\
\text { weight ratio. }\end{array}$ & DPSCs & & $\begin{array}{l}\text { Ag-BG/ECM presented enhanced } \\
\text { regenerative properties and } \\
\text { anti-bacterial action. }\end{array}$ \\
\hline $\begin{array}{l}\text { Wang et al., } \\
2015 \text { [245] }\end{array}$ & ECM hydrogel & $\begin{array}{l}\text { In vivo } \\
\text { In vitro }\end{array}$ & $\begin{array}{c}\text { silver-doped bioactive glass } \\
\text { (Ag-BG) incorporated into } \\
\text { ECM }\end{array}$ & $\begin{array}{c}\text { Ag-BG powder form with } \\
\text { particle size }<35 \mu \mathrm{m} . \\
\text { ECM pepsin digest stock } \\
\text { solutions of } 10 \mathrm{mg} \text { ECM } / \mathrm{mL} \\
\text { (dry weight) } \\
\text { Ag-BG: ECM }=1: 1 \text { in wt. } \% .\end{array}$ & DPSCs & & $\begin{array}{l}\text { Ag-BG/ECM showed antibacterial } \\
\text { property, induced dental pulp cells } \\
\text { proliferation and differentiation. } \\
\text { The in vivo results supported the } \\
\text { potential use of } \mathrm{Ag}-\mathrm{BG} / \mathrm{ECM} \text { as an } \\
\text { injectable material for the restoration of } \\
\text { lesions involving pulp injury. }\end{array}$ \\
\hline $\begin{array}{l}\text { Li et al., } 2020 \\
\text { [247] }\end{array}$ & ECM hydrogel & In vitro & & $\begin{array}{l}\text { Pre-gel solution was diluted } \\
\text { into } 0.75 \% w / v \text { and } 0.25 \% w / v \text {. }\end{array}$ & Human DPSCs & DSPP, DMP-1 & $\begin{array}{l}\text { decellularized matrix hydrogel derived } \\
\text { from human dental pulp effectively } \\
\text { contributed to promoting human } \\
\text { DPSCs proliferation, migration, } \\
\text { and induced } \\
\text { multi-directional differentiation. }\end{array}$ \\
\hline $\begin{array}{l}\text { Holiel et al., } \\
2020 \text { [248] }\end{array}$ & ECM hydrogel & Clinical trial & $\begin{array}{l}\text { Human treated dentin matrix } \\
\text { hydrogel was dispersed in } \\
\text { sodium alginate solution }\end{array}$ & $\begin{array}{c}\text { Particle sized } \\
\text { powder (range } 350-500 \mu \mathrm{m}) \\
5 \%(w / v) \text { of sodium alginate } \\
0.125 \mathrm{~g} \text { of sterile } \\
\text { human treated dentin matrix } \\
\text { was dispersed in the sodium } \\
\text { alginate solution with a } \\
\text { mass ratio of } 1: 1\end{array}$ & & & $\begin{array}{l}\text { Treated dentin matrix hydrogel } \\
\text { attained dentin regeneration and } \\
\text { conservation of pulp vitality. }\end{array}$ \\
\hline
\end{tabular}




\subsection{Synthetic Hydrogels}

Synthetic hydrogels are a group of materials with various biomedical applications. They are characterized by a high water absorption ability, improved tunable mechanical properties, thermostability and durability as compared to natural hydrogels, and are relatively inexpensive $[31,251,252]$. They feature different properties and characteristics that vary and can be tailored according to their chemical structure, crosslinking and method of fabrication [252,253]. Unfortunately, many synthetic scaffolds give rise to acidic byproducts upon degradation, which can elicit inflammation upon in vivo implantation [254]. Synthetic hydrogels can be divided into degradable hydrogels, such as PLA-based hydrogels, and non-degradable hydrogels, such as PEG.

\subsubsection{Poly Lactic Acid-Based Hydrogels}

Poly Lactic Acid (PLA) is a biocompatible, biodegradable, hydrophobic, biobased synthetic polymer obtained through the bacterial fermentation of renewable, plant-based carbohydrates. It has adequate mechanical properties, and its degradation byproducts are carbon dioxide and water, which are safe and nontoxic. PLLA is a commonly used isomeric form of PLA [255,256]. PLA-based scaffolds can upregulate DPSCs differentiation in addition to ALP, OCN, BSP, COL-I and DSPP expression in vitro, and enhance dentin formation in vivo [257]. PLA nanoparticles can be used as antibiotic carriers for reducing bacterial load for dental tissue regeneration [82]. PLA nanoparticles incorporating clindamycin loaded on fibrin hydrogel demonstrated a potent anti-bacterial effect without negatively affecting the DPSCs' vitality or function [82].

PLA can be conjugated with hydrophilic synthetic or natural polymers, such as PEG and polysaccharides, respectively, giving rise to hydrogels [252,255]. The PLA-PEG co-polymer is characterized by being soluble at room temperature and gel at body temperature, it is also biodegradable, biocompatible, constitutes an excellent carrier for drug delivery, and can enhance DPSCs adhesion and proliferation as well as the expression of odontoblasts-related markers ALP, DMP1, DSPP, COL-I and OPN in vitro $[252,258,259]$. Polylactic-polyglycolic acid (PLGA) and PEG co-polymer-based hydrogel were successfully used clinically for tooth apexogenesis and dentin regeneration [260].

\subsubsection{Polydimethylsiloxane Hydrogels}

Polydimethylsiloxane (PDMS) is one of the polymeric organosilicon compounds that are frequently ascribed to silicones [261]. Owing to its inert, nontoxic effect and stiffness versatility, PDMS is the most vastly used silicon-based organic polymer [262].

Taking into consideration that physical properties can affect the differentiation of stem/progenitor cells, the influence of the stiffness of PDMS on the behavior of DPSCs was investigated. Different ratios of liquid oligomeric base and curing agent (10:1, 20:1, 30:1 and 40:1) were utilized to form PDMS substrates with different stiffness properties (135 kPa, $54 \mathrm{kPa}, 16 \mathrm{kPa}$ and $6 \mathrm{kPa}$, respectively) [263]. PDMS was treated with dopamine solution in order to increase its cell adhesion potential. SEM results revealed that soft substrates changed the cell morphology and inhibited DPSCs' proliferation. Following conversion into osteogenic or odontogenic media, the expression level of osteogenic and odontogenic markers was positively correlated to the substrate stiffness, comprising ALP, OCN, OPN, RUNX-2, BMP-2, DSPP and DMP-1. The results of a Western blot analysis of the two important members of the Wnt signaling pathway, the glycogen synthase kinase- $3 \beta$ (GSK-3 $\beta)$ and $\beta$-catenin proteins, revealed that the mechanical properties promoted the function of DPSCs related to the Wnt $/ \beta$-catenin pathway, as $\beta$-catenin was significantly upregulated in DPSCs growing on stiffer substrates, which would affect the osteoblast, chondrocyte and odontogenic differentiation potential of DPSCs [264-266].

\subsubsection{Poly-N-Isopropylacrylamide Gel}

Pulp regeneration using the tissue engineering approach is challenging, since scaffolds increase the risk of inflammation and infection. To overcome that, an attempt to transplant scaffold-free 
3D cell constructs capable of forming pulp-like tissue derived from DPSCs was carried out. Rod-shaped 3D DPSCs constructs were fabricated by shaping sheet-like aggregates of DPSCs with a poly-N-isopropylacrylamide gel mold prepared through computed tomography image design [267]. Poly-N-isopropylacrylamide is a hydrogel with thermo-reversible gelation properties. It gels at temperatures ranging from 32 to $35{ }^{\circ} \mathrm{C}$, and reverts into a sol upon cooling $[268,269]$. To induce odontoblastic differentiation, DPSCs hydrogel constructs were cultured with odontoblastic differentiation media. In vitro results showed that DPSCs within the constructs remained viable even after prolonged culturing for 20 days. The regeneration ability of the construct was evaluated in a circumfluent space to mimic the therapeutic environment. An entire human tooth root was transplanted into the subcutaneous area of immunodeficient mice after being filled with the DPSCs constructs and sealed with the glass ionomer cement. Six weeks after implantation, pulp-like tissues rich in blood vessels were identified in the root canal, where the transplanted DPSCs differentiated into odontoblast-like cells at areas in proximity to dentin. This is attributed to the fact that dentin is a source of GFs (e.g., BMP-2 and TGF- $\beta$ ) $[9,270]$. Furthermore, immunofluorescent human CD31-positive endothelial cells were evident at the lumen of the regenerated tissue, which proves the anastomosis of the newly formed blood vessels with those of the host without requiring scaffolds or GF. The 3D constructs exhibited a self-organizing ability in vivo and in vitro. The self-organizing ability was evident in vitro through an expression of DSPP mRNA localized in the outer layer of cell constructs, while the expression of NANOG, a stem/progenitor cell marker, was significantly increased in DPSCs in the center of the constructs. The mineralization potential evaluated by ALP activity at the tenth day of culture indicated that DPSCs in the outer layer of the constructs differentiated into odontoblast-like cells, whereas DPSCs in the inner layer maintained their stemness properties [267].

\subsubsection{Polyethylene Glycol}

PEG is a synthetic polymer that is widely used to produce constructs for biological applications, owing to its unique properties, such as hydrophilicity, non-toxicity, low protein adhesion and non-immunogenicity [271-273]. In order to form a hydrogel, PEG must be crosslinked to attain a high water content construct. Additionally, the end hydroxyl groups of PEG molecules can be readily functionalized by groups, such as thiol, carboxyl and acrylate, or attached to other molecules or bioactive agents [43]. PEG-based hydrogels can be synthesized by the radiation crosslinking of PEG or via the covalent crosslinking of PEG macromers with the reactive chain ends [262].

PEG-maleate-citrate (PEGMC) was synthesized using PEG, (MW 200-1000 Da), maleic acid (MA) and citric acid. PEGMC hydrogel proved to be biodegradable, elastomeric, biocompatible and have light-curing crosslinking properties [274]. The efficacy of PEGMC hydrogel as an injectable light-cured drug delivery system for direct pulp capping has been investigated [275]. A pre-hydrogel solution was manufactured using PEGMC (45\% w/v), acrylic acid (AA) crosslinker ( $5 \%$ w/v), 2,2' -Azobis (2-methylpropionamidine) dihydrochloride (AAPH) photo-initiator $(0.1 \% w / v)$ and deionized water. Using a visible light-curing system, various volumes of the pre-hydrogel solution (50, 100, 150, and $200 \mu \mathrm{L}$ ) were used to measure the gelation time required for the photopolymerization of the solution to attain poly-PEGMC (PPEGMC) gel. A dose-dependent cytotoxicity experiment was used to evaluate the effects of varying concentrations of the polymerized hydrogel and its components on cell viability. The results revealed that the gelation time and the light-curing time for the hydrogel were comparable to composite resin. Light exposure for 30 and $60 \mathrm{~s}$ resulted in cell viability of $92.5 \%$ and $79.7 \%$, respectively, while upon exposure to $90 \mathrm{~s}$ of light, the cell viability significantly decreased to $48.9 \%$. For the hydrogel system, cell viability remained up to $80 \%$ after a period of $6 \mathrm{~h}$. Moreover, controlled $\mathrm{Ca}^{2+}$ release was attained from the calcium hydroxide-enclosed hydrogel, as quantified using a calcium reagent and spectrometer at $550 \mathrm{~nm}$. Simulating the clinical conditions, the injection ability and viscosity into plastic root canal blocks were confirmed for both mandibular and maxillary teeth in a dental model [275]. From these results, it could be deduced that the light-cured PEGMC 
hydrogel could represent a promising drug delivery vehicle for regenerative endodontics and vital pulp therapy.

\subsubsection{Synthetic Self-Assembling Peptide Hydrogel}

As discussed earlier, synthetic polymers provide highly tunable material properties, and are relatively inexpensive, biocompatible and biodegradable, however they fail to mimic the complex physiological functions of the native tissue. Collagen, as one of the most commonly used natural biomaterials, mimics natural ECM structurally, but it is expensive, difficult to process and suffers from immunogenicity and purity issues. Thus, novel synthetic or semisynthetic materials, including self-assembling peptide nanofibers, are under development in an attempt to overcome the deficiencies in these materials. They are considered promising candidates for future regenerative therapies, particularly REP, owing to their microstructure and the easier control of their synthesis routes. In addition, they form hydrogels with tunable viscoelastic properties, which are injectable, biocompatible, biodegradable, and can be modified by incorporation of bioactive molecules and motifs for enhanced biological performance [1]. Owing to their synthetic nature and controlled physicochemical properties, self-assembling peptides were described as a promising environment for pulp regeneration [276].

\section{Peptide Amphiphiles}

Peptide amphiphiles are synthetic self-assembling peptides designed and structured to incorporate both hydrophilic and hydrophobic residues. They can self-assemble in solution into nanofibers under specific conditions with numerous potential applications in regenerative medicine and drug delivery [277]. Peptide-based hydrogels are biocompatible, biodegradable, tunable and can be biofunctionalized to mimic the ECM $[278,279]$. Additionally, they do not require crosslinking, and therefore, cells and proteins can be added to the peptide without fearing their destruction due to exposure to chemical crosslinking. Unfortunately, they have low mechanical strength [7].

SHED and DPSCs were cultured in the self-assembling nanofiber peptide amphiphile, modified by incorporation of RGD and an enzyme-cleavable site. The hydrogel scaffold was biodegradable, biocompatible, easily handled, could be injected into small defects and it supported stem/progenitor cell proliferation, differentiation and mineralization in vitro [74].

The peptide hydrogel concentration can impact the hydrogel's physical as well as mechanical properties, and can influence cell behavior as well. Low concentrations of amphiphilic peptide hydrogels are more fluid than high-concentration hydrogels, which facilitate cellular connection. However, they are not steady, have poor mechanical properties and cannot establish a 3D environment for cellular growth. On the contrary, higher concentrations have low fluidity, which renders them difficult to be injected. The proper concentration was estimated at $0.25 \%$ hydrogel [280].

\section{RADA16-I Peptide Hydrogels}

RADA 16-I is a self-assembling synthetic peptide amphiphile composed of 16 amino acid residues. It consists of repeated segments of hydrophobic alanine and hydrophilic arginine, and aspartic acid amino groups [281]. RADA16-I self-assembling synthetic peptide amphiphile hydrogels, loaded with human DPSCs and umbilical cord mesenchymal stem/progenitor cells, were biocompatible, did not affect cell viability and supported cell proliferation particularly at lower $(0.25 \%)$ hydrogel concentrations. The hydrogel created a 3D environment which supported odontoblastic differentiation following BMP induction, and induced an increased expression of DSPP, DMP-1, ALP and OCN, in addition to increased mineralization. It was concluded that the co-culture of two cell types induced cellular interaction, which enhanced odontogenic differentiation in vitro [280].

Self-assembling RADA16-I peptide hydrogels can be modified by the addition of bioactive molecules to enhance dentin-pulp complex regeneration $[87,88]$. Self-assembling peptide hydrogel RADA16-I, incorporated with stem cell factor and loaded with DPSCs and HUVECs, 
was effective in promoting cell adhesion, proliferation, migration and angiogenesis in vitro [87]. Injectable self-assembled peptide hydrogel modified through the incorporation of dentonin sequence, a bioactive component of ECM phospho-glycoprotein, was biocompatible and supported DPSCs proliferation and mineralization in vitro [88].

Puramatrix $^{\mathrm{TM}}$ is a commercial RADA16-I self-assembling peptide formulated as an injectable aqueous solution that instantly polymerizes, forming a biodegradable scaffold of nanofibers, when exposed to physiologic concentrations of salts. Puramatrix ${ }^{\mathrm{TM}}$ has been tested in inducing the differentiation of primary cells and stem cells $[282,283]$. Puramatrix ${ }^{\mathrm{TM}}$ has yielded promising results for cardiac [284-287], neural [283,288], hepatic [289], bone [290] and murine calvaria [290] regeneration. The potentiality of Puramatrix ${ }^{\mathrm{TM}}$ as an injectable scaffold that is compatible with DPSCs growth and odontoblastic differentiation was investigated. DPSCs were grown in $0.05-0.25 \%$ Puramatrix ${ }^{\mathrm{TM}}$, and the cell viability and morphology were assessed using the WST-1 assay colorimetrically and by confocal microscopy. Verifying DPSCs' differentiation into odontoblast-like cells was investigated by measuring the expression of DSPP and DMP-1 upon loading human tooth slices with Puramatrix ${ }^{\mathrm{TM}}$ [291]. An elevated expression of these markers by DPSCs is correlated with the deposition of new dentin [292]. DPSCs exhibited the proliferative and morphological features of healthy cells in all concentrations of Puramatrix ${ }^{\mathrm{TM}}$. No difference was observed in the DPSCs' proliferation rate in relation to the concentration of Puramatrix ${ }^{\mathrm{TM}}$. Notably, following 21 days of culturing in dentin slices containing Puramatrix $^{\mathrm{TM}}$, DPSCs expressed DMP-1 and DSPP [291]. Therefore, it could be concluded that the dentin may have provided odontoblastic differentiation signaling molecules to the stem cells suspended within Puramatrix ${ }^{\mathrm{TM}}$ hydrogel.

Securing early angiogenesis through the application of VEGF [292] or co-culturing with vascular endothelial cells [293] could guarantee a successful outcome in dental pulp regeneration [294]. However, VEGF is an essential coordinator for the remodeling of ECM and angiogenesis, but the resulting blood vessels have the tendency for leakage due to structural incompatibilities [295,296]. In relation to this, stromal-derived factor- 1 alpha $(\mathrm{SDF}-1 \alpha)$ is a strong stimulator of the maturation of blood vessels [297,298], and it recruits pericytes and smooth muscle cells to mature and stabilize the newly formed blood vessels [299]. Therefore, human DPSCs, transfected for the overexpression of VEGF-red fluorescent protein (VEGF-RFP), SDF-1 $\alpha$ - green fluorescent protein (SDF- $1 \alpha-G F P)$, or both genes, using lentivirus were evaluated for their pulp regeneration potential in vivo and in vitro [142]. The transfected cells revealed an upregulated proliferation rate assessed by cell counting kit 8 (CCK-8) and MTT assays at different culturing times. Furthermore, transfected DPSCs promoted the in vitro migration of endothelial cell and vascular-tube formation in Matrigel. When injecting the modified DPSCs enclosed in Puramatrix ${ }^{\mathrm{TM}}$ hydrogel into the root canals of $6 \mathrm{~mm}$ tooth pieces and implanting them into immunodeficient mice for four weeks, the DPSCs/SDF-1 $\alpha+$ DPSCs/VEGF-mixed group resulted in a significant increase in the length of formed pulp-like tissue, as well as vessel area density, as compared to the DPSCs/VEGF group, which indicated a synergistic effect of these two cells when cultured together. Neo-angiogenesis induced by VEGF and SDF-1 $\alpha$ overexpressing DPSCs seemed to be less dependent on sprouting (angiogenesis), but occurred via an increase in the cross-sectional area of blood vessels, as most of the vascular lumens within the regenerated pulp-like tissue were perfused, as clearly shown by Haemotoxylin and Eosin staining. Immunohistochemical staining by human CD31 showed only focal single cell positives, rather than circular positives, around the lumens [142]. This was attributed to the formation of the vessel lumen by a combination of host endothelial cells and DPSCs-differentiated endothelial cells [276,300]. Accordingly, an enhanced area of vascularized pulp could be attained in vivo using combined VEGF and SDF- $1 \alpha$ overexpression in DPSCs. RGD was modified by incorporating the two functional peptides PRG and KLT (RGD-mimicking peptide and VEGF mimetic peptide sequence, respectively), which further provided a 3D environment favorable for DPSCs and HUVECs adhesion and proliferation, besides angiogenic and odontogenic differentiation in vitro, and stimulated dentin-pulp complex regeneration in vivo following implantation in rats' pulpotomized molars [89]. 
Prevascularization of the cell/scaffold construct by endothelial cells is another attempt to develop a novel strategy to trigger angiogenesis in the engineered pulp tissues through rapid anastomosis between the bioengineered cellular/tissue construct and the host vasculature [301,302]. Nevertheless, endothelial cells are sensitive and usually undergo apoptosis in the absence of angiogenesis-related factors, following their incorporation into scaffold materials [303]. Therefore, a 3D culture system that mimics the natural cell milieu, by providing cell-cell interactions-related signaling molecules independent of the used scaffold, may clarify the role of HUVECs interactions during angiogenesis [276]. Commercially available HUVECs, DPSCs extracted from human sound third molars, or co-cultures of different ratios (3:1, 1:1, or 1:3) of both cell types were encapsulated in 3D Puramatrix ${ }^{\mathrm{TM}}$ using the Transwell culture model, whereby HUVECs incorporated in Puramatrix ${ }^{\mathrm{TM}}$ were layered on a monolayer of DPSCs. Despite the lack of exogenous angiogenesis-related factors, the peptide nanofiber enhanced in vitro cell survival, migration and capillary formation, monitored by confocal microscopy for two weeks. It was postulated that DPSCs promoted early vasculature formation by enhancing the expression of VEGF and the migration of HUVECs. DPSCs/HUVEC co-enclosed Puramatrix ${ }^{\mathrm{TM}}$ exhibited vascularized pulp-like tissue with spots of osteodentin after being injected into the root canals of root segments and transplanted into mice for four weeks. The protein level of ALP and von Kossa staining for mineralization revealed that the co-cultured groups (Puramatrix ${ }^{\mathrm{TM}}+3: 1$ DPSCs:HUVECs, and Puramatrix ${ }^{\mathrm{TM}}+1: 1$ DPSCs:HUVECs) exhibited more mineralization than the DPSCs monocultures in vivo. Moreover, immunohistochemical analysis for human-specific CD31, nestin and DSP revealed that the co-cultured groups demonstrated more ECM and vascularization as compared to other groups [276]. Thus, it could be concluded that despite DPSCs being key players in initial angiogenesis, co-ordination between HUVECs and DPSCs is needed to accomplish a balance between angiogenesis, ECM deposition and mineralization on the nanofibrous peptide scaffold, in order to attain the efficient promotion of the cell-cell interactions and cellular cross-talk required for tissue regeneration.

The ability of SHED to construct a functional dental pulp when injected into root canals suspended in Puramatrix ${ }^{\mathrm{TM}}$ gel or recombinant human Collagen (rhCollagen) type I was investigated [76]. Upon mixing SHED with Puramatrix ${ }^{\mathrm{TM}}$ hydrogel for seven days and with rhCollagen type I for 14 days, and injecting the construct into roots of human premolars, the cells survived and expressed odontoblastic differentiation markers (DMP-I, DSPP, and MEPE) in vitro. Upon implanting the previous constructs subcutaneously into immunodeficient mice, pulp-like tissue with odontoblasts capable of forming neo-dentinal tubules was observed after 35 days from transplantation. The engineered pulp tissue by SHED encapsulated in Puramatrix ${ }^{\mathrm{TM}}$ or rhCollagen type I exhibited vascularization and cellularity similar to the control human pulp regarding apoptosis (detected by TUNEL) and neo-dentin deposition, as assessed by confocal microscopy [76]. These data revealed that the latter strategy might facilitate the completion of root formation in necrotic immature permanent teeth.

\section{Multidomain Peptides Hydrogels}

In 2007, an amphiphilic self-assembling peptide system termed multidomain peptides (MDP) was introduced [304]. The MDP displays distinct domains arranged in an ABA block motif that self-assemble into nanofibers, $6 \mathrm{~nm}$ in diameter, with controlled fiber length. The $6 \mathrm{~nm}$ diameter of the nanofibers created from MDPs mimics the nanoscale architecture of the natural ECM, whereby cells can bind to the fibers via adhesion molecules, but still interact with other cells in all dimensions [304]. A biodegradable variant of MDP featuring the cell adhesion motif RGD as well as an MMP-2 enzyme-cleavable site for cell-mediated degradation was then introduced [2].

MDP hydrogel has tunable viscoelastic properties, and it can be adjusted to be injectable into the root canal using a syringe, then recovers the original stiffness in situ. Investigating the regenerative potential of this variant, MDP, cellularized by incorporating DPSCs and functionalized with GFs relevant to vascularization and DPSC differentiation, including TGF- $\beta 1$, FGF-2 and VEGF, via heparin binding, revealed promising results [1]. VEGF has long been identified as a key stimulator of endothelial cell migration and proliferation [305]. TGF- $\beta 1$ is recognized as a regulator of DP proliferation, migration 
and ECM production [163], while FGF-2 is able to induce cell growth and migration without affecting cytodifferentiation [306]. These modified cellularized hydrogels, when implanted into the backs of immunocompromised mice, resulted in the formation of vascularized soft connective tissues similar to the dental pulp. The incorporated GFs were able to attract host cells into the tooth cylinders, in addition to supporting cell proliferation and differentiation when seeded with DPSCs [1]. SHED was further cultured on an MPD hydrogel to study the effect of hydrogen peroxide-induced hypoxic conditions on SHED secretome. Hypoxia-challenged SHED was able to secrete anti-inflammatory secretome into the cell culture. MPD was decellularized and lyophilized to produce a biomaterial containing anti-inflammatory bioactive molecules, in order to reduce pulpal inflammation and to promote dentin pulp complex regeneration [75].

The effect of the pretreatment of the tooth cylinders with $\mathrm{NaOCl}$, or with $\mathrm{NaOCl}$ followed by EDTA, prior to implantation of the above mentioned variant of MDP incorporating GFs and DPSCs [1] was investigated by subcutaneous implantation in the dorsal surface of mice [20]. In both groups, the implanted peptide hydrogel was degraded and replaced by a vascularized soft connective tissue similar to the dental pulp. However, noticeable differences could be observed at the cell-dentin interface where, samples pretreated with $\mathrm{NaOCl}$ showed resorption lacunae created by multinucleated cells with clastic activity, while following conditioning with EDTA, DPSCs formed an intimate association with the dentin surface, differentiated into odontoblasts-like cells expressing DSP, with cytoplasmic processes extending into the dentinal tubules [20]. Thus, for the optimization of any regenerative procedure, dentin preconditioning is a critical step that could greatly influence cellular differentiation and interaction at the dentin interface, which could impact the outcome of the REP.

Collectively, it could be concluded that self-assembled peptide hydrogels could act as injectable scaffolds for stem cell-based regenerative endodontics. Attaining physical and mechanical properties sufficient for clinical usage, besides ensuring their ability to attain full odontoblastic differentiation and tubular dentin formation clinically, are crucial prior to their clinical translation.

\subsubsection{VitroGel 3D}

VitroGel is a commercially available, xenogeneic-free, synthetic polysaccharide injectable hydrogel. VitroGel 3D is biocompatible and forms a stable gel at room temperature, and its properties can be controlled through varying the hydrogel concentration. It forms a highly porous 3D culturing system, which mimics the cellular natural environment and promotes cellular interaction [73]. The SDF-1 $\alpha$ and BMP-2 treatment of SCAP suspended in VitroGel 3D hydrogel solution effectively upregulated the early odontogenic marker RUNX-2, in addition to late odontogenic markers DMP-1, DSPP and OCN, in vitro, and these were associated with the formation of mineralized tissue surrounded by vascularized tissues in vivo following ectopic subcutaneous injection in immune-compromised mice [73].

Studies discussing natural hydrogels used for dentin-pulp complex regeneration are summarized in Table 2. 
Table 2. Synthetic hydrogels.

\begin{tabular}{|c|c|c|c|c|c|c|c|}
\hline \multirow[b]{2}{*}{ Author } & \multicolumn{7}{|c|}{ Synthetic Hydrogels } \\
\hline & Hydrogel Used & Type of Study & Hydrogel Modification & Hydrogel Properties & Cells Used & $\begin{array}{c}\text { Upregulated Biological } \\
\text { Molecules }\end{array}$ & Outcomes \\
\hline & \multicolumn{7}{|c|}{ PLA Based Polymers } \\
\hline \multirow[t]{2}{*}{$\begin{array}{l}\text { Shiehzadeh et al., } \\
2014 \text { [260] }\end{array}$} & $\begin{array}{c}\text { Polylactic } \\
\text { polyglycolic } \\
\text { acid-polyethylene } \\
\text { glycol } \\
\text { (PLGA-PEG) }\end{array}$ & Clinical trial & & & $\begin{array}{l}\text { Stem/progenitor } \\
\text { cells from the } \\
\text { apical dental } \\
\text { papilla (SCAP) }\end{array}$ & & $\begin{array}{l}\text { Biologic approach can provide a favorable } \\
\text { environment for clinical regeneration of dental } \\
\text { and paradental tissues. }\end{array}$ \\
\hline & \multicolumn{7}{|c|}{ Synthetic Self-Assembling Peptide Hydrogel (Peptide Amphiphiles) } \\
\hline & \multicolumn{7}{|c|}{ Multi Domain Self-Assembling Peptide (MDP) Hydrogel } \\
\hline $\begin{array}{l}\text { Galler et al., } \\
2011 \text { [20] }\end{array}$ & & In vivo & $\begin{array}{l}\text { MDP functionalized with } \\
\text { transforming growth factor } \\
\text { (TGF)- } \beta 1 \text {, fibroblast growth } \\
\text { factor (FGF)-2, and vascular } \\
\text { endothelial growth factor } \\
\text { (VEGF) via heparin binding }\end{array}$ & & DPSCs & & $\begin{array}{l}\text { In tooth slices, implanted hydrogel degraded } \\
\text { and replaced by a vascularized connective tissue } \\
\text { similar to dental pulp. Pretreatment of the tooth } \\
\text { cylinders with NoOCl showed resorption } \\
\text { lacunae. With NaOCl followed by } \\
\text { ethylenediaminetetraacetic acid (EDTA), } \\
\text { DPSCs differentiated into odontoblasts-like cells } \\
\text { intimately associated with the dentin surface. }\end{array}$ \\
\hline $\begin{array}{l}\text { Galler et al., } \\
2012 \text { [1] }\end{array}$ & MDP & In vivo & $\begin{array}{l}\text { MDP functionalized with } \\
\text { TGF- } \beta 1 \text {, FGF-2, and VEGF via } \\
\text { heparin binding }\end{array}$ & & DPSCs & & $\begin{array}{l}\text { Hydrogels implanted into the backs of } \\
\text { immunocompromised mice resulted in the } \\
\text { formation of vascularized soft connective tissue } \\
\text { similar to dental pulp. }\end{array}$ \\
\hline \multirow[t]{2}{*}{$\begin{array}{l}\text { Colombo et al., } \\
2020 \text { [75] }\end{array}$} & MPD hydrogel & In vitro & & & SHED & & $\begin{array}{l}\text { Decellularized and lyophilized MDP produced a } \\
\text { biomaterial containing anti-inflammatory } \\
\text { bioactive molecules that can provide a tool to } \\
\text { reduce pulpal inflammation to promote } \\
\text { dentin-pulp complex regeneration. }\end{array}$ \\
\hline & \multicolumn{7}{|c|}{ RADA16-I Hydrogels Self-Assembling Peptide } \\
\hline $\begin{array}{l}\text { Cavalcanti et al., } \\
\quad 2013 \text { [291] }\end{array}$ & $\begin{array}{l}\text { A commercial } \\
\text { self-assembling } \\
\text { peptide }\end{array}$ & In vitro & & $\begin{array}{l}\text { 0.2\% Puramatrix } \\
\quad(1 \% w / v)\end{array}$ & DPSCs & $\begin{array}{l}\text { Dentin matrix protein } \\
\text { (DMP)-1, Dentin } \\
\text { sialophosphoprotein } \\
\text { (DSPP) }\end{array}$ & $\begin{array}{l}\text { DPSCs expressed DMP-1 and DSPP after } 21 \\
\text { days culturing in dentin slices containing } \\
\text { Puramatrix }{ }^{\mathrm{TM}} \text {. The surviving dentin provided } \\
\text { signaling molecules to cells suspended in } \\
\text { Puramatrix }\end{array}$ \\
\hline
\end{tabular}


Table 2. Cont

\begin{tabular}{|c|c|c|c|c|c|c|c|}
\hline \multirow[b]{2}{*}{ Author } & \multicolumn{7}{|c|}{ Synthetic Hydrogels } \\
\hline & Hydrogel Used & Type of Study & Hydrogel Modification & Hydrogel Properties & Cells Used & $\begin{array}{l}\text { Upregulated Biological } \\
\text { Molecules }\end{array}$ & Outcomes \\
\hline $\begin{array}{c}\text { Rosa et al., } 2013 \\
{[76]}\end{array}$ & $\begin{array}{l}\text { A commercial } \\
\text { self-assembling } \\
\text { peptide }\end{array}$ & $\begin{array}{l}\text { In vitro } \\
\text { In vivo }\end{array}$ & & $0.2 \%$ Puramatrix $^{\mathrm{TM}}(1 \% w / v)$ & SHED & $\begin{array}{l}\text { DMP-I, DSPP, matrix } \\
\text { extracellular } \\
\text { phosphoglycoprotein } \\
\text { (MEPE) }\end{array}$ & $\begin{array}{l}\text { Upon mixing SHED with Puramatrix'M hydrogel } \\
\text { for } 7 \text { days and injecting the construct into roots } \\
\text { of human premolars, the cells survived and } \\
\text { expressed (DMP-I, DSPP, MEPE) in vitro. } \\
\text { Pulp-like tissue with odontoblasts able to form } \\
\text { neo-dentinal tubules was observed in vivo. }\end{array}$ \\
\hline $\begin{array}{l}\text { Dissanayaka et al., } \\
2015[276]\end{array}$ & $\begin{array}{l}\text { A commercial } \\
\text { self-assembling } \\
\text { peptide }\end{array}$ & $\begin{array}{l}\text { In vitro } \\
\text { In vivo }\end{array}$ & & $\begin{array}{c}\text { Among different } \\
\text { Puramatrix }{ }^{\mathrm{TM}}(1 \% w / v) \\
\text { concentrations, } 0.15 \% \text { was } \\
\text { the optimal. }\end{array}$ & $\begin{array}{l}\text { DPSCs and human } \\
\text { umbilical vein } \\
\text { endothelial cells } \\
\text { (HUVECs) }\end{array}$ & & $\begin{array}{l}\text { Puramatrix }{ }^{\mathrm{TM}} \text { enhanced in vitro cell survival, } \\
\text { migration and capillary formation. Co-cultured } \\
\text { groups on Puramatrix }{ }^{\mathrm{TM}} \text { exhibited more } \\
\text { extracellular matrix, mineralization and } \\
\text { vascularization than DPSC-monocultures } \\
\text { in vivo. }\end{array}$ \\
\hline $\begin{array}{l}\text { Nguyen et al., } \\
2018[88]\end{array}$ & RADA16-I & In vitro & $\begin{array}{l}\text { incorporation of dentonin } \\
\text { sequence }\end{array}$ & $\begin{array}{l}\text { Ribbonlike nanofibers with } \\
\text { height }(\sim 2 \mathrm{~nm}) \text { and width } \\
(\sim 14 \mathrm{~nm})\end{array}$ & DPSCs & & $\begin{array}{l}\text { The self-assembled peptide platform holds } \\
\text { promise for guided dentinogenesis. }\end{array}$ \\
\hline $\begin{array}{l}\text { Huang, } 2020 \\
{[280]}\end{array}$ & RADA16-I & In vitro & & $\begin{array}{c}\text { Low concentration }(0.125 \% \text {, } \\
0.25 \%) \text { caused higher cell } \\
\text { proliferation rate than high } \\
\text { concentration }(0.5 \%, 0.75 \% \text {, } \\
1 \%)\end{array}$ & $\begin{array}{l}\text { DPSCs and } \\
\text { umbilical cord } \\
\text { mesenchymal } \\
\text { stem cells }\end{array}$ & $\begin{array}{l}\text { DSPP, DMP-1, Alkaline } \\
\text { phosphatase (ALP), } \\
\text { osteocalcin (OCN) }\end{array}$ & $\begin{array}{l}\text { The co-culture groups promoted odontoblastic } \\
\text { differentiation, proliferation and mineralization. }\end{array}$ \\
\hline $\begin{array}{l}\text { Mu et al., } 2020 \\
{[87]}\end{array}$ & RADA16-I & In vitro & $\begin{array}{l}\text { incorporated with stem cell } \\
\text { factor }\end{array}$ & $\begin{array}{l}100 \mathrm{ng} / \mathrm{mL} \text { was the } \\
\text { optimum concentration of } \\
\text { the stem cell factor. } \\
\text { Nanofibers and pores } \\
\text { diameter were (10-30nm } \\
\text { and 5-200nm, respectively) }\end{array}$ & $\begin{array}{l}\text { DPSCs and } \\
\text { HUVECs }\end{array}$ & & $\begin{array}{l}\text { Stem cell factor incorporate RADA16-I holds } \\
\text { promise for guided pulp regeneration. }\end{array}$ \\
\hline $\begin{array}{l}\text { Zhu et al., } 2019 \\
\quad[142]\end{array}$ & $\begin{array}{l}\text { Cells were } \\
\text { cultured on } \\
\text { Matrigel before } \\
\text { being loaded on } \\
\text { commercial } \\
\text { self-assembling } \\
\text { peptide } \\
\end{array}$ & $\begin{array}{l}\text { In vitro } \\
\text { In vivo }\end{array}$ & & $\begin{array}{c}300 \mu \mathrm{L} \underset{1 \%}{1 \%} \text { Puramatrix }{ }^{\mathrm{TM}} \\
(1 \% w / v)\end{array}$ & $\begin{array}{c}\text { DPSCs } \\
\text { overexpressing } \\
\text { Stromal derived } \\
\text { factor-(SDF)-1 and } \\
\text { vascular } \\
\text { endothelial growth } \\
\text { factor (VEGF) } \\
\end{array}$ & SDF-1, VEGF & $\begin{array}{l}\text { Combination of VEGF- and } \\
\text { SDF-1-overexpressing DPSCs cultured on } \\
\text { Matrigel before being loaded on Puramatrix } \\
\text { enhanced the area of vascularized dental pulp } \\
\text { regeneration in vivo. }\end{array}$ \\
\hline $\begin{array}{l}\text { Xia et al., } 2020 \\
{[89]}\end{array}$ & $\begin{array}{l}\text { Self-assembling } \\
\text { peptide }\end{array}$ & $\begin{array}{l}\text { In vitro } \\
\text { In vivo }\end{array}$ & $\begin{array}{c}\text { incorporation of RGD, } \\
\text { VEGF mimetic peptide } \\
\text { sequence }\end{array}$ & $\begin{array}{c}\text { The nanofibers' diameters } \\
\text { of functionalized peptide } \\
\text { were thicker than pure RAD. } \\
\text { that the stiffness of RAD/ } \\
\text { RGD-mimicking peptide } \\
\text { (PRG)/ } \\
\text { VEGF-mimicking peptide: } \\
\text { (KLT) hydrogels was greater } \\
\text { than the others }\end{array}$ & $\begin{array}{l}\text { DPSCs and } \\
\text { HUVECs }\end{array}$ & & $\begin{array}{l}\text { Modified self-assembling peptide hydrogel } \\
\text { effectively stimulated stem cells angiogenic and } \\
\text { odontogenic differentiation in vitro and } \\
\text { dentin-pulp complex regeneration in vivo. }\end{array}$ \\
\hline
\end{tabular}


Table 2. Cont

\begin{tabular}{|c|c|c|c|c|c|c|c|}
\hline \multirow[b]{2}{*}{ Author } & \multicolumn{7}{|c|}{ Synthetic Hydrogels } \\
\hline & Hydrogel Used & Type of Study & Hydrogel Modification & Hydrogel Properties & Cells Used & $\begin{array}{l}\text { Upregulated Biological } \\
\text { Molecules }\end{array}$ & Outcomes \\
\hline \multirow[t]{2}{*}{$\begin{array}{l}\text { Liu et al., } 2017 \\
{[263]}\end{array}$} & $\begin{array}{l}\text { Poly-dimethylsiloxane } \\
\text { (PDMS) }\end{array}$ & In vitro & & $\begin{array}{c}\text { Stiffness for } 10: 1,20: 1,30: 1 \\
\text { and } 40: 1 \text { was } 135,54,16 \text { and } \\
1.4 \mathrm{kPa} \text { and roughness was } \\
55.67,53.38,50.95, \text { and from } \\
47.32 \text { to } 42.50 \mathrm{~nm} . \\
\text { Water contact angle was } 65^{\circ} \text {. }\end{array}$ & DPSCs & $\begin{array}{l}\text { osteopontin (OPN), } \\
\text { runt-related transcription } \\
\text { factor (RUNX)-2, } \\
\text { Bone morphogenetic } \\
\text { protein }\end{array}$ & $\begin{array}{l}\text { Osteogenic and odontogenic markers were } \\
\text { positively correlated to the substrate stiffness. } \\
\text { The results revealed that the mechanical } \\
\text { properties promoted the function of DPSCs } \\
\text { related to the Wnt } \beta \text {-catenin pathway. }\end{array}$ \\
\hline & \multicolumn{7}{|c|}{ Poly-N-isopropylacrylamide Gel } \\
\hline \multirow[t]{2}{*}{$\begin{array}{l}\text { Itoh et al., } 2018 \\
\text { [267] }\end{array}$} & $\begin{array}{c}\text { Poly-N- } \\
\text { isopropylacrylamide } \\
\text { (NIPAAm) }\end{array}$ & $\begin{array}{l}\text { In vitro } \\
\text { In vivo }\end{array}$ & $\begin{array}{l}\text { NIPAAm crosslinked by } \\
\text { PEG-DMA }\end{array}$ & $\begin{array}{c}\text { Decrease in wet weight } \\
\text { from } 1 \text { to } 0.18 \text { at } 508 \mathrm{C} \text {. } \\
\text { Change in surface area from } \\
1(258 \mathrm{C}) \text { to } 0.62 \text { (508 C) } \\
\text { within } 1 \mathrm{~h} \text {. High wettability. }\end{array}$ & DPSCs & $\begin{array}{l}\text { DSPP in the outer cell } \\
\text { layer, Nanog in the center } \\
\text { of the constructs }\end{array}$ & $\begin{array}{l}\text { DPSCs in the outer layer of the constructs } \\
\text { differentiated into odontoblast-like cells, } \\
\text { while DPSCs in the inner layer maintained their } \\
\text { stemness. Pulp-like tissues rich in blood vessels } \\
\text { were formed in vivo. }\end{array}$ \\
\hline & \multicolumn{7}{|c|}{ Polyethylene Glycol } \\
\hline $\begin{array}{l}\text { Komabayashi } \\
\text { et al., 2013 } \\
\text { [275] }\end{array}$ & PEG & In vitro & $\begin{array}{c}\text { PEG-maleate-citrate } \\
\text { (PEGMC) }(45 \% \text { w/v), acrylic } \\
\text { acid (AA) crosslinker }(5 \% \\
w / v), 2,2^{\prime}-\text {-Azobis } \\
\text { (2-methylpropionamidine) } \\
\text { dihydrochloride (AAPH) } \\
\text { photo-initiator }(0.1 \% w / v),\end{array}$ & $\begin{array}{l}\text { Optimum cell viability with } \\
\text { exposure time of } 30 \mathrm{~s} \text { with a } \\
\text { monomer and AAPH } \\
\text { concentration of } 0.088 \% \text { and } \\
\text { up to } 1 \% \text {, respectively } \\
\text { VitroG }\end{array}$ & L929 cells & & $\begin{array}{c}\text { Cell viability remained up to } 80 \% \text { after } 6 \mathrm{~h} \text {. } \\
\text { Controlled Ca2+ release was attained. } \\
\text { The viscosity and injection ability into plastic } \\
\text { root canal blocks were confirmed in a dental } \\
\text { model. }\end{array}$ \\
\hline $\begin{array}{l}\text { Xiao et al., } \\
2019 \text { [73] }\end{array}$ & Vitrogel & $\begin{array}{l}\text { In vitro } \\
\text { In vivo }\end{array}$ & & $\begin{array}{l}\text { VitroGel diluted with } \\
\text { deionized water 1:2. }\end{array}$ & SCAP & $\begin{array}{l}\text { RUNX-2,DMP-1, DSPP, } \\
\text { OCN }\end{array}$ & $\begin{array}{l}\text { VitroGel 3D promoted SCAP proliferation and } \\
\text { differentiation. SDFr-1 } \alpha \text { and BMP-2 } \\
\text { co-treatment induced odontogenic } \\
\text { differentiation of human SCAP cultured in the } \\
\text { VitroGel 3D } \\
\text { in vitro and in vivo }\end{array}$ \\
\hline
\end{tabular}




\subsection{Hybrid Hydrogels}

Based on the polymer's nature when involved in hydrogel synthesis, hybrid hydrogels incorporate synthetic and natural polymeric chains, combining their characteristics and advantages and alleviating their drawbacks. Synthetic polymers provide ease of manufacturing on a large scale, and could be mechanically tuned and processed into the desired shapes at a molecular level by the polymerization and crosslinking, while natural polymers evoke an active cellular response, and provide biological recognition and cell-triggered remodeling [307]. Hybrid hydrogels are mainly composed of proteins and peptides enclosed into synthetic polymers via conjugation or polymerization, which make them compatible for in vitro studies and in vivo applications [308]. Hybrid hydrogels have become a direct approach to creating bioactive hydrogel scaffolds for dentin-pulp tissue engineering $[307,309]$. They can enhance cell adhesion, organization, and cell-cell interactions, which allows the fabrication of tissue constructs with improved cellular organization, mechanical integrity and electroactivity [310,311]. Hybrid hydrogel polymers involved in dentin-pulp regeneration include alginate/laponite hydrogel [56] as well as PEG-modified natural polymers, such as heparin, dextran, HA, fibrinogen and albumin [262].

\subsubsection{Alginate/Laponite Hydrogel}

RGD alginate is a commercially available alginate modified through the incorporation of the RGD cell-binding sequence. Alginate/laponite hybrid injectable hydrogel microspheres, formed of RGD alginate and nano-silicate laponite, were successfully used as a carrier for VEGF and DPSCs. The resulting hydrogel was biocompatible, biodegradable, and supported DPSCs odontogenic differentiation and the expression of ALP, DMP-1, and Col-I in vitro. Injection of the alginate/laponite hydrogel loaded with DPSCs and VEGF into root segments followed by subcutaneous ectopic implantation in nude mice resulted in the formation of vascularized pulp-like tissues with a cell layer lining the dentin walls in vivo. The incorporation of laponite allowed the tunability of the hydrogel's mechanical property and VEGF release [56].

\subsubsection{PEG-Modified Natural Polymers}

PEG was used in conjugation with natural polymers such as alginate [312], fibrinogen [313], fibrin [66] HA and gelatin [314] for potential dentin-pulp complex regeneration, with promising results. PEG alginate hybrid hydrogel was evaluated for the local delivery of DPSCs and FGF for pulp regeneration in vitro and in vivo. A stereolithography 3D printed stem cell-responsive PEG diacrylate and sodium alginate composite hydrogel system (PEGDA/SA), constructed at different mass ratios of PEGDA to SA (25:1, 20:1 and 15:1), was loaded with DPSCs and basic FGF (PEGDA/SA-bFGF). The DPSCs-loaded PEGDA/SA-bFGF hydrogels exhibited high cell compatibility and supported cell proliferation, irrespective of their concentration ratios in vitro. The hydrogel system also successfully formed a well-organized pulp structure in vivo after four weeks of implantation in an immunodeficient mice model, when used at ratios of 20:1 and 15:1. The DPSCs-loaded PEGDA/SA construct without FGF addition, on the other hand, failed to form a pulp structure, while a partial loose connective tissue formation was observed with the mass ratio of 25:1 [312].

The PEG fibrinogen (PF) hydrogel composed of PEG side chains conjugated to a bioactive fibrinogen backbone was also investigated for potential dentin-pulp complex regeneration. PF is an injectable hydrogel characterized by having a tunable mechanical property which can be adjusted through controlling the degree of crosslinker concentration. PF hydrogels were cytocompatible and supported DPSCs odontogenic differentiation and mineralization. DPSCs' morphology, odontogenic genes expression (Col I, DSPP, DMP-1, OC) and mineralization potential were strongly dependent on crosslinker concentration $(0,0.5,1.5$, and $2.5 \% w / v)$ and matrix stiffness. The highest odontogenic gene expression and mineralization potential, with lesser proliferation potential, was recorded with the hydrogel with higher crosslinker concentration [313]. 
The compatibility of PEGylated fibrin scaffold was examined on dental stem/progenitor cells SHED, DPSCs and PDLSCs. Dental stem/progenitor cells were cultured on PEGylated scaffolds and subjected to osteogenic induction for four weeks. An upregulation in ALP activity and osteoblast and odontoblast differentiation genes, including Col I, Col III, MMP-2, BSP, OCN and RUNX 2, were observed. The gene expression profile was variable between different cell types, whereby SHED and PDLSCs exhibited higher expressions of collagen, while DPSCs and PDLSCs expressed higher levels of late markers of differentiation as compared to SHED, which reflected the immaturity of the SHED population, while dentin-specific markers (DSPP and DMP-1) increased in the pulp-derived stem/progenitor cells (SHED and DPSCs). Further, SHED displayed a slightly higher proliferation rate upon culturing on either PEGylated fibrin or Col I scaffolds, as compared to Puramatrix ${ }^{\mathrm{TM}}$. Histologic analysis for in vitro cultures revealed the degradation of fibrin, the production of a collagenous matrix, and mineral deposition. SHED was selected to be loaded onto a PEGylated fibrin scaffold, incorporated in dentin disks and then implanted in immunocompromised mice. After five weeks of in vivo transplantation, the fibrin matrix was degraded and replaced by a vascularized soft connective tissue similar to dental pulp [66]. Therefore, PEGylated fibrin appeared to be a promising biomaterial for pulp tissue regeneration, since it supported cell encapsulation and promoted the growth and differentiation of dental stem cells, and can be inserted into tiny defects.

HyStem-C is a commercially available injectable hydrogel comprised of HA crosslinked with synthetic PEGDA and thiol-reactive gelatin. HyStem-C has tunable mechanical properties through changing the concentration of its components to mimic the desired tissue criteria, which allows for promoting cell viability and spreading [315]. Accordingly, HyStem-C's components were altered to improve its mechanical strength, DPSCs biocompatibility and injectability into the root canal [314]. Firstly, PEGDA were modified by an added disulfide bond, giving rise to PEGSSDA to enable non-enzymatic cell recovery. Secondly, variable volume ratios of thiolated HA:thiolated gelatin (1:0, 3:1, 1:1, and 1:3) were utilized corresponding to HA:gelatin ratios (100:0 to 25:75) in order to encourage cell spreading. Fibronectin was subsequently added in 1:1 $(v / v)$ ratios of thiolated HA and gelatin solutions, to examine the effects of ECM proteins on human DPSCs proliferation and migration. Finally, PEGDA $3400(2.0 \% w / v)$ was added to the HA-gelatin-Fn mixture in a 1:4 volume ratio. Interestingly, the hydrogel gelation time decreased as the PEGSSDA crosslinker concentration increased. The PEGSSDA-HA-gelatin was biocompatible with human DPSCs, as increasing the ratios of HA:gelatin enhanced cell viability for 14 days. Additionally, cell proliferation with added fibronectin increased considerably with time in PEGDA-HA-gelatin hydrogels, while cell spreading increased at fibronectin concentrations of $0.1 \mu \mathrm{g} / \mathrm{mL}$. The cell adhesion signaling cascades mediated by fibronectin binding seemed to allow cells to attach to the ECM and function well. Human DPSCs proliferation increased with increased fibronectin concentrations. Although the human DPSCs embedded in the PEGSSDA-HA-gelatin hydrogels appeared to spread early, the migration potential seemed to decrease after four days, which proved the key role of fibronectin in DPSCs spreading [314]. Both collagen and fibronectin are expressed in native dental pulp, but the mutual integrin-binding sites' effects on human DPSCs fate in injectable hybrid scaffolds need further clarification. Studies discussing natural hydrogels used for dentin-pulp complex regeneration are summarized in Table 3. 
Table 3. Hybrid hydrogels.

\begin{tabular}{|c|c|c|c|c|c|c|c|}
\hline \multirow[b]{2}{*}{ Author } & \multicolumn{7}{|c|}{ Hybrid Hydrogels } \\
\hline & Hydrogel Used & Type of Study & Hydrogel Modification & $\begin{array}{c}\text { Hydrogel } \\
\text { Properties }\end{array}$ & Cells Used & $\begin{array}{l}\text { Upregulated Biological } \\
\text { Molecules }\end{array}$ & Outcomes \\
\hline & \multicolumn{7}{|c|}{ Alginate/laponite hydrogel } \\
\hline Zhang et al., 2020 [56] & $\begin{array}{l}\text { Alginate/laponite } \\
\text { hydrogel }\end{array}$ & $\begin{array}{l}\text { In vitro } \\
\text { In vivo }\end{array}$ & $\begin{array}{l}\text { Arginine-glycine-aspartic } \\
\text { acid (RGD) modified } \\
\text { alginate and nano-silicate } \\
\text { laponite hydrogel } \\
\text { microspheres, } \\
\text { encapsulating human } \\
\text { dental pulp stem cells } \\
\text { (DPSCs) and vascular } \\
\text { endothelial growth factor } \\
\text { (VEGF). }\end{array}$ & $\begin{array}{l}\text { The RGD-Alg had } 55 \% \\
\text { degradation rate and the } \\
\text { RGD- alginate/laponite } \\
\text { exhibited } 45 \% \text { while pure } \\
\text { alginate degraded only } 20 \% \\
\text { after } 28 \text { days. }\end{array}$ & DPSCs & $\begin{array}{l}\text { Alkaline phosphatase } \\
\text { (ALP), Dentine matrix } \\
\text { protein } 1 \text { (DMP-1), } \\
\text { collagen I (Col-I) }\end{array}$ & $\begin{array}{c}\text { Hybrid RGD modified } \\
\text { alginate/laponite hydrogel } \\
\text { microspheres has a promising } \\
\text { potential in vascularized dental pulp } \\
\text { regeneration. }\end{array}$ \\
\hline & \multicolumn{7}{|c|}{ PEG-modified natural polymers } \\
\hline Galler et al., 2011 [66] & PEGylated fibrin & $\begin{array}{l}\text { In vitro } \\
\text { In vivo }\end{array}$ & $\begin{array}{l}\text { PEGylated fibrinogen } \\
\text { with added thrombin. }\end{array}$ & $\begin{array}{c}\text { Carboxylated } \\
\text { N-hydroxysulfosuccinimide- } \\
\text { active ester polyethylene } \\
\text { glycol (PEG) (MW = 3400 Da) } \\
\text { added to } 40 \mathrm{mg} / \mathrm{mL} \text { of bovine } \\
\text { fibrinogen in TRIS- saline at a } \\
\text { molar ratio of } 10: 1 . \\
\text { Equal volume of thrombin } \\
\text { (200 U/mL in } 40 \mathrm{mM} \mathrm{CaCl2}) \\
\text { was added }\end{array}$ & $\begin{array}{l}\text { Stem cells isolated from } \\
\text { human exfoliated } \\
\text { deciduous teeth (SHED), } \\
\text { DPSCs, } \\
\text { periodontal ligament } \\
\text { stem cells (PDLSCs), } \\
\text { bone marrow } \\
\text { mesenchymal stem cells } \\
\text { (BMMSCs) }\end{array}$ & $\begin{array}{l}\text { Col I, Col III, matrix } \\
\text { metalloproteinase } \\
\text { (MMP-2), } \\
\text { bone Sialoprotein (BSP), } \\
\text { osteocalcin (OCN), } \\
\text { runt-related transcription } \\
\text { factor -2 (RUNX2), dentin } \\
\text { sialophosphoprotein } \\
\text { (DSPP), DMP-1 }\end{array}$ & $\begin{array}{l}\text { ALP activity and osteoblastic and } \\
\text { odontoblast differentiation genes } \\
\text { were higher in dental stem cells than } \\
\text { BMMSCs. SHED and PDLSCs } \\
\text { exhibited high expression of collagen, } \\
\text { while DPSCs and PDLSCs expressed } \\
\text { high levels of differentiation late } \\
\text { markers. In vivo, fibrin matrix } \\
\text { degraded and replaced by } \\
\text { vascularized connective tissue. }\end{array}$ \\
\hline Lu et al., 2015 [313] & PEG fibrinogen & In vitro & $\begin{array}{l}\text { PEG fibrinogen with } \\
\text { variable amounts of } \\
\text { polyethylene glycol } \\
\text { diacrylate (PEGDA) }\end{array}$ & $\begin{array}{c}\text { Increase of PEGDA } \\
\text { crosslinker allows for higher } \\
\text { modulus but longer times of } \\
\text { crosslinking and less swelling } \\
\text { ratio }\end{array}$ & DPSCs & Col I, DSPP, DMP-1, OCN & $\begin{array}{l}\text { Odontogenic genes expressions and } \\
\text { mineralization were correlated to the } \\
\text { hydrogel crosslinking degree and } \\
\text { matrix stiffness }\end{array}$ \\
\hline Jones et al., 2016 [314] & $\begin{array}{l}\text { HyStem-C is a } \\
\text { commercial } \\
\text { hydrogel } \\
\text { hyaluronic acid } \\
\text { (HA)- PEGDA } \\
\text {-gelatin } \\
\end{array}$ & In vitro & $\begin{array}{l}\text { Polyethylene glycol } \\
\text { diacrylate with an added } \\
\text { disulfide bond } \\
\text { (PEGSSDA) with an } \\
\text { added disulfide bond. }\end{array}$ & $\begin{array}{c}\text { Hydrogel gelation time } \\
\text { decreased as the PEGSSDA } \\
\text { crosslinker concentration } \\
(w / v) \text { increased from }(0.5 \% \text { to } \\
8.0 \%)\end{array}$ & DPSCs & & $\begin{array}{l}\text { The PEGSSDA-HA-Gn was } \\
\text { biocompatible with human DPSCs. } \\
\text { Cell proliferation and spreading } \\
\text { increased considerably with adding } \\
\text { fibronectin to PEGDA-HA-Gn } \\
\text { hydrogels. }\end{array}$ \\
\hline Feng et al., 2020 [312] & $\begin{array}{c}\text { Polyethylene } \\
\text { glycol } \\
\text { diacrylate } \mid \text { sodium } \\
\text { alginate } \\
\text { (PEGDA/SA) }\end{array}$ & $\begin{array}{l}\text { In vitro } \\
\text { In vivo }\end{array}$ & $\begin{array}{c}\text { PEGDA/SA loaded basic } \\
\text { fibroblast growth factor } \\
\text { (bFGF) } \\
\text { (PEGDA/SA-bFGF) }\end{array}$ & & DPSCs & & $\begin{array}{l}\text { Reduction of mass ratio of } \\
\text { PEGDA/SA to 20:1 15:1 resulted in } \\
\text { the formation of a well-organized } \\
\text { pulp structure after implantation }\end{array}$ \\
\hline
\end{tabular}




\section{Comparing Natural and Synthetic Classes of Hydrogels}

Natural hydrogels are biocompatible, biodegradable and bioactive, can mimic cells' ECM, and promote cell adhesion, proliferation and differentiation, besides being not associated with sever inflammatory responses [316,317]. Natural hydrogels are also characterized by having bioactive molecules which can promote cell proliferation and function [318] in addition to their innate content of cell adhesion molecules, which can promote cellular adhesion and migration [319]. However, natural hydrogels can carry the risk of disease transmission and immune reaction, and may display batch to batch variations [7,320-322] in addition to their poor mechanical properties [322]. Synthetic hydrogels were developed, aiming to overcome natural hydrogel's limitations. They are characterized by ease of standardization, large-scale production, and tunable mechanical properties, degradation rate and microstructure. They also carry no risks for disease transmission $[7,321,322]$. They also have a higher water retention capacity, in addition to longer shelf-life [323]. Unfortunately, synthetic hydrogels are not biologically active, and often require the incorporation of biologically active molecules and cell-binding sequences to improve cellular response [7,324].

Different synthetic and natural hydrogels were tested for their suitability in engineering dental pulp. Two classes of synthetic materials, PEG and self-assembled peptides, in addition to two natural hydrogel materials, fibrin and Col I, were tested for their biocompatibility with primary human DPSCs [325]. Three different PEG-based materials were developed-a chemically curing hydrogel (PEGchem), a light-curing hydrogel (PEGlight), and a biomimetic hydrogel (PEGbio) that was functionalized with a cell adhesion motif (Arg-Gly-Asp-Cys; PEG5k-RGDC-acrylamide) in addition to an MMP-2 sensitive enzyme-cleavable site. Two types of self-assembled peptides have also been used-a custom made self-assembling peptide, with a defined stiffness and a modified mode of gelation with a cell adhesion motif and an MMP-2-cleavable site (SAPbio), and a commercially available self-assembling peptide (Puramatrix ${ }^{\mathrm{TM}}$ ) (SAPcom). The primary DPSCs cultures were established from extracted third molar tooth germs validated through being STRO-1-positive, in addition to being susceptible to adipogenesis, osteogenesis and chondrogenesis differentiation. The cell viability of the DPSCs incorporated into test materials was assessed using MTT assays over two weeks. Four out of the seven materials were chosen for an in vivo model for dental pulp regeneration: fibrin, PEGchem, PEGbio and SAPbio. Selected test materials were loaded with dentin matrix proteins that had been filtrated to attain a $500 \mathrm{pg} / \mathrm{mL}$ concentration of TGF- $\beta 1$, then seeded with cells, injected into human tooth roots and finally transplanted subcutaneously into immunocompromised mice for four weeks. Distinct differences were revealed between different types of scaffolds, where in vitro cell viability was considerably higher in natural materials as compared to synthetic ones. Furthermore, significant differences regarding scaffold degradation, odontoblast-like cell differentiation, tissue formation and vascularization were revealed in vivo [325]. These data provide evidence that natural materials, especially fibrin, appeared ultimately suitable for pulp tissue regeneration, regarding the efficient enhancement of odontoblastic differentiation at the cell-dentin interface. Study highlighting and comparing natural and synthetic hydrogels used for dentin-pulp complex regeneration are summarized in Table 4.

Table 4. Comparing natural and synthetic hydrogels.

\begin{tabular}{|c|c|c|c|c|c|c|}
\hline \multicolumn{7}{|c|}{ Comparing Natural and Synthetic Hydrogels } \\
\hline $\begin{array}{c}\text { Galler et al., } \\
2018 \text { [325] }\end{array}$ & $\begin{array}{c}\text { - PEG } \\
\text { - Self-assembling } \\
\text { peptide (SAPbio) } \\
\text { and } \\
\left.\text { Puramatrix }^{\mathrm{TM}}\right)\end{array}$ & $\begin{array}{l}\text { In vitro } \\
\text { In vivo }\end{array}$ & $\begin{array}{l}\text { - PEG was modified to be } \\
\text { chemically cured } \\
\text { (PEGchem) or light-cured } \\
\text { (PEGlight), } \\
\text { - Biomimetic hydrogels } \\
\text { (PEGbio) modified by cell } \\
\text { adhesion motif and MMP-2. } \\
\text { - Self-assembling peptide } \\
\text { (SAPbio) modified by cell } \\
\text { adhesion motif and MMP-2. }\end{array}$ & DPSCs & TGF- $\beta 1$ & $\begin{array}{c}\text { In vitro viability was } \\
\text { higher in natural } \\
\text { materials. Scaffold } \\
\text { degradation, } \\
\text { odontoblast-like cell } \\
\text { differentiation, tissue } \\
\text { formation and } \\
\text { vascularization were } \\
\text { higher in natural } \\
\text { materials in vivo. }\end{array}$ \\
\hline
\end{tabular}




\section{Clinical Application of Different Hydrogels for Dentin-Pulp Complex Regeneration}

The successful clinical translation of a hydrogels scaffold for dentin-pulp complex regeneration has been reported. Gelatin hydrogel loaded with FGF was used for apexogenesis of immature, non-vital, permanent maxillary anterior teeth in human patients. Following access cavity and root canal mechanical preparation, intracanal bleeding was induced through over instrumentation; this was followed by injecting the hydrogel into the root canal. Follow-up radiographs revealed an increase in root length and width with a decrease in apical diameter, confirming continuation of root development [85]. Polylactic-polyglycolic acid (PLGA) and PEG co-polymer-based hydrogel were also successfully used for the apexogenesis of the lower left second premolar with immature apex and thin radicular dentinal walls in a 20-year-old patient. The access cavity was prepared and the root canal was irrigated and dried. PEG-PLGA hydrogel loaded with autogenous SCAP was injected into the canal, and the access cavity was sealed with a restoration. Three months post-operation, the tooth was asymptomatic, and radiographic examination revealed apical closure and thickening of the dentinal walls [260]. Furthermore, an injectable mixture combining human-treated dentin matrix and alginate was used as a pulp-capping agent for dentin regeneration clinically. This scaffold showed no difference compared with Biodentin and the mineral trioxide aggregate when used as direct pulp capping materials clinically and histologically. However, there was a difference in the thickness and quality of the hard tissue formed on the exposed pulps with human-treated dentin matrix, showing a positive tendency for dentin regeneration and conservation of pulp vitality [248].

Platelet-rich fibrin (PRF) is considered to be a natural multifunctional hydrogel with promising application in tissue regeneration [326]. Fibrin gel is formed as plasma fibrinogen, and is activated by protease thrombin during the clotting process to polymerize into a 3D network of branching fibers, giving rise to hydrogels with high elastic moduli [327]. Autologous PRF is prepared through the centrifugation of patients' blood. It allows the local delivery of growth factors, including PDGF, VEGF, TGF- $\beta$, BMP and cells, including platelets and leukocytes, which promote tissue healing and regeneration [327]. A case study reported successful pulp regeneration with DPSCs-loaded PRF in a mature permanent tooth. Autologous DPSCs isolated from extirpated autologous inflamed dental pulp were loaded on autologous PRF in a lower premolar tooth with irreversible pulpitis, following access cavity and mechanical preparation of the root canal. The tooth was asymptomatic during follow up visits, with no signs of pulpal inflammation; pulp testing confirmed the presence of vital dental pulp and radiographic evaluation revealed no periapical pathosis [249]. A randomized controlled trial further evaluated the efficacy of PRF for the apexogenesis of necrotic permanent maxillary incisors with immature roots. Patients recruited in the study with necrotic permanent maxillary incisors were subjected to access cavity preparation, then roots were mechanically prepared, followed by the intracanal application of autologous PRF prepared by centrifugation of the patients' blood in the absence of anticoagulants. Follow-up radiographs demonstrated periapical healing, apical closure, root lengthening and thickening of dentinal wall. The regeneration potential of PRF was superior to that of the placentrex and chitosan scaffolds [250].

\section{Physical and Chemical Properties of the Hydrogel that Affect Cellular Behavior in Dentin-Pulp Regeneration}

For REP, the physical, chemical and structural properties of the polymer are of paramount importance in dictating the cellular behavior, and hence the final biological outcome.

\subsection{Bioactivity of the Polymer}

The utilization of naturally occurring matrices, such as decellularized dentin matrix, $\mathrm{pECM}$ or naturally derived polymers, is a promising approach. They are bioactive, and preserve the natural cell-adhesive motifs (RGD) and MMP-binding sites that are important for cellular interaction and enhancing cell viability, proliferation, and differentiation [81,92]. In decellularized matrix hydrogel derived from human dental pulp, the protein components of this decellularized biomaterial were 
found to be responsible for the regulation of cellular behaviors, such as cell adhesion, proliferation and migration [247]. Optimizing the wettability of hydrophobic polymers is essential in order to enhance cell adhesion. Altering the water contact angle of the PDMS material surface from $110^{\circ}$ to $65^{\circ}$ was employed to optimize cell attachment [328].

\subsection{Hydrogel Forming Ability}

The hydrogel-forming properties of the employed polymer are crucial. The gelation process should be carried out using non-toxic solvents and under physiological conditions (in terms of $\mathrm{pH}$ and temperature), to allow easy cell encapsulation and entrapment without negatively impacting cell viability. Such hydrogel formulations offer great potential for cell and/or drug delivery.

\subsection{Concentration of the Monomer}

Tailoring the polymeric hydrogels' mechanical properties can be done by varying different parameters, such as the polymer molecular weight, source, concentration and chemical modifications, and/or the type and degree of crosslinking [159].

Varying the monomer concentration and oligomer:monomer ratio allows for tuning the mechanical properties to cover a range of stiffnesses to match various tissues, which modulate cell-matrix interactions and could specify stem cell lineage. The stiffness and microstructure of collagen matrices could be tailored by modulating collagen concentration and ratio $[61,101]$. The stiffness of the matrix also affects the rate of cell proliferation, whereby cell proliferation was shown to be higher on the compliant matrix, as compared to the stiffer matrix. This might be explained by the longer time taken by the cells to penetrate the stiffer matrices [61]. Stiffness also affect cytoskeletal organization and cell shape; stiffer collagen matrices $(800 \mathrm{~Pa}$ ) decreased the cell spreading and actin fiber organization, while compliant collagen (235 Pa) supported the growth of elongated DPSCs [61]. Moreover, GelMA hydrogels of 10 and $15 \%(w / v)$ concentrations had smaller pore sizes than 5\% GelMA, thus indicating the formation of denser crosslinked networks in hydrogels with higher concentrations [68].

In PDMS substrates, the stiffness of substrates increased with reducing the liquid oligomeric base to agent-curing proportions [263]. The mechanical properties of the hydrogel influence the cell morphology, which subsequently influences cell function. Increased substrate stiffness enhances DPSCs osteoblastic/odontogenic differentiation and proliferation, as evident by the increased expression of marker genes and proteins related to the odontogenic differentiation of DPSCs. The potential mechanism of stiffness-dependent osteogenic/odontogenic differentiation and proliferation might be linked to the canonical Wnt pathway [263].

\subsection{Concentration of the Crosslinker}

Controlling the crosslinker concentration and crosslinking density allows for tailoring the mechanical properties [96]. The enhanced physical properties induced via crosslinking improve the mechanical properties, such as stiffness. Modulating substrate stiffness exerts biomechanical regulatory forces, where stiffer matrices constrain the movement of tissues and cells, slow cellular movement, and the cells exert higher traction forces on their substrates, which are dissipated within the cell, and might change the protein conformation connecting the cytoskeleton and matrix $[97,98]$. Thus, increased stiffness and compressive strength could impact hDPCs count and odontogenic differentiation [60]. In 1,4-butanediol diglycidyl ether (BDDE)-crosslinked HA gels (HAGs), the higher the concentration of BDDE, the more rigid the hydrogel, as more crosslinking points are yielded. The higher the rigidity of the hydrogel the lower the swelling ratio and the higher the $G^{\prime}$ and $G^{\prime \prime}$ value [193]. Increasing the crosslinking density results in a reduction in pore size, while a higher BDDE concentration also resulted in the lesser degree of interconnectivity [193]. In $\mathrm{HA} /$ cellulose nanocrystals/platelet lysate $(\mathrm{CNC} / \mathrm{PL})$, the incorporation of a-CNCs in the HA matrix led to stiffer hydrogels and induced a reinforcement effect by acting as effective junction elements [194]. $\mathrm{CNCs}$ incorporation increased the degree of crosslinking, and consequently decreased the degradation 
rate and swelling profiles. Furthermore, CNCs incorporation resulted in a slower and longer release of the GFs by prolonging the entrapment time of the GFs [194].

Increasing the concentration of the PEGDA crosslinker in the PF hydrogels resulted in increasing the mean shear storage modulus. Furthermore, the gel point of the hydrogels ranged from 11.4 to 23.4 $\mathrm{s}$ with increasing amounts of PEGDA. The addition of PEGDA crosslinker significantly decreased the swelling ratio from $42 \pm 7.5$ in PF-0 to $29.3 \pm 0.8$ in PF-2.5 hydrogel. These results indicate that the increase in PEGDA crosslinker allows for a higher degree of PF hydrogel crosslinking, which results in higher modulus but also requires longer times for completion of the crosslinking process. These results indicate that an inverse correlation exists between the amount of additional PEGDA and the swelling ratio, whereby hydrogels with higher PEGDA concentration induce less swelling due to the higher network crosslinking degree with a smaller mesh size [313].

$\mathrm{HA} / \mathrm{CNC} / \mathrm{PL}$ hydrogels were produced through hydrazone crosslinking chemistry between hydrazide/amine and aldehyde groups. The CNCs content in injectable HA/CNC/PL hydrogel showed a positive effect on the gelation time of the hydrogels; the decrease in gelation time was proportional to the amount of the available aldehyde moieties for crosslinking incorporated through a-CNCs [194]. A shortened setting time and faster conversion into the gel state has been shown to enhance cellular adhesion, as compared to the sol state [60].

\subsection{Polymer Degradability}

Varying the polymer molecular weight, besides altering its mechanical properties, also affects the polymer degradation. The molecular weights of the HA polymers significantly affected the dynamic degradation, swelling, and rheological properties of the hydrogels, whereby the 18-kDa HA hydrogels degraded faster and lost their stiffness $\left(\mathrm{G}^{\prime}\right)$ quicker than the 270-kD HA hydrogels. The degradation rate decreased and the storage modulus $\left(G^{\prime}\right)$ increased with the increase in the molecular weight of HA, while the $G^{\prime}$ decreased with the degradation of the hydrogels [196].

The modification of non-degradable polymers is essential to allow cells/drug release, and allow replacement by regenerating the tissue. Alginates are non-biodegradable in mammals, due to a lack of alginase enzymes. The partial oxidation of alginate chains using sodium periodate makes them biodegradable, and promotes the hydrolysis of alginate in aqueous solutions [127,161]. A biodegradable variant of MDP was designed via incorporating the cell adhesion motif RGD and matrix metalloprotease-2 (MMP-2) enzyme-cleavable site for cell-mediated degradation [2].

\subsection{Biofunctionalization}

Some of the widely used polymers are not bioactive, such as alginates and synthetic polymers; they lack cell-adhesion motifs, which affects cellular adhesion and subsequent cellular processes. The biofunctionalization of such polymers is a common way to improve their bioactivity. As discussed earlier, the coupling of an entire protein is difficult to control and may trigger an unwanted immune response, and proteins are subjected to proteolytic degradation. Thus, the immobilization of cell recognition motifs, such as RGD, is a more common way to improve the polymer's ability to interact with cells $[2,83,94,165]$.

Puramatrix ${ }^{\mathrm{TM}}$ is a peptide-based synthetic hydrogel, consisting of alternative hydrophilic and hydrophobic amino acids arginine (R), alanine (A), and aspartic acid (D), resembling the RGD motif found in many extracellular matrix proteins such as fibronectin [329].

BMP, VEGF, FGF-2 and TGF are the principle morphogens that are being used frequently in conjunction with dental stem cells to induce a variety of cellular activities and induce various tissue structures, even when used at low very concentrations [1]. VEGF and FGF were shown to enhance angiogenesis and neovascularization in severed human DP [24], while BMPs are suggested to induce new dentin formation [25]. Dentin-derived BMP2 has been demonstrated to play a key role in inducing the differentiation of dental stem cells into odontoblasts [330]. Growth factors might be added to the matrix to supplement the biophysical factor-induced differentiation of DPSCs [24]. 
VEGF/chitosan/ $\beta$-glycerophosphate (CS/ $\beta$-GP) hydrogel was able to provide the sustained release of VEGF into the surroundings, which promoted the activity and odontogenic differentiation of DPSCs [180].

\subsection{Rheological Properties}

The polymeric hydrogel's injectability is greatly influenced by the hydrogel viscosity evaluated by storage modulus $\left(\mathrm{G}^{\prime}\right)$ and loss modulus $\left(\mathrm{G}^{\prime \prime}\right)$. Indeed, a relatively low viscosity of the formulation is necessary to allow for the easy injection into an emptied endodontic space with a millimeter-range diameter [123]. The viscosity of the polymer solution increases with polymer molecular weight, and the polymer formulation must remain sufficiently fluid to preserve the injectability of the final formulations [123]. In 3D bioprinting, the printability of cell-laden hydrogel bioinks depends mainly on the material's rheological properties, especially prior to crosslinking. The rheological properties of importance include the material's viscosity and shear-thinning properties (or decreases in viscosity as a function of shear rate) [168]. In addition, DPSCs morphology and stemness were shown to be strongly correlated with the rheological properties of the 2-Aminoethyl methacrylate (AEMA-HA) hydrogels. When the hydrogels' storage modulus was higher than $486 \mathrm{~Pa}$, the DPSCs had a spherical morphology and increased stemness [196]. An appropriate "setting/gelation time" was deemed necessary; not too fast so as to enable the accurate injection of the formulation into the endodontic space, and not too long to allow for the rapid implementation of the crown filling [123]. In GC-TRS hydrogel scaffold, the glycol chitin gelation rate was very high when the temperature was raised above the body temperature, and exhibited fast sol-gel transition kinetics in vivo, which is highly desirable for injectable hydrogel scaffolds [179]. Crosslinking affected the rheological properties of the polymeric hydrogels; GelMA exhibited a $\sim 2 \mathrm{kPa} \mathrm{G}^{\prime}$ before UV crosslinking and $\sim 4 \mathrm{kPa}$ after UV crosslinking [65]. Both $\mathrm{G}^{\prime}$ and $\mathrm{G}^{\prime \prime}$ increased as a function of time after raising the temperature of the buffered solution from $15 \mathrm{C}$ to $37^{\circ} \mathrm{C}[245,246]$.

\subsection{Network Structure}

Three-dimensional matrices recover the cell-cell cross talks and cell-matrix interactions existing in vivo in the in vitro culture environment $[104,331]$. The scanning electron microscopic characterization of the decellularized matrix hydrogel derived from human dental pulp exhibited an ECM-like nanofibrous structure [247]. MDP, a self-assembling peptide, self-assembles into nanofibers $6 \mathrm{~nm}$ in diameter, which mimic the nanoscale architecture of the natural ECM, enhancing cell-binding to the fibers via adhesion molecules and cellular interaction in all dimensions [304]. Puramatrix ${ }^{\mathrm{TM}}$ is another synthetic peptide hydrogel, which in the presence of physiological buffer spontaneously organizes into a membranous 3D hydrogel that exhibits a nano-fibrous structure with an average pore size of 50-200 nm [329]. Lyophilized chitosan hydrogels exhibited a spongy and porous microstructure, with an average pore diameter range of 100 to $200 \mu \mathrm{m}$, which allowed DPSC adhesion with the embedded cellular synapses in the hydrogels [180]. Crosslinked silated hydroxypropylmethylcellulose (Si-HPMC) hydrogel revealed a nano-porous macromolecular structure with an average pore diameter of $10 \mathrm{~nm}$, which is greater than the diameter of the proteins, allowing the liberation of proteins and growth factors [226].

$3 \mathrm{D}$ bioprinting, a relatively novel rapid prototyping technology, allows for precise control of the external architecture and internal microstructure of the scaffolds, and the scaffold's pore interconnectivity and pore diameter. Such printed matrices attempt to mimic the in vivo cellular environment for improved cellular interactions and desirable biological response [168,169].

Incorporating bioactive glass nano-particles into thermo-responsive injectable hydrogels also provided a large surface area with highly charged surfaces, so as to increase bioactivity, accompanied by the highly porous structure of the scaffold. This modification offers a large surface area and interconnected pores for the ingrowth of the cells [228]. 


\section{9. $\mathrm{pH}$ of the Polymer Solution}

The $\mathrm{pH}$ of the employed polymer solution must be close to neutrality to avoid detrimental effects on cell viability. For preparing chitosan-enriched fibrin hydrogel, the $\mathrm{pH}$ of the solution after the acidic dissolution of chitosan in deionized water must be increased. Following testing several batches of chitosan with $20 \%, 33 \%$ and $40 \%$ DA, only the solution of chitosan with $40 \%$ DA could be brought to $\mathrm{pH}$ neutrality without forming precipitates [123]. The stock solution of Puramatrix ${ }^{\mathrm{TM}}(1 \% w / v)$ exhibits $\mathrm{pH}$ 3.0, which can adversely affect cell viability. Therefore, it is important to work quickly to minimize the amount of time that cells are in contact with this material prior to the addition of culture medium [329].

\section{Conclusions}

Despite the fact that dentin-pulp tissue regeneration in laboratory conditions provided functional odontoblasts capable of regenerating tubular dentin, the clinical translation of these experiments will require cooperation between biologists, biomaterials scientists and clinicians in order to develop safe and effective approaches to dental pulp regeneration. Among the obstacles to overcome prior to clinical translation is the need for exogenous chemotactic factors that have to be incorporated into the scaffolds for the active recruitment of cells from the periapical region in cell-free tissue-engineering approaches [332], yet the plethora of GFs included and expressed by dentin makes this task very complex. Interestingly, the biological ligand on a scaffold surface is a major factor that controls both cell attachment and spreading. Despite the stated hypothesis that synthetic materials might be better candidates for tissue engineering approaches, given the high control over their properties and being functionalized with specific bioactive motifs, it seems that natural biomaterials, particularly collagen and fibrin, are superior to synthetic materials in dental pulp tissue regeneration. Still, even though hydrogels show great potential in fulfilling the criteria of the ideal scaffold material for dentin-pulp complex regeneration, devising an ideal scaffold material that is injectable, biodegradable, biocompatible, non-immunogenic. characterizied by high porosity and adequate mechanical properties, which is also biomimetic, can act as a 3D matrix to mimic cells' natural habitats. In addition to being easily biofunctionalized and combined with stem/progenitor cells and can support cellular adhesion, migration, proliferation and differentiation, is a task yet to be accomplished.

Author Contributions: Authors: M.M.S.A., A.A.E.-R., K.M.S., S.E.M., I.A.R., D.R., and K.M.F.E.-S.: have contributed in data curation, original draft preparation writing-Review \& Editing; C.E.D.: have contributed by funding acquisition, supervision and review editing. All authors have read and agreed to the published version of the manuscript.

Funding: We acknowledge financial support by Land Schleswig-Holstein within the funding programme Open Access Publikationsfonds.

Conflicts of Interest: The authors declare no conflict of interest.

\section{References}

1. Galler, K.M.; Hartgerink, J.D.; Cavender, A.C.; Schmalz, G.; D'Souza, R.N. A customized self-assembling peptide hydrogel for dental pulp tissue engineering. Tissue Eng. Part A 2012, 18, 176-184. [CrossRef]

2. Galler, K.M.; Aulisa, L.; Regan, K.R.; D'Souza, R.N.; Hartgerink, J.D. Self-Assembling Multidomain Peptide Hydrogels: Designed Susceptibility to Enzymatic Cleavage Allows Enhanced Cell Migration and Spreading. J. Am. Chem. Soc. 2010, 132, 3217-3223. [CrossRef] [PubMed]

3. Kawashima, N.; Okiji, T. Odontoblasts: Specialized hard-tissue-forming cells in the dentin-pulp complex. Congenit. Anom. 2016, 56, 144-153. [CrossRef]

4. Fahmy, S.H.; Hassanien, E.E.S.; Nagy, M.M.; El Batouty, K.M.; Mekhemar, M.; Fawzy El Sayed, K.; Hassanein, E.H.; Wiltfang, J.; Dorfer, C. Investigation of the regenerative potential of necrotic mature teeth following different revascularisation protocols. Aust. Endod. J. 2017, 43, 73-82. [CrossRef] 
5. Fawzy El-Sayed, K.M.; Elsalawy, R.; Ibrahim, N.; Gadalla, M.; Albargasy, H.; Zahra, N.; Mokhtar, S.; El Nahhas, N.; El Kaliouby, Y.; Dorfer, C.E. The Dental Pulp Stem/Progenitor Cells-Mediated Inflammatory-Regenerative Axis. Tissue Eng. Part B Rev. 2019, 25, 445-460. [CrossRef]

6. Fawzy El-Sayed, K.M.; Klingebiel, P.; Dorfer, C.E. Toll-like Receptor Expression Profile of Human Dental Pulp Stem/Progenitor Cells. J. Endod. 2016, 42, 413-417. [CrossRef] [PubMed]

7. Chang, B.; Ahuja, N.; Ma, C.; Liu, X. Injectable scaffolds: Preparation and application in dental and craniofacial regeneration. Mater. Sci. Eng. R Rep. 2017, 111, 1-26. [CrossRef] [PubMed]

8. Chaussain-Miller, C.; Fioretti, F.; Goldberg, M.; Menashi, S. The role of matrix metalloproteinases (MMPs) in human caries. J. Dent. Res. 2006, 85, 22-32. [CrossRef] [PubMed]

9. Goldberg, M.; Smith, A. Cells and extracellular matrices of dentin and pulp: A biological basis for repair and tissue engineering. Crit. Rev. Oral. Biol. Med. 2004, 15, 13-27. [CrossRef] [PubMed]

10. Shi, S.; Gronthos, S. Perivascular niche of postnatal mesenchymal stem cells in human bone marrow and dental pulp. JBMR 2003, 18, 696-704. [CrossRef]

11. Sharma, L.A.; Love, R.M. Scaffolds for regeneration of the pulp-dentine complex. In Handbook of Tissue Engineering Scaffolds: Volume One; Elsevier: Amsterdam, The Netherlands, 2019; pp. 459-478.

12. Jernvall, J.; Thesleff, I. Reiterative signaling and patterning during mammalian tooth morphogenesis. Mech. Dev. 2000, 92, 19-29. [CrossRef]

13. Smith, A.; Lumley, P.; Tomson, P.; Cooper, P. Dental regeneration and materials-A partnership. Clin. Oral Investig. 2008, 12, 103-108. [CrossRef] [PubMed]

14. Cooper, P.R.; Takahashi, Y.; Graham, L.W.; Simon, S.; Imazato, S.; Smith, A.J. Inflammation-regeneration interplay in the dentine-pulp complex. J. Dent. 2010, 38, 687-697. [CrossRef] [PubMed]

15. Fawzy El-Sayed, K.M.; Ahmed, G.M.; Abouauf, E.A.; Schwendicke, F. Stem/progenitor cell-mediated pulpal tissue regeneration: A systematic review and meta-analysis. Int. Endod. J. 2019, 52, 1573-1585. [CrossRef]

16. Fawzy El-Sayed, K.M.; Jakusz, K.; Jochens, A.; Dorfer, C.; Schwendicke, F. Stem Cell Transplantation for Pulpal Regeneration: A Systematic Review. Tissue Eng. Part B Rev. 2015, 21, 451-460. [CrossRef]

17. Ahmed, G.M.; Abouauf, E.A.; AbuBakr, N.; Dorfer, C.E.; El-Sayed, K.F. Tissue Engineering Approaches for Enamel, Dentin, and Pulp Regeneration: An Update. Stem Cells Int. 2020, 2020, 5734539. [CrossRef]

18. Lovelace, T.W.; Henry, M.A.; Hargreaves, K.M.; Diogenes, A. Evaluation of the delivery of mesenchymal stem cells into the root canal space of necrotic immature teeth after clinical regenerative endodontic procedure. J. Endod. 2011, 37, 133-138. [CrossRef]

19. Yang, J.; Yuan, G.; Chen, Z. Pulp regeneration: Current approaches and future challenges. Front. Physiol. 2016, 7, 58. [CrossRef]

20. Galler, K.M.; D’Souza, R.N.; Federlin, M.; Cavender, A.C.; Hartgerink, J.D.; Hecker, S.; Schmalz, G. Dentin conditioning codetermines cell fate in regenerative endodontics. J. Endod. 2011, 37, 1536-1541. [CrossRef]

21. Trevino, E.G.; Patwardhan, A.N.; Henry, M.A.; Perry, G.; Dybdal-Hargreaves, N.; Hargreaves, K.M.; Diogenes, A. Effect of irrigants on the survival of human stem cells of the apical papilla in a platelet-rich plasma scaffold in human root tips. J. Endod. 2011, 37, 1109-1115. [CrossRef]

22. Galler, K.M.; Eidt, A.; Schmalz, G. Cell-free approaches for dental pulp tissue engineering. J. Endod. 2014, 40, S41-S45. [CrossRef] [PubMed]

23. Bakhtiar, H.; Mazidi, A.; Mohammadi Asl, S.; Ellini, M.R.; Moshiri, A.; Nekoofar, M.H.; Dummer, P.M.H. The role of stem cell therapy in regeneration of dentine-pulp complex: A systematic review. Prog. Biomater. 2018, 7, 249-268. [CrossRef]

24. Mullane, E.M.; Dong, Z.; Sedgley, C.M.; Hu, J.C.C.; Botero, T.M.; Holland, G.R.; Nör, J.E. Effects of VEGF and FGF2 on the revascularization of severved human dental pulps. J. Dent. Res. 2008, 87, 1144-1148. [CrossRef]

25. Nakashima, M.; Reddi, A.H. The application of bone morphogenetic proteins to dental tissue engineering. Nat. Biotechnol. 2003, 21, 1025-1032. [CrossRef]

26. Galler, K.M.; D'Souza, R.N.; Hartgerink, J.D. Biomaterials and their potential applications for dental tissue engineering. J. Mater. Chem. 2010, 20, 8730-8746. [CrossRef]

27. Fan, C.; Wang, D.-A. Macroporous hydrogel scaffolds for three-dimensional cell culture and tissue engineering. Tissue Eng. Part B Rev. 2017, 23, 451-461. [CrossRef] [PubMed]

28. Mantha, S.; Pillai, S.; Khayambashi, P.; Upadhyay, A.; Zhang, Y.; Tao, O.; Pham, H.M.; Tran, S.D. Smart Hydrogels in Tissue Engineering and Regenerative Medicine. Materials 2019, 12, 3323. [CrossRef] [PubMed] 
29. Yang, J.M.; Olanrele, O.S.; Zhang, X.; Hsu, C.C. Fabrication of Hydrogel Materials for Biomedical Applications. In Novel Biomaterials for Regenerative Medicine; Chun, H.J., Park, K., Kim, C.-H., Khang, G., Eds.; Springer: Singapore, 2018; pp. 197-224. [CrossRef]

30. Ahmed, E.M. Hydrogel: Preparation, characterization, and applications: A review. J. Adv. Res. 2015, 6, 105-121. [CrossRef]

31. Varaprasad, K.; Raghavendra, G.M.; Jayaramudu, T.; Yallapu, M.M.; Sadiku, R. A mini review on hydrogels classification and recent developments in miscellaneous applications. Mater. Sci. Eng. C 2017, 79, 958-971. [CrossRef]

32. Nguyen, M.K.; Lee, D.S. Injectable Biodegradable Hydrogels. Macromol. Biosci. 2010, 10, 563-579. [CrossRef]

33. Kharkar, P.M.; Kiick, K.L.; Kloxin, A.M. Designing degradable hydrogels for orthogonal control of cell microenvironments. Chem. Soc. Rev. 2013, 42, 7335-7372. [CrossRef] [PubMed]

34. Maitra, J.; Shukla, V.K. Cross-linking in hydrogels-a review. Am. J. Polym. Sci. 2014, 4, $25-31$.

35. Wong Po Foo, C.T.S.; Lee, J.S.; Mulyasasmita, W.; Parisi-Amon, A.; Heilshorn, S.C. Two-component protein-engineered physical hydrogels for cell encapsulation. Proc. Natl. Acad. Sci. USA 2009, 106, 22067-22072. [CrossRef] [PubMed]

36. Raddall, G.; Mello, I.; Leung, B.M. Biomaterials and scaffold design strategies for regenerative endodontic therapy. Front. Bioeng. Biotechnol. 2019, 7, 317. [CrossRef]

37. Yuan, Z.; Nie, H.; Wang, S.; Lee, C.H.; Li, A.; Fu, S.Y.; Zhou, H.; Chen, L.; Mao, J.J. Biomaterial selection for tooth regeneration. Tissue Eng. Part B Rev. 2011, 17, 373-388. [CrossRef]

38. Partap, S. Scaffolds \& Surfaces. In Basic Engineering for Medics and Biologists: An ESEM Primer; Lee, T.C., Niederer, P., Eds.; IOS Press: Amsterdam, The Netherlands, 2010; Volume 152, pp. 187-201.

39. Temenoff, J.S.; Mikos, A.G. Injectable biodegradable materials for orthopedic tissue engineering. Biomaterials 2000, 21, 2405-2412. [CrossRef]

40. Vermonden, T.; Censi, R.; Hennink, W.E. Hydrogels for protein delivery. Chem. Rev. 2012, 112, $2853-2888$. [CrossRef]

41. Lai, J.-Y. Biocompatibility of chemically cross-linked gelatin hydrogels for ophthalmic use. J. Mater. Sci. Mater. Med. 2010, 21, 1899-1911. [CrossRef]

42. Babensee, J.E.; Anderson, J.M.; McIntire, L.V.; Mikos, A.G. Host response to tissue engineered devices. Adv. Drug Del. Rev. 1998, 33, 111-139. [CrossRef]

43. Zhu, J. Bioactive modification of poly (ethylene glycol) hydrogels for tissue engineering. Biomaterials 2010, 31, 4639-4656. [CrossRef]

44. Hennink, W.E.; van Nostrum, C.F. Novel crosslinking methods to design hydrogels. Adv. Drug Del. Rev. 2012, 64, 223-236. [CrossRef]

45. Lutolf, M.; Hubbell, J. Synthesis and physicochemical characterization of end-linked poly (ethylene glycol)-co-peptide hydrogels formed by Michael-type addition. Biomacromolecules 2003, 4, 713-722. [CrossRef] [PubMed]

46. Zisch, A.H.; Lutolf, M.P.; Ehrbar, M.; Raeber, G.P.; Rizzi, S.C.; Davies, N.; Schmökel, H.; Bezuidenhout, D.; Djonov, V.; Zilla, P. Cell-demanded release of VEGF from synthetic, biointeractive cell-ingrowth matrices for vascularized tissue growth. FASEB J. 2003, 17, 2260-2262. [CrossRef] [PubMed]

47. O’brien, F.J. Biomaterials \& scaffolds for tissue engineering. Mater. Today. 2011, 14, 88-95.

48. Lai, J.-Y.; Li, Y.-T. Functional Assessment of Cross-Linked Porous Gelatin Hydrogels for Bioengineered Cell Sheet Carriers. Biomacromolecules 2010, 11, 1387-1397. [CrossRef]

49. Hou, Q.; Paul, A.; Shakesheff, K.M. Injectable scaffolds for tissue regeneration. J. Mater. Chem. 2004, 14, 1915-1923. [CrossRef]

50. Shung, A.K.; Behravesh, E.; Jo, S.; Mikos, A.G. Crosslinking characteristics of and cell adhesion to an injectable poly (propylene fumarate-co-ethylene glycol) hydrogel using a water-soluble crosslinking system. Tissue Eng. 2003, 9, 243-254. [CrossRef]

51. Kempen, D.H.; Lu, L.; Kim, C.; Zhu, X.; Dhert, W.J.; Currier, B.L.; Yaszemski, M.J. Controlled drug release from a novel injectable biodegradable microsphere/scaffold composite based on poly (propylene fumarate). J. Biomed. Mater. Res. A 2006, 77, 103-111. [CrossRef]

52. He, S.; Yaszemski, M.J.; Yasko, A.W.; Engel, P.S.; Mikos, A.G. Injectable biodegradable polymer composites based on poly (propylene fumarate) crosslinked with poly (ethylene glycol)-dimethacrylate. Biomaterials 2000, 21, 2389-2394. [CrossRef] 
53. Dissanayaka, W.L.; Zhang, C. Dental Pulp Stem Cells and Hydrogel in Pulp Regeneration. In Dental Stem Cells: Regenerative Potential; Springer: Berlin/Heidelberg, Germany, 2016; pp. 133-145.

54. Ajay Sharma, L.; Sharma, A.; Dias, G.J. Advances in regeneration of dental pulp-A literature review. J. Investig. Clin. Dent. 2015, 6, 85-98. [CrossRef]

55. Ma, P.X. Biomimetic materials for tissue engineering. Adv. Drug Del. Rev. 2008, 60, 184-198. [CrossRef] [PubMed]

56. Zhang, R.; Xie, L.; Wu, H.; Yang, T.; Zhang, Q.; Tian, Y.; Liu, Y.; Han, X.; Guo, W.; He, M. Alginate/laponite hydrogel microspheres co-encapsulating dental pulp stem cells and VEGF for endodontic regeneration. Acta Biomater. 2020, 113, 305-316. [CrossRef] [PubMed]

57. Zein, N.; Harmouch, E.; Lutz, J.-C.; Fernandez De Grado, G.; Kuchler-Bopp, S.; Clauss, F.; Offner, D.; Hua, G.; Benkirane-Jessel, N.; Fioretti, F. Polymer-Based Instructive Scaffolds for Endodontic Regeneration. Materials 2019, 12, 2347. [CrossRef] [PubMed]

58. Chou, S.-F.; Luo, L.-J.; Lai, J.-Y. Gallic acid grafting effect on delivery performance and antiglaucoma efficacy of antioxidant-functionalized intracameral pilocarpine carriers. Acta Biomater. 2016, 38, 116-128. [CrossRef] [PubMed]

59. Drury, J.L.; Mooney, D.J. Hydrogels for tissue engineering: Scaffold design variables and applications. Biomaterials 2003, 24, 4337-4351. [CrossRef]

60. Kwon, Y.S.; Lee, S.H.; Hwang, Y.C.; Rosa, V.; Lee, K.W.; Min, K.S. Behaviour of human dental pulp cells cultured in a collagen hydrogel scaffold cross-linked with cinnamaldehyde. Int. Endod. J. 2017, 50, 58-66. [CrossRef]

61. Pankajakshan, D.; Voytik-Harbin, S.L.; Nor, J.E.; Bottino, M.C. Injectable Highly Tunable Oligomeric Collagen Matrices for Dental Tissue Regeneration. ACS Appl. Bio Mater. 2020, 3, 859-868. [CrossRef]

62. Bhatnagar, D.; Bherwani, A.K.; Simon, M.; Rafailovich, M.H. Biomineralization on enzymatically cross-linked gelatin hydrogels in the absence of dexamethasone. Dent. Mater. 2015, 3, 5210-5219. [CrossRef]

63. Miyazawa, A.; Matsuno, T.; Asano, K.; Tabata, Y.; Satoh, T. Controlled release of simvastatin from biodegradable hydrogels promotes odontoblastic differentiation. Dent. Mater. J. 2015, 34, 466-474. [CrossRef]

64. Khayat, A.; Monteiro, N.; Smith, E.; Pagni, S.; Zhang, W.; Khademhosseini, A.; Yelick, P.C. GelMA-encapsulated hDPSCs and HUVECs for dental pulp regeneration. J. Dent. Res. 2017, 96, 192-199. [CrossRef]

65. Park, J.H.; Gillispie, G.J.; Copus, J.S.; Zhang, W.; Atala, A.; Yoo, J.J.; Yelick, P.C.; Lee, S.J. The effect of BMP-mimetic peptide tethering bioinks on the differentiation of dental pulp stem cells (DPSCs) in 3D bioprinted dental constructs. Biofabrication 2020, 12, 35029. [CrossRef] [PubMed]

66. Galler, K.M.; Cavender, A.C.; Koeklue, U.; Suggs, L.J.; Schmalz, G.; D’Souza, R.N. Bioengineering of dental stem cells in a PEGylated fibrin gel. Regen. Med. 2011, 6, 191-200. [CrossRef] [PubMed]

67. Jang, J.-H.; Moon, J.-H.; Kim, S.G.; Kim, S.-Y. Pulp regeneration with hemostatic matrices as a scaffold in an immature tooth minipig model. Sci. Rep. 2020, 10, 12536. [CrossRef] [PubMed]

68. Athirasala, A.; Lins, F.; Tahayeri, A.; Hinds, M.; Smith, A.J.; Sedgley, C.; Ferracane, J.; Bertassoni, L.E. A Novel Strategy to Engineer Pre-Vascularized Full-Length Dental Pulp-like Tissue Constructs. Sci. Rep. 2017, 7, 3323. [CrossRef] [PubMed]

69. Ajay Sharma, L.; Ali, M.A.; Love, R.M.; Wilson, M.J.; Dias, G.J. Novel keratin preparation supports growth and differentiation of odontoblast-like cells. Int. Endod. J. 2016, 49, 471-482. [CrossRef]

70. Ajay Sharma, L. Wool-derived keratin hydrogel as a potential scaffold for pulp-dentine regeneration: An in vitro and in vivo study. Ph.D. Thesis, University of Otago, Dunedin, New Zealand, 2016.

71. Zhang, S.; Thiebes, A.L.; Kreimendahl, F.; Ruetten, S.; Buhl, E.M.; Wolf, M.; Jockenhoevel, S.; Apel, C. Extracellular Vesicles-Loaded Fibrin Gel Supports Rapid Neovascularization for Dental Pulp Regeneration. Int. J. Mol. Sci. 2020, 21, 4226. [CrossRef]

72. Ha, M.; Athirasala, A.; Tahayeri, A.; Menezes, P.P.; Bertassoni, L.E. Micropatterned hydrogels and cell alignment enhance the odontogenic potential of stem cells from apical papilla in-vitro. Dent. Mater. 2020, 36, 88-96. [CrossRef]

73. Xiao, M.; Qiu, J.; Kuang, R.; Zhang, B.; Wang, W.; Yu, Q. Synergistic effects of stromal cell-derived factor- $1 \alpha$ and bone morphogenetic protein-2 treatment on odontogenic differentiation of human stem cells from apical papilla cultured in the VitroGel 3D system. Cell Tissue Res. 2019, 378, 207-220. [CrossRef] 
74. Galler, K.M.; Cavender, A.; Yuwono, V.; Dong, H.; Shi, S.; Schmalz, G.; Hartgerink, J.D.; D’Souza, R.N. Self-assembling peptide amphiphile nanofibers as a scaffold for dental stem cells. Tissue Eng. Part A. 2008, 14, 2051-2058. [CrossRef]

75. Colombo, J.S.; Jia, S.; D'Souza, R.N. Modeling Hypoxia Induced Factors to Treat Pulpal Inflammation and Drive Regeneration. J. Endod. 2020, 46, S19-S25. [CrossRef]

76. Rosa, V.; Zhang, Z.; Grande, R.; Nör, J. Dental pulp tissue engineering in full-length human root canals. J. Dent. Res. 2013, 92, 970-975. [CrossRef] [PubMed]

77. Ito, T.; Kaneko, T.; Sueyama, Y.; Kaneko, R.; Okiji, T. Dental pulp tissue engineering of pulpotomized rat molars with bone marrow mesenchymal stem cells. Odontology 2017, 105, 392-397. [CrossRef] [PubMed]

78. Sueyama, Y.; Kaneko, T.; Ito, T.; Kaneko, R.; Okiji, T. Implantation of Endothelial Cells with Mesenchymal Stem Cells Accelerates Dental Pulp Tissue Regeneration/Healing in Pulpotomized Rat Molars. J. Endod. 2017, 43, 943-948. [CrossRef] [PubMed]

79. Gu, B.; Kaneko, T.; Zaw, S.Y.M.; Sone, P.P.; Murano, H.; Sueyama, Y.; Zaw, Z.C.T.; Okiji, T. Macrophage populations show an M1-to-M2 transition in an experimental model of coronal pulp tissue engineering with mesenchymal stem cells. Int. Endod. J. 2018, 52, 504-514. [CrossRef]

80. Kaneko, T.; Sone, P.P.; Zaw, S.Y.M.; Sueyama, Y.; Zaw, Z.C.T.; Okada, Y.; Murano, H.; Gu, B.; Okiji, T. In vivo fate of bone marrow mesenchymal stem cells implanted into rat pulpotomized molars. Stem. Cell Res. 2019, 38, 101457. [CrossRef]

81. Smith, J.G.; Smith, A.J.; Shelton, R.M.; Cooper, P.R. Dental Pulp Cell Behavior in Biomimetic Environments. J. Dent. Res. 2015, 94, 1552-1559. [CrossRef]

82. Bekhouche, M.; Bolon, M.; Charriaud, F.; Lamrayah, M.; Da Costa, D.; Primard, C.; Costantini, A.; Pasdeloup, M.; Gobert, S.; Mallein-Gerin, F. Development of an antibacterial nanocomposite hydrogel for human dental pulp engineering. J. Mater. Chem. B 2020, 8, 8422-8432. [CrossRef]

83. Bhoj, M.; Zhang, C.; Green, D.W. A First Step in De Novo Synthesis of a Living Pulp Tissue Replacement Using Dental Pulp MSCs and Tissue Growth Factors, Encapsulated within a Bioinspired Alginate Hydrogel. J. Endod. 2015, 41, 1100-1107. [CrossRef]

84. Kikuchi, N.; Kitamura, C.; Morotomi, T.; Inuyama, Y.; Ishimatsu, H.; Tabata, Y.; Nishihara, T.; Terashita, M. Formation of dentin-like particles in dentin defects above exposed pulp by controlled release of fibroblast growth factor 2 from gelatin hydrogels. J. Endod. 2007, 33, 1198-1202. [CrossRef]

85. Nagy, M.M.; Tawfik, H.E.; Hashem, A.A.R.; Abu-Seida, A.M. Regenerative potential of immature permanent teeth with necrotic pulps after different regenerative protocols. J. Endod. 2014, 40, 192-198. [CrossRef]

86. Dobie, K.; Smith, G.; Sloan, A.J.; Smith, A.J. Effects of alginate hydrogels and TGF- $\beta 1$ on human dental pulp repair in vitro. Connect. Tissue Res. 2002, 43, 387-390. [CrossRef] [PubMed]

87. Mu, X.; Shi, L.; Pan, S.; He, L.; Niu, Y.; Wang, X. A Customized Self-Assembling Peptide Hydrogel-Wrapped Stem Cell Factor Targeting Pulp Regeneration Rich in Vascular-Like Structures. ACS Omega 2020, 5, 16568-16574. [CrossRef] [PubMed]

88. Nguyen, P.K.; Gao, W.; Patel, S.D.; Siddiqui, Z.; Weiner, S.; Shimizu, E.; Sarkar, B.; Kumar, V.A. Self-assembly of a dentinogenic peptide hydrogel. ACS Omega 2018, 3, 5980-5987. [CrossRef] [PubMed]

89. Xia, K.; Chen, Z.; Chen, J.; Xu, H.; Xu, Y.; Yang, T.; Zhang, Q. RGD-and VEGF-Mimetic Peptide Epitope-Functionalized Self-Assembling Peptide Hydrogels Promote Dentin-Pulp Complex Regeneration. Int. J. Nanomed. 2020, 15, 6631. [CrossRef] [PubMed]

90. Tabata, Y.; Nagano, A.; Ikada, Y. Biodegradation of Hydrogel Carrier Incorporating Fibroblast Growth Factor. Tissue Eng. 1999, 5, 127-138. [CrossRef]

91. Ishihara, M.; Obara, K.; Nakamura, S.; Fujita, M.; Masuoka, K.; Kanatani, Y.; Takase, B.; Hattori, H.; Morimoto, Y.; Ishihara, M. Chitosan hydrogel as a drug delivery carrier to control angiogenesis. J. Artif. Organs 2006, 9, 8-16. [CrossRef]

92. Ferreira, A.M.; Gentile, P.; Chiono, V.; Ciardelli, G. Collagen for bone tissue regeneration. Acta Biomater. 2012, 8, 3191-3200. [CrossRef]

93. DeVolder, R.; Kong, H.-J. Hydrogels for in vivo-like three-dimensional cellular studies. WIREs Syst. Biol. Med. 2012, 4, 351-365. [CrossRef]

94. Bidarra, S.J.; Barrias, C.C.; Granja, P.L. Injectable alginate hydrogels for cell delivery in tissue engineering. Acta Biomater. 2014, 10, 1646-1662. [CrossRef] 
95. Alberts, B.; Johnson, A.; Lewis, J.; Raff, M.; Roberts, K. Molecular Biology of The Cell; Taylor and Francis Group: Abingdon, UK, 2002.

96. Sharma, S.; Srivastava, D.; Grover, S.; Sharma, V. Biomaterials in tooth tissue engineering: A review. J. Clin. Diagn. Res 2014, 8, 309-315. [CrossRef]

97. Reilly, G.C.; Engler, A.J. Intrinsic extracellular matrix properties regulate stem cell differentiation. J. Biomech. 2010, 43, 55-62. [CrossRef]

98. Zoldan, J.; Karagiannis, E.D.; Lee, C.Y.; Anderson, D.G.; Langer, R.; Levenberg, S. The influence of scaffold elasticity on germ layer specification of human embryonic stem cells. Biomaterials 2011, 32, 9612-9621. [CrossRef] [PubMed]

99. Sekar, S.; Sasirekha, K.; Krishnakumar, S.; Sastry, T.P. A novel cross-linked human amniotic membrane for corneal implantations. Proc. Inst. Mech. Eng. Part H J. Eng. Med. 2013, 227, 221-228. [CrossRef] [PubMed]

100. Ma, D.H.-K.; Chen, H.-C.; Ma, K.S.-K.; Lai, J.-Y.; Yang, U.; Yeh, L.-K.; Hsueh, Y.-J.; Chu, W.-K.; Lai, C.-H.; Chen, J.-K. Preservation of human limbal epithelial progenitor cells on carbodiimide cross-linked amniotic membrane via integrin-linked kinase-mediated Wnt activation. Acta Biomater. 2016, 31, 144-155. [CrossRef] [PubMed]

101. Whittington, C.F.; Yoder, M.C.; Voytik-Harbin, S.L. Collagen-polymer guidance of vessel network formation and stabilization by endothelial colony forming cells in vitro. Macromol. Biosci. 2013, 13, 1135-1149. [CrossRef]

102. Veis, A.; Goldberg, M. Pulp Extracellular Matrix; Springer: Berlin/Heidelberg, Germany, 2014; pp. $35-46$.

103. Smith, A.J.; Scheven, B.A.; Takahashi, Y.; Ferracane, J.L.; Shelton, R.M.; Cooper, P.R. Dentine as a bioactive extracellular matrix. Arch. Oral Biol. 2012, 57, 109-121. [CrossRef] [PubMed]

104. Souron, J.B.; Petiet, A.; Decup, F.; Tran, X.V.; Lesieur, J.; Poliard, A.; Le Guludec, D.; Letourneur, D.; Chaussain, C.; Rouzet, F.; et al. Pulp cell tracking by radionuclide imaging for dental tissue engineering. Tissue Eng. Part C Methods 2014, 20, 188-197. [CrossRef]

105. Gasperini, L.; Mano, J.F.; Reis, R.L. Natural polymers for the microencapsulation of cells. J. R. Soc. Interface 2014, 11, 20140817. [CrossRef]

106. Lai, J.-Y.; Lin, P.-K.; Hsiue, G.-H.; Cheng, H.-Y.; Huang, S.-J.; Li, Y.-T. Low Bloom Strength Gelatin as a Carrier for Potential Use in Retinal Sheet Encapsulation and Transplantation. Biomacromolecules 2009, 10, 310-319. [CrossRef]

107. Pierce, B.F.; Pittermann, E.; Ma, N.; Gebauer, T.; Neffe, A.T.; Hölscher, M.; Jung, F.; Lendlein, A. Viability of human mesenchymal stem cells seeded on crosslinked entropy-elastic gelatin-based hydrogels. Macromol. Biosci. 2012, 12, 312-321. [CrossRef]

108. Qu, T.; Liu, X. Nano-structured gelatin/bioactive glass hybrid scaffolds for the enhancement of odontogenic differentiation of human dental pulp stem cells. J. Mater. Chem. B 2013, 1, 4764-4772. [CrossRef] [PubMed]

109. Weng, Y.J.; Ren, J.R.; Huang, N.; Wang, J.; Chen, J.Y.; Leng, Y.X.; Liu, H.Q. Surface engineering of Ti-O films by photochemical immobilization of gelatin. Mater. Sci. Eng. C 2008, 28, 1495-1500. [CrossRef]

110. Van den Steen, P.E.; Dubois, B.; Nelissen, I.; Rudd, P.M.; Dwek, R.A.; Opdenakker, G. Biochemistry and molecular biology of gelatinase B or matrix metalloproteinase-9 (MMP-9). Crit. Rev. Biochem. Mol. Biol. 2002, 37, 375-536. [CrossRef] [PubMed]

111. Zhu, Y.; Gao, C.; He, T.; Shen, J. Endothelium regeneration on luminal surface of polyurethane vascular scaffold modified with diamine and covalently grafted with gelatin. Biomaterials 2004, 25, 423-430. [CrossRef]

112. Salamon, A.; van Vlierberghe, S.; van Nieuwenhove, I.; Baudisch, F.; Graulus, G.-J.; Benecke, V.; Alberti, K.; Neumann, H.-G.; Rychly, J.; Martins, J.C.; et al. Gelatin-Based Hydrogels Promote Chondrogenic Differentiation of Human Adipose Tissue-Derived Mesenchymal Stem Cells In Vitro. Materials 2014, 7, 1342-1359. [CrossRef]

113. Su, K.; Wang, C. Recent advances in the use of gelatin in biomedical research. Biotechnol. Lett. 2015, 37, 2139-2145. [CrossRef]

114. Radhakrishnan, J.; Krishnan, U.M.; Sethuraman, S. Hydrogel based injectable scaffolds for cardiac tissue regeneration. Biotechnol. Adv. 2014, 32, 449-461. [CrossRef]

115. Zhou, D.; Ito, Y. Inorganic material surfaces made bioactive by immobilizing growth factors for hard tissue engineering. RSC Adv. 2013, 3, 11095-11106. [CrossRef]

116. Sun, M.; Sun, X.; Wang, Z.; Guo, S.; Yu, G.; Yang, H. Synthesis and Properties of Gelatin Methacryloyl (GelMA) Hydrogels and Their Recent Applications in Load-Bearing Tissue. Polymers 2018, 10, 1290. [CrossRef] 
117. Ishimatsu, H.; Kitamura, C.; Morotomi, T.; Tabata, Y.; Nishihara, T.; Chen, K.-K.; Terashita, M. Formation of dentinal bridge on surface of regenerated dental pulp in dentin defects by controlled release of fibroblast growth factor-2 from gelatin hydrogels. J. Endod. 2009, 35, 858-865. [CrossRef]

118. Xiao, S.; Zhao, T.; Wang, J.; Wang, C.; Du, J.; Ying, L.; Lin, J.; Zhang, C.; Hu, W.; Wang, L.; et al. Gelatin Methacrylate(GelMA)-Based Hydrogels for Cell Transplantation: An Effective Strategy for Tissue Engineering. Stem. Cell Rev. 2019, 15, 664-679. [CrossRef] [PubMed]

119. Yue, K.; Trujillo-de Santiago, G.; Alvarez, M.M.; Tamayol, A.; Annabi, N.; Khademhosseini, A. Synthesis, properties, and biomedical applications of gelatin methacryloyl (GelMA) hydrogels. Biomaterials 2015, 73, 254-271. [CrossRef] [PubMed]

120. Nichol, J.W.; Koshy, S.T.; Bae, H.; Hwang, C.M.; Yamanlar, S.; Khademhosseini, A. Cell-laden microengineered gelatin methacrylate hydrogels. Biomaterials 2010, 31, 5536-5544. [CrossRef] [PubMed]

121. Van Den Bulcke, A.I.; Bogdanov, B.; De Rooze, N.; Schacht, E.H.; Cornelissen, M.; Berghmans, H. Structural and rheological properties of methacrylamide modified gelatin hydrogels. Biomacromolecules 2000, 1, 31-38. [CrossRef] [PubMed]

122. Monteiro, N.; Thrivikraman, G.; Athirasala, A.; Tahayeri, A.; França, C.M.; Ferracane, J.L.; Bertassoni, L.E. Photopolymerization of cell-laden gelatin methacryloyl hydrogels using a dental curing light for regenerative dentistry. Dent. Mater. 2018, 34, 389-399. [CrossRef]

123. Ducret, M.; Montembault, A.; Josse, J.; Pasdeloup, M.; Celle, A.; Benchrih, R.; Mallein-Gerin, F.; Alliot-Licht, B.; David, L.; Farges, J.C. Design and characterization of a chitosan-enriched fibrin hydrogel for human dental pulp regeneration. Dent. Mater. 2019, 35, 523-533. [CrossRef]

124. Roura, S.; Gálvez-Montón, C.; Bayes-Genis, A. Fibrin, the preferred scaffold for cell transplantation after myocardial infarction? An old molecule with a new life. J. Tissue Eng. Regen. Med. 2017, 11, 2304-2313. [CrossRef]

125. Li, Y.; Meng, H.; Liu, Y.; Lee, B.P. Fibrin Gel as an Injectable Biodegradable Scaffold and Cell Carrier for Tissue Engineering. Sci. World J. 2015, 2015, 685690. [CrossRef]

126. Brown, A.C.; Barker, T.H. Fibrin-based biomaterials: Modulation of macroscopic properties through rational design at the molecular level. Acta Biomater. 2014, 10, 1502-1514. [CrossRef]

127. Verma, P.; Nosrat, A.; Kim, J.R.; Price, J.B.; Wang, P.; Bair, E.; Xu, H.H.; Fouad, A.F. Effect of Residual Bacteria on the Outcome of Pulp Regeneration In Vivo. J. Dent. Res. 2017, 96, 100-106. [CrossRef]

128. Shenoi, P.R.; Morey, E.S.; Makade, C.S.; Gunwal, M.K.; Khode, R.T.; Wanmali, S.S. In vitro evaluation of the antimicrobial efficacy of chitosan and other endodontic irrigants against Enterococcus faecalis. Gen. Dent. 2016, 64, 60-63. [PubMed]

129. Shrestha, A.; Kishen, A. Antibacterial Nanoparticles in Endodontics: A Review. J. Endod. 2016, 42, 1417-1426. [CrossRef] [PubMed]

130. Alghamdi, F.; Shakir, M. The Influence of Enterococcus faecalis as a Dental Root Canal Pathogen on Endodontic Treatment: A Systematic Review. Cureus 2020, 12, e7257. [CrossRef] [PubMed]

131. Renard, E.; Amiaud, J.; Delbos, L.; Charrier, C.; Montembault, A.; Ducret, M.; Farges, F.; David, L.; Alliot-Licht, B.; Gaudin, A. Dental pulp inflammatory/immune response to a chitosan-enriched fibrin hydrogel in the pulpotomised rat incisor. Eur. Cells Mater. 2020, 40, 74-87. [CrossRef]

132. Forier, K.; Raemdonck, K.; De Smedt, S.C.; Demeester, J.; Coenye, T.; Braeckmans, K. Lipid and polymer nanoparticles for drug delivery to bacterial biofilms. J. Control. Release 2014, 190, 607-623. [CrossRef]

133. Wang, L.; Hu, C.; Shao, L. The antimicrobial activity of nanoparticles: Present situation and prospects for the future. Int. J. Nanomed. 2017, 12, 1227-1249. [CrossRef]

134. El Moshy, S.; Radwan, I.A.; Rady, D.; Abbass, M.M.S.; El-Rashidy, A.A.; Sadek, K.M.; Dorfer, C.E.; Fawzy El-Sayed, K.M. Dental Stem Cell-Derived Secretome/Conditioned Medium: The Future for Regenerative Therapeutic Applications. Stem Cells Int. 2020, 2020, 7593402. [CrossRef]

135. Théry, C.; Witwer, K.W.; Aikawa, E.; Alcaraz, M.J.; Anderson, J.D.; Andriantsitohaina, R.; Antoniou, A.; Arab, T.; Archer, F.; Atkin-Smith, G.K.; et al. Minimal information for studies of extracellular vesicles 2018 (MISEV2018): A position statement of the International Society for Extracellular Vesicles and update of the MISEV2014 guidelines. J. Extracell. Vesicles 2018, 7. [CrossRef]

136. Kleinman, H.K.; Martin, G.R. Matrigel: Basement membrane matrix with biological activity. Semin. Cancer Biol. 2005, 15, 378-386. [CrossRef] 
137. Shaw, L.M. Tumor cell invasion assays In Cell Migration: Developmental Methods and Protocols; Guan, J.-L., Ed.; Springer Science \& Business Media: Berlin, Germany, 2005; Volume 294, pp. 97-105.

138. Hughes, C.S.; Postovit, L.M.; Lajoie, G.A. Matrigel: A complex protein mixture required for optimal growth of cell culture. Proteomics 2010, 10, 1886-1890. [CrossRef]

139. Vukicevic, S.; Kleinman, H.K.; Luyten, F.P.; Roberts, A.B.; Roche, N.S.; Reddi, A.H. Identification of multiple active growth factors in basement membrane Matrigel suggests caution in interpretation of cellular activity related to extracellular matrix components. Exp. Cell Res. 1992, 202, 1-8. [CrossRef]

140. Taub, M.; Wang, Y.; Szczesny, T.M.; Kleinman, H.K. Epidermal growth factor or transforming growth factor alpha is required for kidney tubulogenesis in matrigel cultures in serum-free medium. Proc. Natl. Acad. Sci. USA 1990, 87, 4002-4006. [CrossRef] [PubMed]

141. Lambricht, L.; De Berdt, P.; Vanacker, J.; Leprince, J.; Diogenes, A.; Goldansaz, H.; Bouzin, C.; Préat, V.; Dupont-Gillain, C.; Des Rieux, A. The type and composition of alginate and hyaluronic-based hydrogels influence the viability of stem cells of the apical papilla. Dent. Mater. 2014, 30, e349-e361. [CrossRef] [PubMed]

142. Zhu, L.; Dissanayaka, W.L.; Zhang, C. Dental pulp stem cells overexpressing stromal-derived factor- $1 \alpha$ and vascular endothelial growth factor in dental pulp regeneration. Clin. Oral Investig. 2019, 23, 2497-2509. [CrossRef] [PubMed]

143. Mathieu, S.; Jeanneau, C.; Sheibat-Othman, N.; Kalaji, N.; Fessi, H.; About, I. Usefulness of controlled release of growth factors in investigating the early events of dentin-pulp regeneration. J. Endod. 2013, 39, 228-235. [CrossRef]

144. Coulombe, P.A.; Bousquet, O.; Ma, L.; Yamada, S.; Wirtz, D. The 'ins' and 'outs' of intermediate filament organization. Trends Cell Biol. 2000, 10, 420-428. [CrossRef]

145. Rouse, J.G.; Van Dyke, M.E. A Review of Keratin-Based Biomaterials for Biomedical Applications. Materials 2010, 3, 999-1014. [CrossRef]

146. Hearle, J.W. A critical review of the structural mechanics of wool and hair fibres. Int. J. Biol. Macromol. 2000, 27, 123-138. [CrossRef]

147. Donato, R.K.; Mija, A. Keratin Associations with Synthetic, Biosynthetic and Natural Polymers: An Extensive Review. Polymers 2019, 12, 32. [CrossRef]

148. Hill, P.; Brantley, H.; Van Dyke, M. Some properties of keratin biomaterials: Kerateines. Biomaterials 2010, 31, 585-593. [CrossRef]

149. Ikkai, F.; Naito, S. Dynamic Light Scattering and Circular Dichroism Studies on Heat-Induced Gelation of Hard-Keratin Protein Aqueous Solutions. Biomacromolecules 2002, 3, 482-487. [CrossRef] [PubMed]

150. Ajay Sharma, L.; Love, R.M.; Ali, M.A.; Sharma, A.; Macari, S.; Avadhani, A.; Dias, G.J. Healing response of rat pulp treated with an injectable keratin hydrogel. J. Appl. Biomater. Funct 2017, 15, e244-e250. [CrossRef] [PubMed]

151. Verma, V.; Verma, P.; Ray, P.; Ray, A.R. Preparation of scaffolds from human hair proteins for tissue-engineering applications. Biomed. Mater. 2008, 3, 25007. [CrossRef] [PubMed]

152. Magin, T.M.; Vijayaraj, P.; Leube, R.E. Structural and regulatory functions of keratins. Exp. Cell Res. 2007, 313, 2021-2032. [CrossRef] [PubMed]

153. Izawa, I.; Inagaki, M. Regulatory mechanisms and functions of intermediate filaments: A study using siteand phosphorylation state-specific antibodies. Cancer Sci. 2006, 97, 167-174. [CrossRef]

154. Salas, P.J.; Forteza, R.; Mashukova, A. Multiple roles for keratin intermediate filaments in the regulation of epithelial barrier function and apico-basal polarity. Tissue Barriers 2016, 4, e1178368. [CrossRef]

155. Kumar, V.; Bouameur, J.-E.; Bär, J.; Rice, R.H.; Hornig-Do, H.-T.; Roop, D.R.; Schwarz, N.; Brodesser, S.; Thiering, S.; Leube, R.E.; et al. A keratin scaffold regulates epidermal barrier formation, mitochondrial lipid composition, and activity. J. Cell Biol. 2015, 211, 1057-1075. [CrossRef]

156. Lin, C.-W.; Chen, Y.-K.; Tang, K.-C.; Yang, K.-C.; Cheng, N.-C.; Yu, J. Keratin scaffolds with human adipose stem cells: Physical and biological effects toward wound healing. J. Tissue Eng. Regen. Med. 2019, 13, 1044-1058. [CrossRef]

157. Hesse, M.; Zimek, A.; Weber, K.; Magin, T.M. Comprehensive analysis of keratin gene clusters in humans and rodents. Eur. J. Cell Biol. 2004, 83, 19-26. [CrossRef]

158. Lee, H.; Noh, K.; Lee, S.C.; Kwon, I.-K.; Han, D.-W.; Lee, I.-S.; Hwang, Y.-S. Human hair keratin and its-based biomaterials for biomedical applications. J. Tissue Eng. Regen. Med. 2014, 11, 255-265. [CrossRef] 
159. Augst, A.D.; Kong, H.J.; Mooney, D.J. Alginate Hydrogels as Biomaterials. Macromol. Biosci. 2006, 6, 623-633. [CrossRef] [PubMed]

160. Lee, K.Y.; Mooney, D.J. Alginate: Properties and biomedical applications. Prog. Polym. Sci. 2012, 37, $106-126$. [CrossRef] [PubMed]

161. Bouhadir, K.H.; Lee, K.Y.; Alsberg, E.; Damm, K.L.; Anderson, K.W.; Mooney, D.J. Degradation of partially oxidized alginate and its potential application for tissue engineering. Biotechnol. Prog. 2001, 17, 945-950. [CrossRef] [PubMed]

162. Kuo, C.K.; Ma, P.X. Ionically crosslinked alginate hydrogels as scaffolds for tissue engineering: Part 1. Structure, gelation rate and mechanical properties. Biomaterials 2001, 22, 511-521. [CrossRef]

163. Melin, M.; Joffre-Romeas, A.; Farges, J.C.; Couble, M.L.; Magloire, H.; Bleicher, F. Effects of TGFbeta1 on dental pulp cells in cultured human tooth slices. J. Dent. Res. 2000, 79, 1689-1696. [CrossRef]

164. He, H.; Yu, J.; Liu, Y.; Lu, S.; Liu, H.; Shi, J.; Jin, Y. Effects of FGF2 and TGFbeta1 on the differentiation of human dental pulp stem cells in vitro. Cell Biol. Int. 2008, 32, 827-834. [CrossRef]

165. Hersel, U.; Dahmen, C.; Kessler, H. RGD modified polymers: Biomaterials for stimulated cell adhesion and beyond. Biomaterials 2003, 24, 4385-4415. [CrossRef]

166. Dissanayaka, W.L.; Zhan, X.; Zhang, C.; Hargreaves, K.M.; Jin, L.; Tong, E.H.Y. Coculture of dental pulp stem cells with endothelial cells enhances osteo-/odontogenic and angiogenic potential in vitro. J. Endod. 2012, 38, 454-463. [CrossRef]

167. Fouad, A.F. The Microbial Challenge to Pulp Regeneration. Adv. Dent. Res. 2011, 23, 285-289. [CrossRef]

168. Athirasala, A.; Tahayeri, A.; Thrivikraman, G.; Franca, C.M.; Monteiro, N.; Tran, V.; Ferracane, J.; Bertassoni, L.E. A dentin-derived hydrogel bioink for 3D bioprinting of cell laden scaffolds for regenerative dentistry. Biofabrication 2018, 10, 024101. [CrossRef]

169. Yu, H.; Zhang, X.; Song, W.; Pan, T.; Wang, H.; Ning, T.; Wei, Q.; Xu, H.H.K.; Wu, B.; Ma, D. Effects of 3-dimensional Bioprinting Alginate/Gelatin Hydrogel Scaffold Extract on Proliferation and Differentiation of Human Dental Pulp Stem Cells. J. Endod. 2019, 45, 706-715. [CrossRef] [PubMed]

170. Paulino, A.T.; Simionato, J.I.; Garcia, J.C.; Nozaki, J. Characterization of chitosan and chitin produced from silkworm crysalides. J. Carbohydr. Polym. 2006, 64, 98-103. [CrossRef]

171. Simionato, J.I.; Paulino, A.T.; Garcia, J.C.; Nozaki, J. Adsorption of aluminium from wastewater by chitin and chitosan produced from silkworm chrysalides. Polym. Int. 2006, 55, 1243-1248. [CrossRef]

172. Miranda, D.G.; Malmonge, S.M.; Campos, D.M.; Attik, N.G.; Grosgogeat, B.; Gritsch, K. A chitosan-hyaluronic acid hydrogel scaffold for periodontal tissue engineering. J. Biomed. Mater. Res. B Appl. Biomater. 2016, 104, 1691-1702. [CrossRef] [PubMed]

173. Zhang, X.; Yang, D.; Nie, J. Chitosan/polyethylene glycol diacrylate films as potential wound dressing material. Int. J. Biol. Macromol. 2008, 43, 456-462. [CrossRef] [PubMed]

174. Neamnark, A.; Sanchavanakit, N.; Pavasant, P.; Rujiravanit, R.; Supaphol, P. In vitro biocompatibility of electrospun hexanoyl chitosan fibrous scaffolds towards human keratinocytes and fibroblasts. Eur. Polym. J. 2008, 44, 2060-2067. [CrossRef]

175. Zhao, Q.S.; Ji, Q.X.; Xing, K.; Li, X.Y.; Liu, C.S.; Chen, X.G. Preparation and characteristics of novel porous hydrogel films based on chitosan and glycerophosphate. Carbohydr. Polym. 2009, 76, 410-416. [CrossRef]

176. Lai, J.-Y.; Li, Y.-T.; Wang, T.-P. In vitro response of retinal pigment epithelial cells exposed to chitosan materials prepared with different cross-linkers. Int. J. Mol. Sci. 2010, 11, 5256-5272. [CrossRef]

177. Ahmadi, F.; Oveisi, Z.; Samani, S.M.; Amoozgar, Z. Chitosan based hydrogels: Characteristics and pharmaceutical applications. Res. Pharm. Sci. 2015, 10, 1.

178. Mourya, V.; Inamdar, N.N. Chitosan-modifications and applications: Opportunities galore. React. Funct. Polym. 2008, 68, 1013-1051. [CrossRef]

179. Park, S.-J.; Li, Z.; Hwang, I.-N.; Huh, K.M.; Min, K.-S. Glycol chitin-based thermoresponsive hydrogel scaffold supplemented with enamel matrix derivative promotes odontogenic differentiation of human dental pulp cells. J. Endod. 2013, 39, 1001-1007. [CrossRef] [PubMed]

180. Wu, S.; Zhou, Y.; Yu, Y.; Zhou, X.; Du, W.; Wan, M.; Fan, Y.; Zhou, X.; Xu, X.; Zheng, L. Evaluation of Chitosan Hydrogel for Sustained Delivery of VEGF for Odontogenic Differentiation of Dental Pulp Stem Cells. Stem Cells Int. 2019, 2019. [CrossRef] [PubMed]

181. Zhu, N.; Chatzistavrou, X.; Ge, L.; Qin, M.; Papagerakis, P.; Wang, Y. Biological properties of modified bioactive glass on dental pulp cells. J. Dent. 2019, 83, 18-26. 
182. El Ashiry, E.A.; Alamoudi, N.M.; El Ashiry, M.K.; Bastawy, H.A.; El Derwi, D.A.; Atta, H.M. Tissue engineering of necrotic dental pulp of immature teeth with apical periodontitis in dogs: Radiographic and histological evaluation. J. Clin. Pediatr. Dent. 2018, 42, 373-382. [CrossRef] [PubMed]

183. Garg, H.G.; Hales, C.A. Chemistry and Biology of Hyaluronan; Elsevier: Amsterdam, The Netherlands, 2004.

184. Rice, K.G. The Chemistry, Biology, and Medical Applications of Hyaluronan and Its Derivatives; Laurent, T., Ed.; ACS Publications; Portland Press: London, UK, 1998.

185. Turley, E.A.; Noble, P.W.; Bourguignon, L.Y. Signaling properties of hyaluronan receptors. J. Biol. Chem. 2002, 277, 4589-4592. [CrossRef] [PubMed]

186. Laurent, T.C.; Fraser, J.R.E. Hyaluronan 1. FASEB J. 1992, 6, 2397-2404. [CrossRef] [PubMed]

187. Collins, M.N.; Birkinshaw, C. Hyaluronic acid based scaffolds for tissue engineering-A review. Carbohydr. Polym. 2013, 92, 1262-1279. [CrossRef] [PubMed]

188. Hemshekhar, M.; Thushara, R.M.; Chandranayaka, S.; Sherman, L.S.; Kemparaju, K.; Girish, K.S. Emerging roles of hyaluronic acid bioscaffolds in tissue engineering and regenerative medicine. Int. J. Biol. Macromol. 2016, 86, 917-928. [CrossRef]

189. Jiao, Y.; Pang, X.; Zhai, G. Advances in hyaluronic acid-based drug delivery systems. Curr. Drug Targets 2016, 17, 720-730. [CrossRef]

190. Xu, X.; Jha, A.K.; Harrington, D.A.; Farach-Carson, M.C.; Jia, X. Hyaluronic acid-based hydrogels: From a natural polysaccharide to complex networks. Soft Matter 2012, 8, 3280-3294. [CrossRef]

191. Linde, A. A study of the dental pulp glycosaminoglycans from permanent human teeth and rat and rabbit incisors. Arch. Oral Biol. 1973, 18, 49-59. [CrossRef]

192. Felszeghy, S.; Hyttinen, M.; Tammi, R.; Tammi, M.; Módis, L. Quantitative image analysis of hyaluronan expression in human tooth germs. Eur. J. Oral Sci. 2000, 108, 320-326. [CrossRef] [PubMed]

193. Yang, R.; Tan, L.; Cen, L.; Zhang, Z. An injectable scaffold based on crosslinked hyaluronic acid gel for tissue regeneration. RSC Adv. 2016, 6, 16838-16850. [CrossRef]

194. Silva, C.R.; Babo, P.S.; Gulino, M.; Costa, L.; Oliveira, J.M.; Silva-Correia, J.; Domingues, R.M.; Reis, R.L.; Gomes, M.E. Injectable and tunable hyaluronic acid hydrogels releasing chemotactic and angiogenic growth factors for endodontic regeneration. Acta Biomater. 2018, 77, 155-171. [CrossRef]

195. Almeida, L.D.; Babo, P.S.; Silva, C.R.; Rodrigues, M.T.; Hebling, J.; Reis, R.L.; Gomes, M.E. Hyaluronic acid hydrogels incorporating platelet lysate enhance human pulp cell proliferation and differentiation. J. Mater. Sci. Mater. Med. 2018, 29, 88.

196. Niloy, K.K.; Gulfam, M.; Compton, K.B.; Li, D.; Huang, G.T.-J.; Lowe, T.L. Methacrylated Hyaluronic Acid-Based Hydrogels Maintain Stemness in Human Dental Pulp Stem Cells. Regen. Eng. Transl. Med. 2019, 6, 262-272. [CrossRef]

197. Zhu, X.; Liu, J.; Yu, Z.; Chen, C.-A.; Aksel, H.; Azim, A.A.; Huang, G.T.-J. A miniature swine model for stem cell-based de novo regeneration of dental pulp and dentin-like tissue. Tissue Eng. Part C Methods 2018, 24, 108-120. [CrossRef]

198. Chrepa, V.; Austah, O.; Diogenes, A. Evaluation of a commercially available hyaluronic acid hydrogel (Restylane) as injectable scaffold for dental pulp regeneration: An in vitro evaluation. J. Endod. 2017, 43, 257-262. [CrossRef]

199. Zucca, P.; Fernandez-Lafuente, R.; Sanjust, E. Agarose and its derivatives as supports for enzyme immobilization. Molecules 2016, 21, 1577. [CrossRef]

200. Prakash, O.; Jaiswal, N. Immobilization of a thermostable $\alpha$-amylase on agarose and agar matrices and its application in starch stain removal. World Appl. Sci. J. 2011, 13, 572-577.

201. Horinaka, J.-i.; Yasuda, R.; Takigawa, T. Entanglement network of agarose in various solvents. Polym. J. 2011, 43, 1000-1002. [CrossRef]

202. Wang, S.; Zhang, R.; Yang, Y.; Wu, S.; Cao, Y.; Lu, A.; Zhang, L. Strength enhanced hydrogels constructed from agarose in alkali/urea aqueous solution and their application. Chem. Eng. J. 2018, 331, 177-184. [CrossRef]

203. Christensen, L. Normal and pathologic tissue reactions to soft tissue gel fillers. Dermatol. Surg. 2007, 33, S168-S175. [PubMed]

204. Christensen, L.H. Host tissue interaction, fate, and risks of degradable and nondegradable gel fillers. Dermatol. Surg. 2009, 35, 1612-1619. [CrossRef]

205. Scarano, A.; Carinci, F.; Piattelli, A. Lip augmentation with a new filler (agarose gel): A 3-year follow-up study. Oral Surg. Oral Med. Oral Pathol. Oral Radiol. Endod. 2009, 108, e11-e15. [CrossRef] 
206. Cao, Z.; Gilbert, R.J.; He, W. Simple Agarose-Chitosan gel composite system for enhanced neuronal growth in three dimensions. Biomacromolecules 2009, 10, 2954-2959. [CrossRef]

207. Xiong, J.-Y.; Narayanan, J.; Liu, X.-Y.; Chong, T.K.; Chen, S.B.; Chung, T.-S. Topology evolution and gelation mechanism of agarose gel. J. Phys. Chem. B 2005, 109, 5638-5643. [CrossRef]

208. Zarrintaj, P.; Bakhshandeh, B.; Rezaeian, I.; Heshmatian, B.; Ganjali, M.R. A novel electroactive agarose-aniline pentamer platform as a potential candidate for neural tissue engineering. Sci. Rep. 2017, 7, 1-12. [CrossRef]

209. Campos, F.; Bonhome-Espinosa, A.B.; Vizcaino, G.; Rodriguez, I.A.; Durand-Herrera, D.; Lopez-Lopez, M.T.; Sánchez-Montesinos, I.; Alaminos, M.; Sánchez-Quevedo, M.C.; Carriel, V. Generation of genipin cross-linked fibrin-agarose hydrogel tissue-like models for tissue engineering applications. Biomed. Mater. 2018, 13, 025021. [CrossRef]

210. Sarem, M.; Moztarzadeh, F.; Mozafari, M. How can genipin assist gelatin/carbohydrate chitosan scaffolds to act as replacements of load-bearing soft tissues? Carbohydr. Polym. 2013, 93, 635-643. [CrossRef]

211. Cecilia, A.; Baecker, A.; Hamann, E.; Rack, A.; van de Kamp, T.; Gruhl, F.; Hofmann, R.; Moosmann, J.; Hahn, S.; Kashef, J. Optimizing structural and mechanical properties of cryogel scaffolds for use in prostate cancer cell culturing. Mater. Sci. Eng. C 2017, 71, 465-472. [CrossRef] [PubMed]

212. Park, K.M.; Lee, S.Y.; Joung, Y.K.; Na, J.S.; Lee, M.C.; Park, K.D. Thermosensitive chitosan-Pluronic hydrogel as an injectable cell delivery carrier for cartilage regeneration. Acta Biomater. 2009, 5, 1956-1965. [CrossRef] [PubMed]

213. El Moshy, S.; Abbass, M.M.; El-Motayam, A.M. Biomimetic remineralization of acid etched enamel using agarose hydrogel model. F1000Research 2018, 7, 1476. [CrossRef] [PubMed]

214. Cao, C.Y.; Li, Q.-L. Scanning electron microscopic analysis of using agarose hydrogel microenvironment to create enamel prism-like tissue on dentine surface. J. Dent. 2016, 55, 54-60. [CrossRef] [PubMed]

215. Chang, C.; Zhang, L. Cellulose-based hydrogels: Present status and application prospects. Carbohydr. Polym. 2011, 84, 40-53. [CrossRef]

216. Bourges, X.; Weiss, P.; Daculsi, G.; Legeay, G. Synthesis and general properties of silated-hydroxypropyl methylcellulose in prospect of biomedical use. Adv. Colloid Interface Sci. 2002, 99, 215-228. [CrossRef]

217. Guo, K.; Chu, C. Synthesis and characterization of novel biodegradable unsaturated poly (ester amide)/poly (ethylene glycol) diacrylate hydrogels. J. Polym. Sci. A Polym. Chem. 2005, 43, 3932-3944. [CrossRef]

218. Deng, J.; He, Q.; Wu, Z.; Yang, W. Using glycidyl methacrylate as cross-linking agent to prepare thermosensitive hydrogels by a novel one-step method. J. Polym. Sci. A Polym. Chem. 2008, 46, 2193-2201. [CrossRef]

219. Chen, H.; Fan, M. Novel thermally sensitive pH-dependent chitosan/carboxymethyl cellulose hydrogels. J. Polym. Sci. A Polym. Chem. 2008, 23, 38-48.

220. Chang, C.; Lue, A.; Zhang, L. Effects of crosslinking methods on structure and properties of cellulose/PVA hydrogels. Macromol. Chem. Phys. 2008, 209, 1266-1273. [CrossRef]

221. te Nijenhuis, K. On the nature of crosslinks in thermoreversible gels. Polym. Bull. 2007, 58, 27-42. [CrossRef]

222. Chen, C.-H.; Tsai, C.-C.; Chen, W.; Mi, F.-L.; Liang, H.-F.; Chen, S.-C.; Sung, H.-W. Novel living cell sheet harvest system composed of thermoreversible methylcellulose hydrogels. Biomacromolecules 2006, 7, 736-743. [CrossRef] [PubMed]

223. Vinatier, C.; Magne, D.; Weiss, P.; Trojani, C.; Rochet, N.; Carle, G.; Vignes-Colombeix, C.; Chadjichristos, C.; Galera, P.; Daculsi, G. A silanized hydroxypropyl methylcellulose hydrogel for the three-dimensional culture of chondrocytes. Biomaterials 2005, 26, 6643-6651. [CrossRef] [PubMed]

224. Vinatier, C.; Magne, D.; Moreau, A.; Gauthier, O.; Malard, O.; Vignes-Colombeix, C.; Daculsi, G.; Weiss, P.; Guicheux, J. Engineering cartilage with human nasal chondrocytes and a silanized hydroxypropyl methylcellulose hydrogel. J. Biomed. Mater. Res. A 2007, 80, 66-74. [CrossRef]

225. Trojani, C.; Weiss, P.; Michiels, J.-F.; Vinatier, C.; Guicheux, J.; Daculsi, G.; Gaudray, P.; Carle, G.F.; Rochet, N. Three-dimensional culture and differentiation of human osteogenic cells in an injectable hydroxypropylmethylcellulose hydrogel. Biomaterials 2005, 26, 5509-5517. [CrossRef]

226. Aubeux, D.; Beck, L.; Weiss, P.; Guicheux, J.; Enkel, B.; Pérez, F.; Simon, S. Assessment and quantification of noncollagenic matrix proteins released from human dentin powder incorporated into a silated hydroxypropylmethylcellulose biomedical hydrogel. J. Endod. 2016, 42, 1371-1376. [CrossRef]

227. Teti, G.; Salvatore, V.; Focaroli, S.; Durante, S.; Mazzotti, A.; Dicarlo, M.; Mattioli-Belmonte, M.; Orsini, G. In vitro osteogenic and odontogenic differentiation of human dental pulp stem cells seeded on carboxymethyl cellulose-hydroxyapatite hybrid hydrogel. Front. Physiol. 2015, 6, 297. [CrossRef] 
228. Iftikhar, S.; Zahid, S.; Safi, S.Z.; Khan, A.F.; Nawshad, M.; Ghafoor, S.; Khan, A.S.; Tufail, A. Smart injectable self-setting bioceramics for dental applications. Mater. Sci. Eng. C 2020, 113, 110956.

229. Badylak, S.F.; Lantz, G.C.; Coffey, A.; Geddes, L.A. Small intestinal submucosa as a large diameter vascular graft in the dog. J. Surg. Res. 1989, 47, 74-80. [CrossRef]

230. Lantz, G.C.; Badylak, S.F.; Coffey, A.C.; Geddes, L.A.; Blevins, W.E. Small intestinal submucosa as a small-diameter arterial graft in the dog. J. Investig. Surg. 1990, 3, 217-227. [CrossRef]

231. Lantz, G.C.; Badylak, S.F.; Coffey, A.C.; Geddes, L.A.; Sandusky, G.E. Small intestinal submucosa as a superior vena cava graft in the dog. J. Surg. Res. 1992, 53, 175-181. [CrossRef]

232. Sandusky Jr, G.; Badylak, S.; Morff, R.; Johnson, W.; Lantz, G. Histologic findings after in vivo placement of small intestine submucosal vascular grafts and saphenous vein grafts in the carotid artery in dogs. AJP 1992, $140,317$.

233. Lantz, G.C.; Badylak, S.F.; Hiles, M.C.; Coffey, A.C.; Geddes, L.A.; Kokini, K.; Sandusky, G.E.; Morff, R.J. Small intestinal submucosa as a vascular graft: A review. J. Investig. Surg. 1993, 6, 297-310. [CrossRef]

234. Voytik-Harbin, S.L.; Brightman, A.O.; Waisner, B.Z.; Robinson, J.P.; Lamar, C.H. Small intestinal submucosa: A tissue-derived extracellular matrix that promotes tissue-specific growth and differentiation of cells in vitro. Tissue Eng. 1998, 4, 157-174. [CrossRef]

235. Badylak, S.F.; Freytes, D.O.; Gilbert, T.W. Extracellular matrix as a biological scaffold material: Structure and function. Acta Biomater. 2009, 5, 1-13. [CrossRef]

236. Zantop, T.; Gilbert, T.W.; Yoder, M.C.; Badylak, S.F. Extracellular matrix scaffolds are repopulated by bone marrow-derived cells in a mouse model of achilles tendon reconstruction. J. Orthop. Res. 2006, 24, 1299-1309. [CrossRef]

237. Drake, M.; Davison, P.; Bump, S.; Schmitt, F. Action of proteolytic enzymes on tropocollagen and insoluble collagen. Biochemistry 1966, 5, 301-312. [CrossRef]

238. Miller, E. Structural studies on cartilage collagen employing limited cleavage and solubilization with pepsin. Biochemistry 1972, 11, 4903-4909. [CrossRef]

239. Uriel, S.; Labay, E.; Francis-Sedlak, M.; Moya, M.L.; Weichselbaum, R.R.; Ervin, N.; Cankova, Z.; Brey, E.M. Extraction and assembly of tissue-derived gels for cell culture and tissue engineering. Tissue Eng. Part C Methods 2009, 15, 309-321. [CrossRef]

240. Cheng, M.H.; Uriel, S.; Moya, M.L.; Francis-Sedlak, M.; Wang, R.; Huang, J.J.; Chang, S.Y.; Brey, E.M. Dermis-derived hydrogels support adipogenesis in vivo. J. Biomed. Mater. Res. A 2010, 92, 852-858.

241. Pilipchuk, S.P.; Vaicik, M.K.; Larson, J.C.; Gazyakan, E.; Cheng, M.H.; Brey, E.M. Influence of crosslinking on the stiffness and degradation of dermis-derived hydrogels. J. Biomed. Mater. Res. A 2013, 101, 2883-2895. [CrossRef]

242. Poon, C.J.; Cotta, M.V.P.E.; Sinha, S.; Palmer, J.A.; Woods, A.A.; Morrison, W.A.; Abberton, K.M. Preparation of an adipogenic hydrogel from subcutaneous adipose tissue. Acta Biomater. 2013, 9, 5609-5620. [CrossRef]

243. Freytes, D.O.; Martin, J.; Velankar, S.S.; Lee, A.S.; Badylak, S.F. Preparation and rheological characterization of a gel form of the porcine urinary bladder matrix. Biomaterials 2008, 29, 1630-1637. [CrossRef]

244. Saldin, L.T.; Cramer, M.C.; Velankar, S.S.; White, L.J.; Badylak, S.F. Extracellular matrix hydrogels from decellularized tissues: Structure and function. Acta Biomater. 2017, 49, 1-15. [CrossRef]

245. Wang, Y.; Chatzistavrou, X.; Faulk, D.; Badylak, S.; Zheng, L.; Papagerakis, S.; Ge, L.; Liu, H.; Papagerakis, P. Biological and bactericidal properties of Ag-doped bioactive glass in a natural extracellular matrix hydrogel with potential application in dentistry. Eur. Cell Mater. 2015, 29, 342-355. [CrossRef]

246. Chatzistavrou, X.; Fenno, J.C.; Faulk, D.; Badylak, S.; Kasuga, T.; Boccaccini, A.R.; Papagerakis, P. Fabrication and characterization of bioactive and antibacterial composites for dental applications. Acta Biomater. 2014, 10, 3723-3732. [CrossRef]

247. Li, J.; Rao, Z.; Zhao, Y.; Xu, Y.; Chen, L.; Shen, Z.; Bai, Y.; Lin, Z.; Huang, Q. A Decellularized Matrix Hydrogel Derived from Human Dental Pulp Promotes Dental Pulp Stem Cell Proliferation, Migration, and Induced Multidirectional Differentiation In Vitro. J. Endod. 2020. [CrossRef]

248. Holiel, A.A.; Mahmoud, E.M.; Abdel-Fattah, W.M.; Kawana, K.Y. Histological evaluation of the regenerative potential of a novel treated dentin matrix hydrogel in direct pulp capping. Clin. Oral Investig. 2020, 1-12. [CrossRef] 
249. Meza, G.; Urrejola, D.; Saint Jean, N.; Inostroza, C.; López, V.; Khoury, M.; Brizuela, C. Personalized Cell Therapy for Pulpitis Using Autologous Dental Pulp Stem Cells and Leukocyte Platelet-rich Fibrin: A Case Report. J. Endod. 2019, 45, 144-149. [CrossRef]

250. Mittal, N.; Parashar, V. Regenerative Evaluation of Immature Roots using PRF and Artificial Scaffolds in Necrotic Permanent Teeth: A Clinical Study. JCDP 2019, 20, 720-726. [CrossRef]

251. Garnica-Palafox, I.M.; Sánchez-Arévalo, F.M. Influence of natural and synthetic crosslinking reagents on the structural and mechanical properties of chitosan-based hybrid hydrogels. Carbohydr. Polym. 2016, 151, 1073-1081. [CrossRef]

252. Munim, S.A.; Raza, Z.A. Poly(lactic acid) based hydrogels: Formation, characteristics and biomedical applications. J. Porous Mater. 2019, 26, 881-901. [CrossRef]

253. Gibas, I.; Janik, H. Review: Synthetic polymer hydrogels for biomedical applications. Chem. Chem. Technol 2010, 4, 297-304.

254. Böstman, O.M.; Pihlajamäki, H.K. Adverse tissue reactions to bioabsorbable fixation devices. Clin. Orthop. Relat. Res. 2000, 371, 216-227. [CrossRef]

255. Basu, A.; Kunduru, K.R.; Doppalapudi, S.; Domb, A.J.; Khan, W. Poly(lactic acid) based hydrogels. Adv. Drug Del. Rev. 2016, 107, 192-205. [CrossRef]

256. Tsuji, H. Poly(Lactic Acid). In Bio-Based Plastics; Kabasci, S., Ed.; Wiley Online Books: Hoboken, NJ, USA, 2013; pp. 171-239. [CrossRef]

257. Kuang, R.; Zhang, Z.; Jin, X.; Hu, J.; Gupte, M.J.; Ni, L.; Ma, P.X. Nanofibrous Spongy Microspheres Enhance Odontogenic Differentiation of Human Dental Pulp Stem Cells. Adv. Healthc. Mater. 2015, 4, 1993-2000. [CrossRef] [PubMed]

258. Zou, H.; Wang, G.; Song, F.; Shi, X. Investigation of human dental pulp cells on a potential injectable poly (lactic-co-glycolic acid) microsphere scaffold. J. Endod. 2017, 43, 745-750. [CrossRef]

259. Jeong, B.; Bae, Y.H.; Lee, D.S.; Kim, S.W. Biodegradable block copolymers as injectable drug-delivery systems. Nature 1997, 388, 860-862. [CrossRef]

260. Shiehzadeh, V.; Aghmasheh, F.; Shiehzadeh, F.; Joulae, M.; Kosarieh, E.; Shiehzadeh, F. Healing of large periapical lesions following delivery of dental stem cells with an injectable scaffold: New method and three case reports. Indian J. Dent. Res. 2014, 25, 248. [CrossRef]

261. Stringer, D. Linear polydimethylsiloxanes:(Viscosity 10-10,000 Centistokes): CAS; European Centre for Ecotoxicology and Toxicology of Chemicals: Brussels, Belgium, 1994.

262. Zhu, J.; Marchant, R.E. Design properties of hydrogel tissue-engineering scaffolds. Expert Rev. Med. Devices 2011, 8, 607-626. [CrossRef] [PubMed]

263. Liu, N.; Zhou, M.; Zhang, Q.; Zhang, T.; Tian, T.; Ma, Q.; Xue, C.; Lin, S.; Cai, X. Stiffness regulates the proliferation and osteogenic/odontogenic differentiation of human dental pulp stem cells via the WNT signalling pathway. Cell Prolif. 2018, 51, e12435. [CrossRef] [PubMed]

264. Cai, X.; Xie, J.; Yao, Y.; Cun, X.; Lin, S.; Tian, T.; Zhu, B.; Lin, Y. The role of WNT Signaling in engineering functional vascular networks for tissue regeneration. Bone Res. 2017, 5, 17048. [CrossRef] [PubMed]

265. Tao, K.; Xiao, D.; Weng, J.; Xiong, A.; Kang, B.; Zeng, H. Berberine promotes bone marrow-derived mesenchymal stem cells osteogenic differentiation via canonical Wnt/ $\beta$-catenin signaling pathway. Toxicol. Lett. 2016, 240, 68-80. [CrossRef] [PubMed]

266. Hunter, D.J.; Bardet, C.; Mouraret, S.; Liu, B.; Singh, G.; Sadoine, J.; Dhamdhere, G.; Smith, A.; Tran, X.V.; Joy, A. Wnt acts as a prosurvival signal to enhance dentin regeneration. JBMR 2015, 30, 1150-1159. [CrossRef] [PubMed]

267. Itoh, Y.; Sasaki, J.; Hashimoto, M.; Katata, C.; Hayashi, M.; Imazato, S. Pulp regeneration by 3-dimensional dental pulp stem cell constructs. J. Dent. Res. 2018, 97, 1137-1143. [CrossRef]

268. Mano, J.F. Stimuli-responsive polymeric systems for biomedical applications. Adv. Eng. Mater 2008, 10, 515-527. [CrossRef]

269. Yoshida, R.; Okano, T. Stimuli-responsive hydrogels and their application to functional materials. In Biomedical Applications of Hydrogels Handbook; Ottenbrite, R.M., Park, K., Okano, T., Eds.; Springer Science \& Business Media: New York, NY, USA, 2010; pp. 19-43.

270. Graham, L.; Cooper, P.R.; Cassidy, N.; Nor, J.E.; Sloan, A.J.; Smith, A.J. The effect of calcium hydroxide on solubilisation of bio-active dentine matrix components. Biomaterials 2006, 27, 2865-2873. [CrossRef] 
271. Buxton, A.N.; Zhu, J.; Marchant, R.; West, J.L.; Yoo, J.U.; Johnstone, B. Design and characterization of poly (ethylene glycol) photopolymerizable semi-interpenetrating networks for chondrogenesis of human mesenchymal stem cells. Tissue Eng. 2007, 13, 2549-2560. [CrossRef] 
272. Beamish, J.A.; Zhu, J.; Kottke-Marchant, K.; Marchant, R.E. The effects of monoacrylated poly (ethylene glycol) on the properties of poly (ethylene glycol) diacrylate hydrogels used for tissue engineering. J. Biomed. Mater. Res. A 2010, 92, 441-450. [CrossRef]

273. Yang, F.; Williams, C.G.; Wang, D.-A.; Lee, H.; Manson, P.N.; Elisseeff, J. The effect of incorporating RGD adhesive peptide in polyethylene glycol diacrylate hydrogel on osteogenesis of bone marrow stromal cells. Biomaterials 2005, 26, 5991-5998. [CrossRef]

274. Gyawali, D.; Nair, P.; Zhang, Y.; Tran, R.T.; Zhang, C.; Samchukov, M.; Makarov, M.; Kim, H.K.; Yang, J. Citric acid-derived in situ crosslinkable biodegradable polymers for cell delivery. Biomaterials 2010, 31, 9092-9105. [CrossRef] [PubMed]

275. Komabayashi, T.; Wadajkar, A.; Santimano, S.; Ahn, C.; Zhu, Q.; Opperman, L.A.; Bellinger, L.L.; Yang, J.; Nguyen, K.T. Preliminary study of light-cured hydrogel for endodontic drug delivery vehicle. J. Investig. Clin. Dent. 2016, 7, 87-92. [CrossRef] [PubMed]

276. Dissanayaka, W.L.; Hargreaves, K.M.; Jin, L.; Samaranayake, L.P.; Zhang, C. The interplay of dental pulp stem cells and endothelial cells in an injectable peptide hydrogel on angiogenesis and pulp regeneration in vivo. Tissue Eng. Part A 2015, 21, 550-563. [CrossRef] [PubMed]

277. Cui, H.; Webber, M.J.; Stupp, S.I. Self-assembly of peptide amphiphiles: From molecules to nanostructures to biomaterials. Biopolymers 2010, 94, 1-18. [CrossRef] [PubMed]

278. Jonker, A.M.; Löwik, D.W.; van Hest, J.C. Peptide-and protein-based hydrogels. Chem. Mater. 2012, 24, 759-773. [CrossRef]

279. Rivas, M.; Del Valle, L.J.; Alemán, C.; Puiggalí, J. Peptide self-assembly into hydrogels for biomedical applications related to hydroxyapatite. Gels 2019, 5, 14. [CrossRef] [PubMed]

280. Huang, C.; Bao, L.; Lin, T.; Lu, Y.; Wu, Y. Proliferation and odontogenic differentiation of human umbilical cord mesenchymal stem cells and human dental pulp cells co-cultured in hydrogel. Arch. Oral Biol. 2020, 109, 104582. [CrossRef]

281. Yokoi, H.; Kinoshita, T.; Zhang, S. Dynamic reassembly of peptide RADA16 nanofiber scaffold. Proc. Natl. Acad. Sci. USA 2005, 102, 8414-8419. [CrossRef]

282. Narmoneva, D.A.; Oni, O.; Sieminski, A.L.; Zhang, S.; Gertler, J.P.; Kamm, R.D.; Lee, R.T. Self-assembling short oligopeptides and the promotion of angiogenesis. Biomaterials 2005, 26, 4837-4846. [CrossRef]

283. Thonhoff, J.R.; Lou, D.I.; Jordan, P.M.; Zhao, X.; Wu, P. Compatibility of human fetal neural stem cells with hydrogel biomaterials in vitro. Brain Res. 2008, 1187, 42-51. [CrossRef]

284. Davis, M.E.; Hsieh, P.C.; Takahashi, T.; Song, Q.; Zhang, S.; Kamm, R.D.; Grodzinsky, A.J.; Anversa, P.; Lee, R.T. Local myocardial insulin-like growth factor 1 (IGF-1) delivery with biotinylated peptide nanofibers improves cell therapy for myocardial infarction. Proc. Natl. Acad. Sci. USA 2006, 103, 8155-8160. [CrossRef] [PubMed]

285. Segers, V.F.M.; Tokunou, T.; Higgins, L.J.; MacGillivray, C.; Gannon, J.; Lee, R.T. Local delivery of protease-resistant stromal cell derived factor-1 for stem cell recruitment after myocardial infarction. Circulation 2007, 116, 1683-1692. [CrossRef] [PubMed]

286. Davis, M.E.; Motion, J.M.; Narmoneva, D.A.; Takahashi, T.; Hakuno, D.; Kamm, R.D.; Zhang, S.; Lee, R.T. Injectable self-assembling peptide nanofibers create intramyocardial microenvironments for endothelial cells. Circulation 2005, 111, 442-450. [CrossRef] [PubMed]

287. Hsieh, P.C.; Davis, M.E.; Gannon, J.; MacGillivray, C.; Lee, R.T. Controlled delivery of PDGF-BB for myocardial protection using injectable self-assembling peptide nanofibers. J. Clin. Investig. 2006, 116, 237-248. [CrossRef] [PubMed]

288. Semino, C.E.; Kasahara, J.; Hayashi, Y.; Zhang, S. Entrapment of migrating hippocampal neural cells in three-dimensional peptide nanofiber scaffold. Tissue Eng. 2004, 10, 643-655. [CrossRef] [PubMed]

289. Wang, S.; Nagrath, D.; Chen, P.C.; Berthiaume, F.; Yarmush, M.L. Three-dimensional primary hepatocyte culture in synthetic self-assembling peptide hydrogel. Tissue Eng. Part A. 2008, 14, 227-236. [CrossRef] [PubMed] 
290. Misawa, H.; Kobayashi, N.; Soto-Gutierrez, A.; Chen, Y.; Yoshida, A.; Rivas-Carrillo, J.D.; Navarro-Alvarez, N.; Tanaka, K.; Miki, A.; Takei, J. PuraMatrix ${ }^{\mathrm{TM}}$ facilitates bone regeneration in bone defects of calvaria in mice. Cell Transplant. 2006, 15, 903-910. [CrossRef]

291. Cavalcanti, B.N.; Zeitlin, B.D.; Nör, J.E. A hydrogel scaffold that maintains viability and supports differentiation of dental pulp stem cells. Dent. Mater. 2013, 29, 97-102. [CrossRef]

292. Sakai, V.; Zhang, Z.; Dong, Z.; Neiva, K.; Machado, M.; Shi, S.; Santos, C.; Nör, J. SHED differentiate into functional odontoblasts and endothelium. J. Dent. Res. 2010, 89, 791-796. [CrossRef]

293. Dissanayaka, W.L.; Zhu, L.; Hargreaves, K.M.; Jin, L.; Zhang, C. In vitro analysis of scaffold-free prevascularized microtissue spheroids containing human dental pulp cells and endothelial cells. J. Endod. 2015, 41, 663-670. [CrossRef]

294. Rombouts, C.; Giraud, T.; Jeanneau, C.; About, I. Pulp vascularization during tooth development, regeneration, and therapy. J. Dent. Res. 2017, 96, 137-144. [CrossRef] [PubMed]

295. Zentilin, L.; Tafuro, S.; Zacchigna, S.; Arsic, N.; Pattarini, L.; Sinigaglia, M.; Giacca, M. Bone marrow mononuclear cells are recruited to the sites of VEGF-induced neovascularization but are not incorporated into the newly formed vessels. Blood 2006, 107, 3546-3554. [CrossRef] [PubMed]

296. Carmeliet, P. VEGF gene therapy: Stimulating angiogenesis or angioma-genesis? Nat. Med. 2000, 6, 1102-1103. [CrossRef] [PubMed]

297. Marsboom, G.; Pokreisz, P.; Gheysens, O.; Vermeersch, P.; Gillijns, H.; Pellens, M.; Liu, X.; Collen, D.; Janssens, S. Sustained endothelial progenitor cell dysfunction after chronic hypoxia-induced pulmonary hypertension. Stem. Cells 2008, 26, 1017-1026. [CrossRef] [PubMed]

298. Das, R.; Jahr, H.; van Osch, G.J.; Farrell, E. The role of hypoxia in bone marrow-derived mesenchymal stem cells: Considerations for regenerative medicine approaches. Tissue Eng. Part B Rev. 2010, 16, 159-168. [CrossRef]

299. Grunewald, M.; Avraham, I.; Dor, Y.; Bachar-Lustig, E.; Itin, A.; Yung, S.; Chimenti, S.; Landsman, L.; Abramovitch, R.; Keshet, E. VEGF-induced adult neovascularization: Recruitment, retention, and role of accessory cells. Cell 2006, 124, 175-189. [CrossRef]

300. Cordeiro, M.M.; Dong, Z.; Kaneko, T.; Zhang, Z.; Miyazawa, M.; Shi, S.; Smith, A.J.; Nör, J.E. Dental pulp tissue engineering with stem cells from exfoliated deciduous teeth. J. Endod. 2008, 34, 962-969. [CrossRef]

301. Rouwkema, J.; Rivron, N.C.; van Blitterswijk, C.A. Vascularization in tissue engineering. Trends Biotechnol. 2008, 26, 434-441. [CrossRef]

302. Rouwkema, J.; Boer, J.D.; Blitterswijk, C.A.V. Endothelial cells assemble into a 3-dimensional prevascular network in a bone tissue engineering construct. Tissue Eng. 2006, 12, 2685-2693. [CrossRef]

303. Kelm, J.M.; Djonov, V.; Ittner, L.M.; Fluri, D.; Born, W.; Hoerstrup, S.P.; Fussenegger, M. Design of custom-shaped vascularized tissues using microtissue spheroids as minimal building units. Tissue Eng. 2006, 12, 2151-2160. [CrossRef]

304. Dong, H.; Paramonov, S.E.; Aulisa, L.; Bakota, E.L.; Hartgerink, J.D. Self-assembly of multidomain peptides: Balancing molecular frustration controls conformation and nanostructure. J. Am. Chem. Soc. 2007, 129, 12468-12472. [CrossRef]

305. Ferrara, N. Role of vascular endothelial growth factor in physiologic and pathologic angiogenesis: Therapeutic implications. Semin. Oncol. 2002, 29, 10-14. [CrossRef] [PubMed]

306. Shimabukuro, Y.; Ueda, M.; Ozasa, M.; Anzai, J.; Takedachi, M.; Yanagita, M.; Ito, M.; Hashikawa, T.; Yamada, S.; Murakami, S. Fibroblast growth factor-2 regulates the cell function of human dental pulp cells. J. Endod. 2009, 35, 1529-1535. [CrossRef] [PubMed]

307. Jia, X.; Kiick, K.L. Hybrid multicomponent hydrogels for tissue engineering. Macromol. Biosci. 2009, 9, 140-156. [CrossRef] [PubMed]

308. Lin, C.-C.; Metters, A.T. Hydrogels in controlled release formulations: Network design and mathematical modeling. Adv. Drug Del. Rev. 2006, 58, 1379-1408. [CrossRef] [PubMed]

309. Slaughter, B.V.; Khurshid, S.S.; Fisher, O.Z.; Khademhosseini, A.; Peppas, N.A. Hydrogels in regenerative medicine. Adv. Mater. 2009, 21, 3307-3329. [CrossRef] 
310. Shin, S.R.; Jung, S.M.; Zalabany, M.; Kim, K.; Zorlutuna, P.; Kim, S.b.; Nikkhah, M.; Khabiry, M.; Azize, M.; Kong, J. Carbon-nanotube-embedded hydrogel sheets for engineering cardiac constructs and bioactuators. ACS Nano 2013, 7, 2369-2380. [CrossRef]

311. Xavier, J.R.; Thakur, T.; Desai, P.; Jaiswal, M.K.; Sears, N.; Cosgriff-Hernandez, E.; Kaunas, R.; Gaharwar, A.K. Bioactive nanoengineered hydrogels for bone tissue engineering: A growth-factor-free approach. ACS Nano 2015, 9, 3109-3118. [CrossRef]

312. Feng, S.; Liu, J.; Ramalingam, M. 3D Printing of Stem Cell Responsive Ionically-Crosslinked Polyethylene Glycol Diacrylate/Alginate Composite Hydrogels Loaded with Basic Fibroblast Growth Factor for Dental Pulp Tissue Engineering: A Preclinical Evaluation in Animal Model. J. Biomater. Tissue Eng. 2020, 9, 1635-1643. [CrossRef]

313. Lu, Q.; Pandya, M.; Rufaihah, A.J.; Rosa, V.; Tong, H.J.; Seliktar, D.; Toh, W.S. Modulation of dental pulp stem cell odontogenesis in a tunable PEG-fibrinogen hydrogel system. Stem Cells Int. 2015, 2015, 525367. [CrossRef]

314. Jones, T.; Kefi, A.; Sun, S.; Cho, M.; Alapati, S. An optimized injectable hydrogel scaffold supports human dental pulp stem cell viability and spreading. Adv. Med. 2016, 2016, 7363579. [CrossRef] [PubMed]

315. Prestwich, G.D. Hyaluronic acid-based clinical biomaterials derived for cell and molecule delivery in regenerative medicine. JCR 2011, 155, 193-199. [CrossRef] [PubMed]

316. Sumita, Y.; Honda, M.J.; Ohara, T.; Tsuchiya, S.; Sagara, H.; Kagami, H.; Ueda, M. Performance of collagen sponge as a 3-D scaffold for tooth-tissue engineering. Biomaterials 2006, 27, 3238-3248. [CrossRef] [PubMed]

317. Radice, M.; Brun, P.; Cortivo, R.; Scapinelli, R.; Battaliard, C.; Abatangelo, G. Hyaluronan-based biopolymers as delivery vehicles for bone-marrow-derived mesenchymal progenitors. J. Biomed. Mater. Res. 2000, 50, 101-109. [CrossRef]

318. Tibbitt, M.W.; Anseth, K.S. Hydrogels as extracellular matrix mimics for 3D cell culture. Biotechnol. Bioeng. 2009, 103, 655-663. [CrossRef]

319. Toh, W.S.; Loh, X.J. Advances in hydrogel delivery systems for tissue regeneration. Mater. Sci. Eng. C 2014, 45, 690-697. [CrossRef]

320. Liu, L.; Kuffová, L.; Griffith, M.; Dang, Z.; Muckersie, E.; Liu, Y.; McLaughlin, C.R.; Forrester, J.V. Immunological responses in mice to full-thickness corneal grafts engineered from porcine collagen. Biomaterials 2007, 28, 3807-3814. [CrossRef]

321. Chirani, N.; Gritsch, L.; Motta, F.L.; Fare, S. History and applications of hydrogels. J. Biomed. Sci. 2015, 4, $1-23$.

322. Varghese, S.; Elisseeff, J.H. Hydrogels for Musculoskeletal Tissue Engineering. In Polymers for Regenerative Medicine; Werner, C., Ed.; Springer: Berlin/Heidelberg, Germany, 2006; pp. 95-144. [CrossRef]

323. Caliari, S.R.; Burdick, J.A. A practical guide to hydrogels for cell culture. Nat. Methods 2016, 13, $405-414$. [CrossRef]

324. Guvendiren, M.; Burdick, J.A. Engineering synthetic hydrogel microenvironments to instruct stem cells. Curr. Opin. Biotechnol. 2013, 24, 841-846. [CrossRef]

325. Galler, K.M.; Brandl, F.P.; Kirchhof, S.; Widbiller, M.; Eidt, A.; Buchalla, W.; Goepferich, A.; Schmalz, G. Suitability of different natural and synthetic biomaterials for dental pulp tissue engineering. Tissue Eng. Part A. 2018, 24, 234-244. [CrossRef]

326. Del Amo, C.; Perez-Valle, A.; Perez-Zabala, E.; Perez-del-Pecho, K.; Larrazabal, A.; Basterretxea, A.; Bully, P.; Andia, I. Wound Dressing Selection Is Critical to Enhance Platelet-Rich Fibrin Activities in Wound Care. Int. J. Mol. Sci. 2020, 21, 624. [CrossRef] [PubMed]

327. Janmey, P.A.; Winer, J.P.; Weisel, J.W. Fibrin gels and their clinical and bioengineering applications. J. R. Soc. Interface 2009, 6, 1-10. [CrossRef] [PubMed]

328. Zhang, T.; Gong, T.; Xie, J.; Lin, S.; Liu, Y.; Zhou, T.; Lin, Y. Softening Substrates Promote Chondrocytes Phenotype via RhoA/ROCK Pathway. ACS Appl. Mater. Interfaces 2016, 8, 22884-22891. [CrossRef]

329. Rony, R. Transcriptional Characterization of Osteogenic and Adipogenic Differentiation of human Bone Marrow Derived Mesenchymal Stem Cells in 2D and 3D Peptide Hydrogel Culture System. Ph.D. Thesis, Wright State University, Dayton, OH, USA, 2018.

330. Casagrande, L.; Demarco, F.; Zhang, Z.; Araujo, F.; Shi, S.; Nör, J. Dentin-derived BMP-2 and odontoblast differentiation of SHED. J. Dent. Res. 2010, 89, 603-608. [CrossRef] [PubMed] 
331. Miller, C.C.; Septier, D.; Bonnefoix, M.; Lecolle, S.; Lebreton-Decoster, C.; Coulomb, B.; Pellat, B.; Godeau, G. Human dermal and gingival fibroblasts in a three-dimensional culture: A comparative study on matrix remodeling. Clin. Oral Investig. 2002, 6, 39-50. [CrossRef]

332. Smith, J.; Smith, A.; Shelton, R.; Cooper, P. Recruitment of dental pulp cells by dentine and pulp extracellular matrix components. Exp. Cell Res. 2012, 318, 2397-2406. [CrossRef]

Publisher's Note: MDPI stays neutral with regard to jurisdictional claims in published maps and institutional affiliations.

(C) 2020 by the authors. Licensee MDPI, Basel, Switzerland. This article is an open access article distributed under the terms and conditions of the Creative Commons Attribution (CC BY) license (http://creativecommons.org/licenses/by/4.0/). 